\title{
ESTIMATION OF PIER SCOUR AND CHANNEL STABILITY FOR HIGHWAY CROSSINGS OF THE RED RIVER IN LOUISIANA
}

By J. Josh Gilbert and Paul A. Ensminger

U.S. GEOLOGICAL SURVEY

Open-File Report 96-574

Prepared in cooperation with the:

LOUISIANA DEPARTMENT OF TRANSPORTATION AND DEVELOPMENT

Baton Rouge, Louisiana 


\section{U.S. DEPARTMENT OF THE INTERIOR \\ BRUCE BABBITT, SECRETARY}

\section{U.S. GEOLOGICAL SURVEY}

Gordon P. Eaton, Director

For additional information write to:

District Chief U.S. Geological Survey 3535 S. Sherwood Forest Blvd., Suite 120 Baton Rouge, LA 70816 E-mail: dc_la@usgs.gov Telephone: (504) 389-0281
Copies of this report can be purchased from:

U.S. Geological Survey

Branch of Information Services

Box 25286

Denver, CO 80225-0286 


\section{CONTENTS}

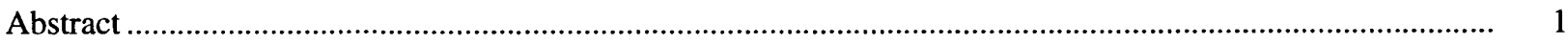

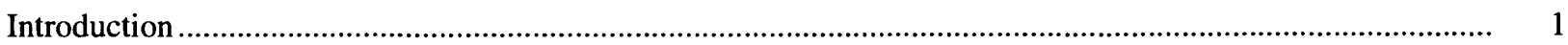

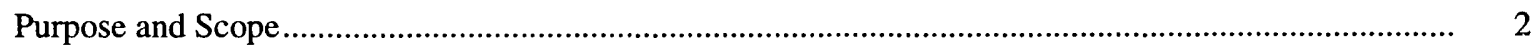

Description of Study Area .......................................................................................................... 2

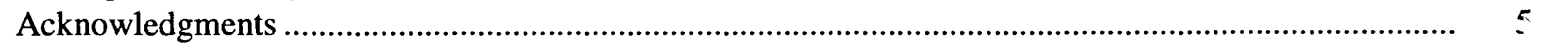

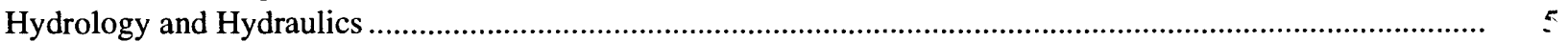

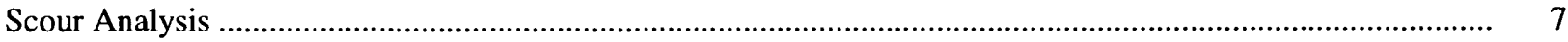

Channel Stability ……................................................................................................................... 7

Contraction and Abutment Scour .......................................................................................................... 7

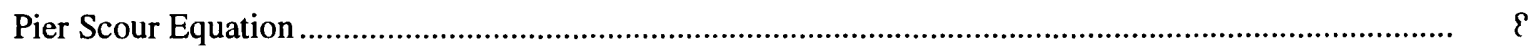

Highway Crossings of the Red River in Louisiana ...................................................................................... $\varepsilon$

Louisiana Highway 107 near Moncla, Louisiana .............................................................................

Pier Scour.................

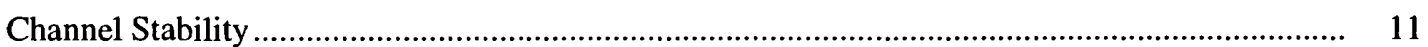

U.S. Highways 167, 165, and 71 at Alexandria, Louisiana.......................................................... 14

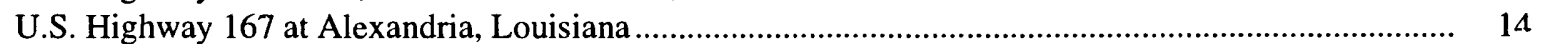

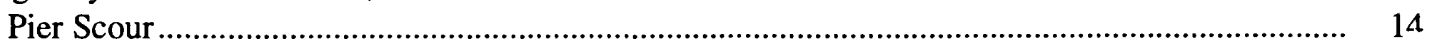

Channel Stability .............................................................................................................. 14

U.S. Highway 167 (Proposed) at Alexandria, Louisiana .................................................................... 17

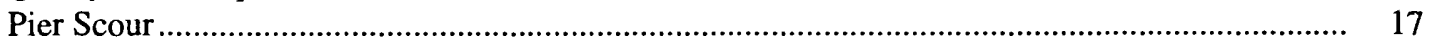

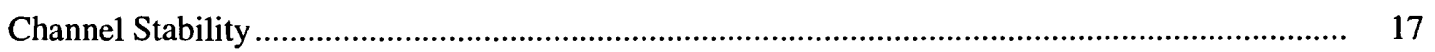

U.S. Highway 165 at Alexandria, Louisiana ..................................................................................... 17

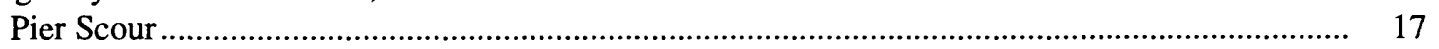

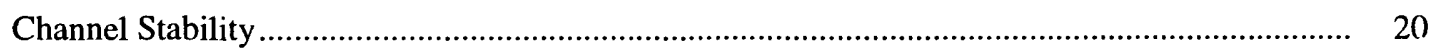

U.S. Highway 71 at Alexandria, Louisiana ......................................................................... 20

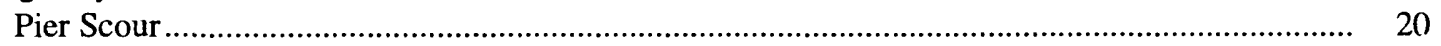

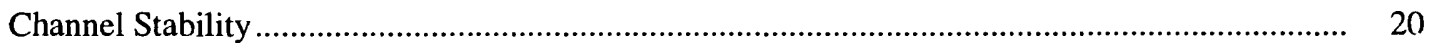

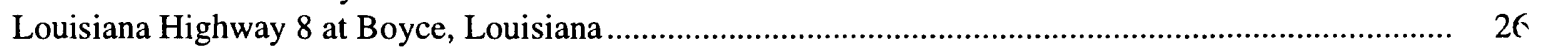

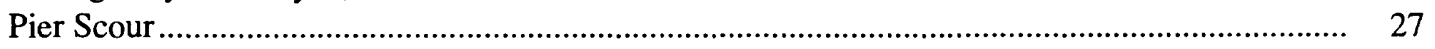

Channel Stability ....................................................................................................... 27

Louisiana Highway 6 at Grand Ecore, Louisiana............................................................................. 27

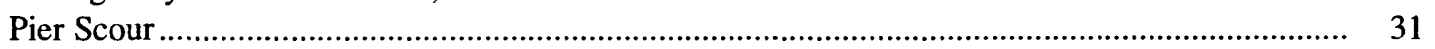

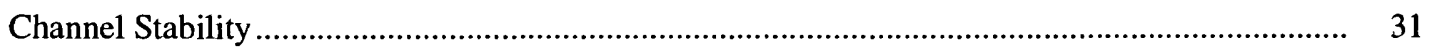

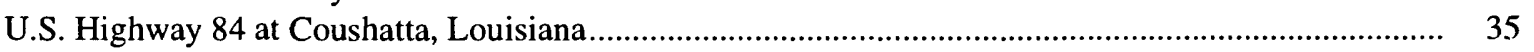

Pier Scour ...................................................................................................................... 35

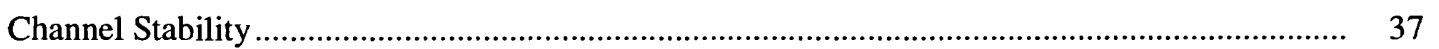

Louisiana Highways 511 and 3032, Interstate Highway 20, and U.S. Highway 80 at Shreveport,

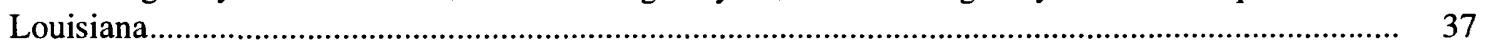

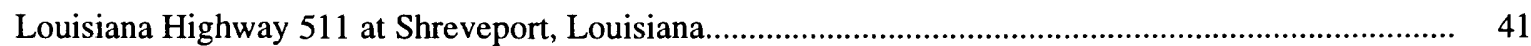

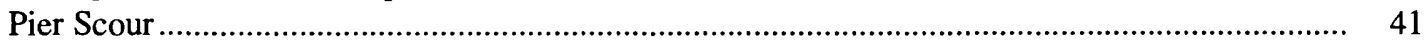

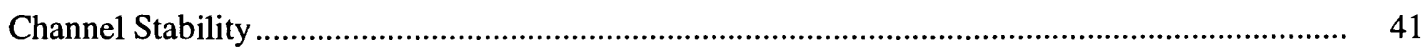

Louisiana Highway 3032 at Shreveport, Louisiana.............................................................................. 41

Pier Scour ......................................................................................................... 41

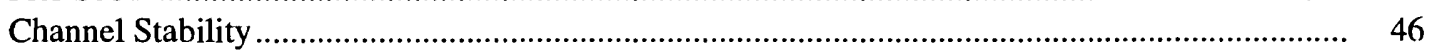

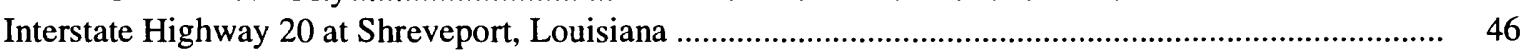

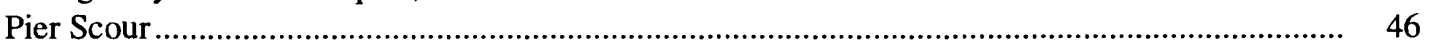

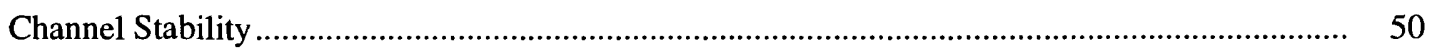

U.S. Highway 80 at Shreveport, Louisiana .............................................................................. 50

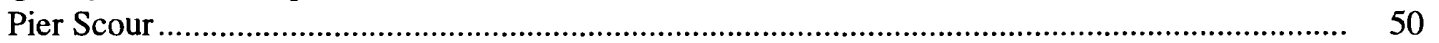

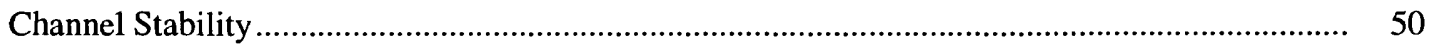

Interstate Highway 220 at Shreveport, Louisiana .................................................................... 56

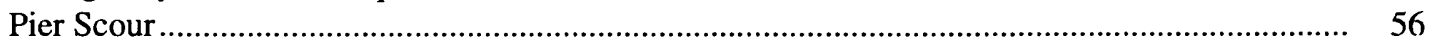




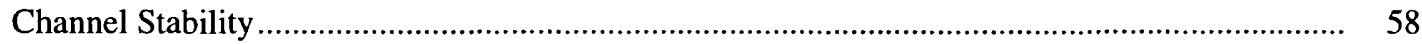

Louisiana Highway 2 near Hosston, Louisiana ..................................................................... 58

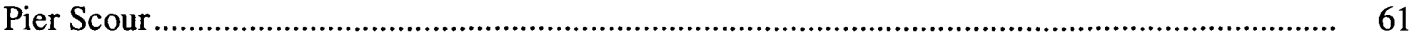

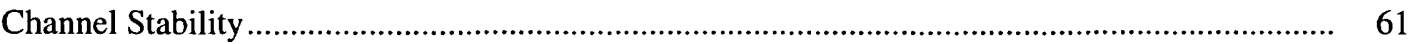

Conclusions

Selected References

\section{FIGURES}

1. Location of highway crossings along the Red River, Louisiana .

2. Location of highway crossings evaluated in the vicinity of Shreveport, Louisiana .................................

3. The 500-year flood estimates on the Red River from Fulton, Arkansas, to Alexandria, Louisiana........ 6

4. Comparative cross sections and pier-scour estimates at Louisiana Highway 107 near Moncla, Louisiana.

5. Aerial photograph of the Louisiana Highway 107 crossing of the Red River near Moncla, Louisiana, October 5, 1987

6. Aerial photograph of the Louisiana Highway 107 crossing of the Red River near Moncla, Louisiana, November 1, 1988 .

7. Comparative cross sections and pier-scour estimates at U.S. Highway 167 crossing at Alexandria, Louisiana.

8. Comparative cross sections and pier-scour estimates at proposed Louisiana Highway 167 crossing at Alexandria, Louisiana......

9. Comparative cross sections and pier-scour estimates at U.S. Highway 165 crossing at Alexandria, Louisiana

10. Aerial photograph of the U.S. Highways 165 and 167 crossings of the Red River at Alexandria, Louisiana, August 8, 1977.

11. Aerial photograph of the U.S. Highways 165 and 167 crossings of the Red River at Alexandria, Louisiana, October 5, 1987.

12. Comparative cross sections and pier-scour estimates at U.S. Highway 71 crossing at Alexandria, Louisiana.

13. Aerial photograph of the U.S. Highway 71 crossing of the Red River at Alexandria, Louisiana, August 8, 1977.

14. Aerial photograph of the U.S. Highway 71 crossing of the Red River at Alexandria, Louisiana, October 5, 1987.

15. Comparative cross sections and pier-scour estimates at Louisiana Highway 8 crossing at Boyce, Louisiana.

16. Aerial photograph of the Louisiana Highway 8 crossing of the Red River at Boyce, Louisiana, April 22, 1986.

17. Aerial photograph of the Louisiana Highway 8 crossing of the Red River at Boyce, Louisiana, October 6, 1987

18. Comparative cross sections and pier-scour estimates at Louisiana Highway 6 crossing at Grand Ecore, Louisiana.

19. Aerial photograph of the Louisiana Highway 6 crossing of the Red River at Grand Ecore, Louisiana, September 1, 1977 .

20. Aerial photograph of the Louisiana Highway 6 crossing of the Red River at Grand Ecore, Louisiana, October 7, 1988

21. Comparative cross sections and pier-scour estimates at U.S. Highway 84 crossing at Coushatta, Louisiana.

22. Aerial photograph of the U.S. Highway 84 crossing of the Red River at Coushatta, Louisiana, February 21, 1977.

23. Aerial photograph of the U.S. Highway 84 crossing of the Red River at Coushatta, Louisiana, October 6, 1987 
24. Comparative cross sections and pier-scour estimates at Louisiana Highway 511 crossing at Shreveport, Louisiana

25. Aerial photograph of the Louisiana Highway 511 crossing of the Red River at Shreveport, Louisiana, October 6, 1987.

26. Aerial photograph of the Louisiana Highway 511 crossing of the Red River at Shreveport, Louisiana, March 10, 1989

27. Comparative cross sections and pier-scour estimates at Louisiana Highway 3032 crossing at Shreveport, Louisiana

28. Aerial photograph of the Louisiana Highway 3032 crossing of the Red River at Shreveport, Louisiana, August 9, 1977

29. Aerial photograph of the Louisiana Highway 3032 crossing of the Red River at Shreveport, Louisiana, October 6, 1987.

30. Comparative cross sections and pier-scour estimates at Interstate Highway 20 crossing at Shreveport, Louisiana

31. Aerial photograph of the Interstate Highway 20 crossing of the Red River at Shreveport, Louisiana, August 9, 1977

32. Aerial photograph of the Interstate Highway 20 crossing of the Red River at Shreveport, Louisiana, October 6, 1988

33. Comparative cross sections and pier-scour estimates at U.S. Highway 80 crossing at Shreveport, Louisiana.

34. Aerial photograph of the U.S. Highway 80 crossing of the Red River at Shreveport, Louisiana, August 9, 1977

35. Aerial photograph of the U.S. Highway 80 crossing of the Red River at Shreveport, Louisiana, October 6, 1987

36. Comparative cross sections and pier-scour estimates at Interstate Highway 220 crossing at Shreveport, Louisiana

37. Aerial photograph of the Interstate Highway 220 crossing of the Red River at Shreveport, Louisiana, January 20, 1977

38. Aerial photograph of the Interstate Highway 220 crossing of the Red River at Shreveport, Louisiana, October 6, 1987

39. Comparative cross sections and pier-scour estimates at Louisiana Highway 2 crossing near Hosston, Louisiana

40. Aerial photograph of the Louisiana Highway 2 crossing of the Red River near Hosston, Louisiana, August 9, 1977

41. Aerial photograph of the Louisiana Highway 2 crossing of the Red River near Hosston, Louisiana, October 6, 1987

\section{TABLES}

1. Water-surface elevation, 500-year flood estimate, main-channel width, and flood-plain width at highway crossings of the Red River, Louisiana.

2. Flood estimates for the Red River at Alexandria and Shreveport, Louisiana, and Fulton, Arkansas .........

3. Pier-scour estimates for Louisiana Highway 107 crossing the Red River near Moncla, Louisiana......

4. Pier-scour estimates for U.S. Highways 167, 165, and 71 crossing the Red River at Alexandria, Louisiana

5. Pier-scour estimates for Louisiana Highway 8 crossing the Red River at Boyce, Louisiana

Pier-scour estimates for Louisiana Highway 6 crossing the Red River at Grand Ecore, Louisiana

7. Pier-scour estimates for U.S. Highway 84 crossing the Red River at Coushatta, Louisiana ...................

8. Pier-scour estimates for Louisiana Highways 511 and 3032, Interstate Highway 20, and U.S. Highway 80 crossing the Red River at Shreveport, Louisiana .....

9. Pier-scour estimates for Interstate Highway 220 crossing the Red River near Shreveport, Louisiana....... 56

10. Pier-scour estimates for Louisiana Highway 2 crossing the Red River near Hosston, Louisiana .............. 58 


\section{CONVERSION FACTORS AND VERTICAL DATUM}

\begin{tabular}{rll}
\hline Multiply & \multicolumn{1}{c}{ By } & To obtain \\
\hline foot $(\mathrm{ft})$ & 0.3048 & meter \\
foot per second $(\mathrm{ft} / \mathrm{s})$ & 0.3048 & meter per second \\
foot per foot $(\mathrm{ft} / \mathrm{ft})$ & 0.3048 & meter per meter \\
cubic foot per second $\left(\mathrm{ft}^{3} / \mathrm{s}\right)$ & 0.02832 & cubic meter per second \\
mile $(\mathrm{mi})$ & 1.609 & kilometer \\
square mile $\left(\mathrm{mi}^{2}\right)$ & 2.590 & square kilometer \\
\hline
\end{tabular}

Sea level: In this report "sea level" refers to the National Geodetic Vertical Datum of 1929--a geodetic datum derived from a general adjustment of the first-order level nets of both the United States and Canada, formerly called Sea Level Datum of 1929. 


\title{
Estimation of Pier Scour and Channel Stability for Highway Crossings of the Red River in Louisianc
}

\author{
By J. Josh Gilbert and Paul A. Ensminger
}

\begin{abstract}
Thirteen bridges that cross the Red River in Louisiana were evaluated for pier scour and channel stability. The analyses performed at each bridge were based on guidelines described in Hydrologic Engineering Circular 18 (HEC 18) and Hydrologic Engineering Circular 20 (HEC 20).

Long-term aggradation and degradation of the channel at the bridge sites were evaluated using historic hydrographic information, aerial photographs, and site inspections. Contraction scour was not present because bridge abutments were landward of the flood protection levee system along the river, or were above the 500-year flood estimate. Pier-scour depth estimates ranged from 3.0 feet at Louisiara Highway 3032 to 47 feet at U.S. Highway 167.

The greatest pier-scour estimate was for Interstate Highway 20 near Shreveport where 38 feet was estimated at the pier at Department of Transportation and Development station $320+85$. The greatest channel-bed dynamics was observed at Louisiana Highway 2 near Hosston where thalweg elevations 21 feet deeper than the ambient bed moved laterally across the cross section.
\end{abstract}

\section{INTRODUCTION}

The design, construction, and maintenance of highway crossings over rivers and flood plains require consideration of design variables such as bridge and embankment section lengths, pier spacing, and pile penetration. Bridge design must consider the cost and effort of construction, maintenance, and safety requirements. The Federal Highway Administration requires that all State highway agencies evaluate bridges in the Federal aid system for scour susceptibility. The U.S. Geological Survey (USGS), in cooperation with the Louisiana Department of Transportation and Development (DOTD), began this stuc'y in 1991 to evaluate pier scour and channel stability of selected bridges that cross the Red River. One of tre bridges evaluated, Louisiana Highway (La. Hwy.) 3032 near Shreveport, is part of the USGS National Bridge Scour Program. Part of the mission of the National Bridge Scour Program is to collect scour data at selected sites in the United States.

The magnitude of the 500-year flood estimate used in the scour analyses was estimated as outlined by the Interagency Advisory Committee on Water Data using a log Pearson Type III distribution. Gagir $g$ stations along the Red River were individually evaluated to determine their 500-year flood estimate. Tro 500 -year flood estimates ranged from 249,700 to 386,700 cubic feet per second at the 13 bridge siter. Water-surface elevations associated with the 500-year flood estimates ranged from 71.1 to 198.6 feet above sea level.

In Louisiana, the reach of the Red River evaluated is primarily a sand-bed stream that ranges in width from 500 to 1,350 feet. Most of this reach is confined by flood protection levees on one or both banks, has a flood plain that ranges in width from 800 to 3,000 feet, and ranges in drainage area from 57,035 to 67,527 square miles. Bank and channel stabilization measures were placed along the river to stabilize the channel as well as to protect facilities along the river from erosion. 


\section{Purpose and Scope}

This report describes pier scour and channel stability at 13 bridges that cross the Red River in Louisiana. All hydrologic, hydraulic, and hydrographic information used in this evaluation are derived from previously collected data. The bridge, pier, and pile geometry examined in this report are derived from DOTD bridge plans.

\section{Description of Study Area}

The Red River originates in eastern New Mexico and flows southeasterly across the Texas panhandle. The distance from the Red River's source to the river's junction with the Atchafalaya River is about 1,20 ) river miles. The total drainage area of the Red River basin at the mouth is about 93,000 mi ${ }^{2}$. Red River mileage, established by the U.S. Army Corps of Engineers (COE), is measured in an upstream direction beginning at river mile 0.0 (fig. 1).

This analysis focuses on the reach of the Red River from the north Louisiana State line to the river's confluence with the Atchafalaya River at river mile 0.0. Thirteen bridges across the Red River near Moncla, Alexandria, Boyce, Grand Ecore, Coushatta, Shreveport, and Hosston, La. (figs. 1 and 2), were evaluate-1 for scour potential and channel stability. This reach of the river is bounded on one or both banks by levees. 800 to $3,000 \mathrm{ft}$ apart, has a main channel that ranges from 500 to $1,350 \mathrm{ft}$ in width at the 13 highway crossings listed in table 1 , and has a general flood slope of $0.0001 \mathrm{ft} / \mathrm{ft}$. In this reach, the river cuts through an alluvial deposit that is primarily composed of sand, silt, and clay.

Biedenharn and others (1989) reported that the radius-width ratio of the Red River ranges from 1.5 to 2.0. Nanson and Hickin (1986) stated that the maximum rate of channel migration occurs in rivers with a radius-width ratio of 2 to 3 . Although the radius-width ratios on the Red River approaches the lower limit defined by Nanson and Hackin for maximum channel migration, bank stabilization measures placed along the river by the COE and others tend to arrest large scale channel migration. Also, Biedenharn and others (1989) reported that the average channel slope is $0.00013 \mathrm{ft} / \mathrm{ft}$, the median particle size of the bed material is approximately $0.0008 \mathrm{ft}(0.25 \mathrm{~mm})$, and the bank material is typically a finer grain with a particle size of approximately $0.0003 \mathrm{ft}(0.10 \mathrm{~mm})$. Limited bed samples collected from the Red River in 1983 by the USGS support this range of 0.0003 to $0.0008 \mathrm{ft}$ as the grain size for the bed material and banks.

\section{ACKNOWLEDGMENTS}

The assistance of Mr. Jack Manno and Mr. Fred Cifreo of the Louisiana Department of Transportation and Development, and Mr. Fred Pinkard of the U.S. Army Corps of Engineers, Vicksburg District, in providing hydrographic survey information on the Red River is gratefully acknowledged. 


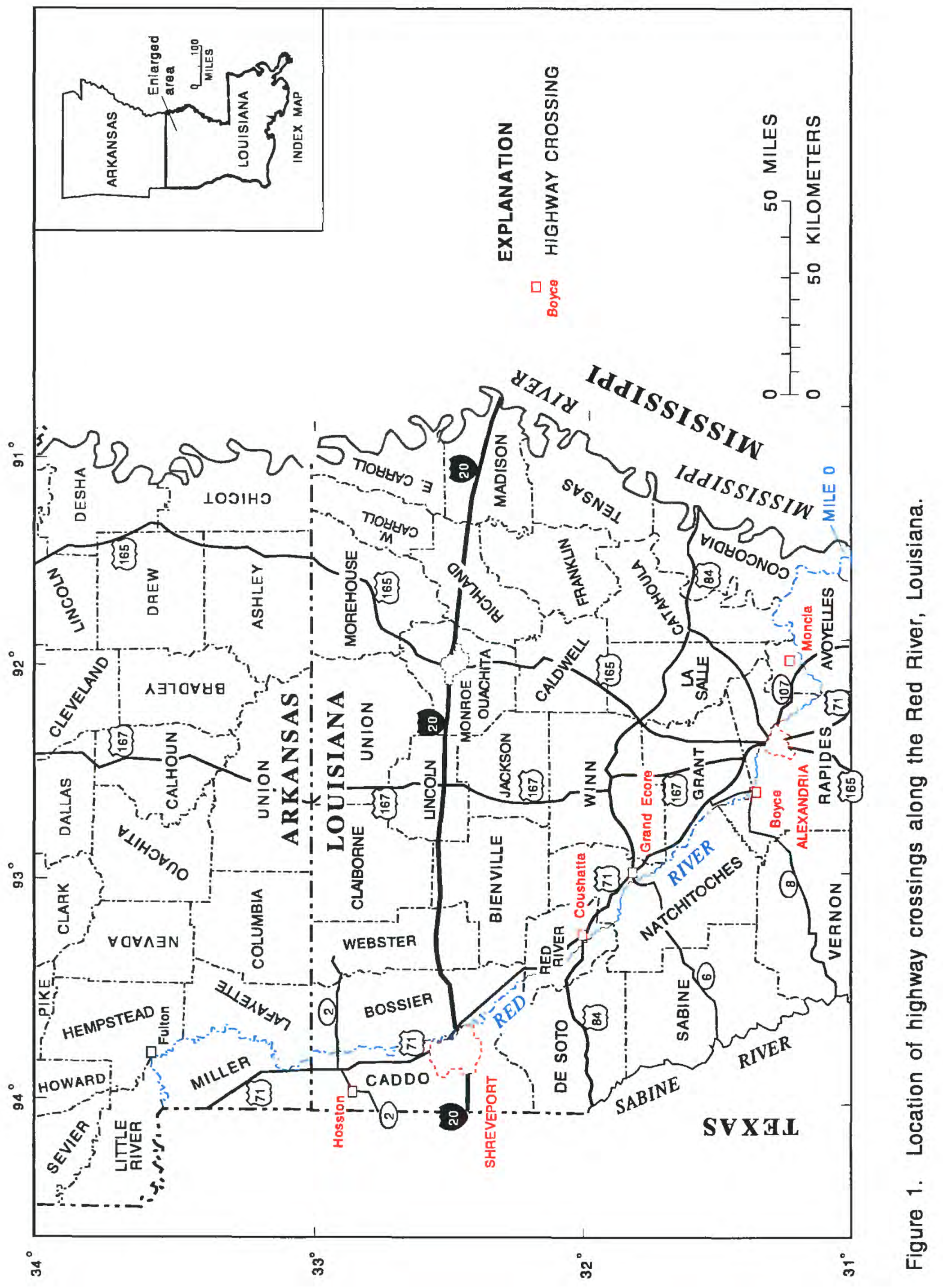



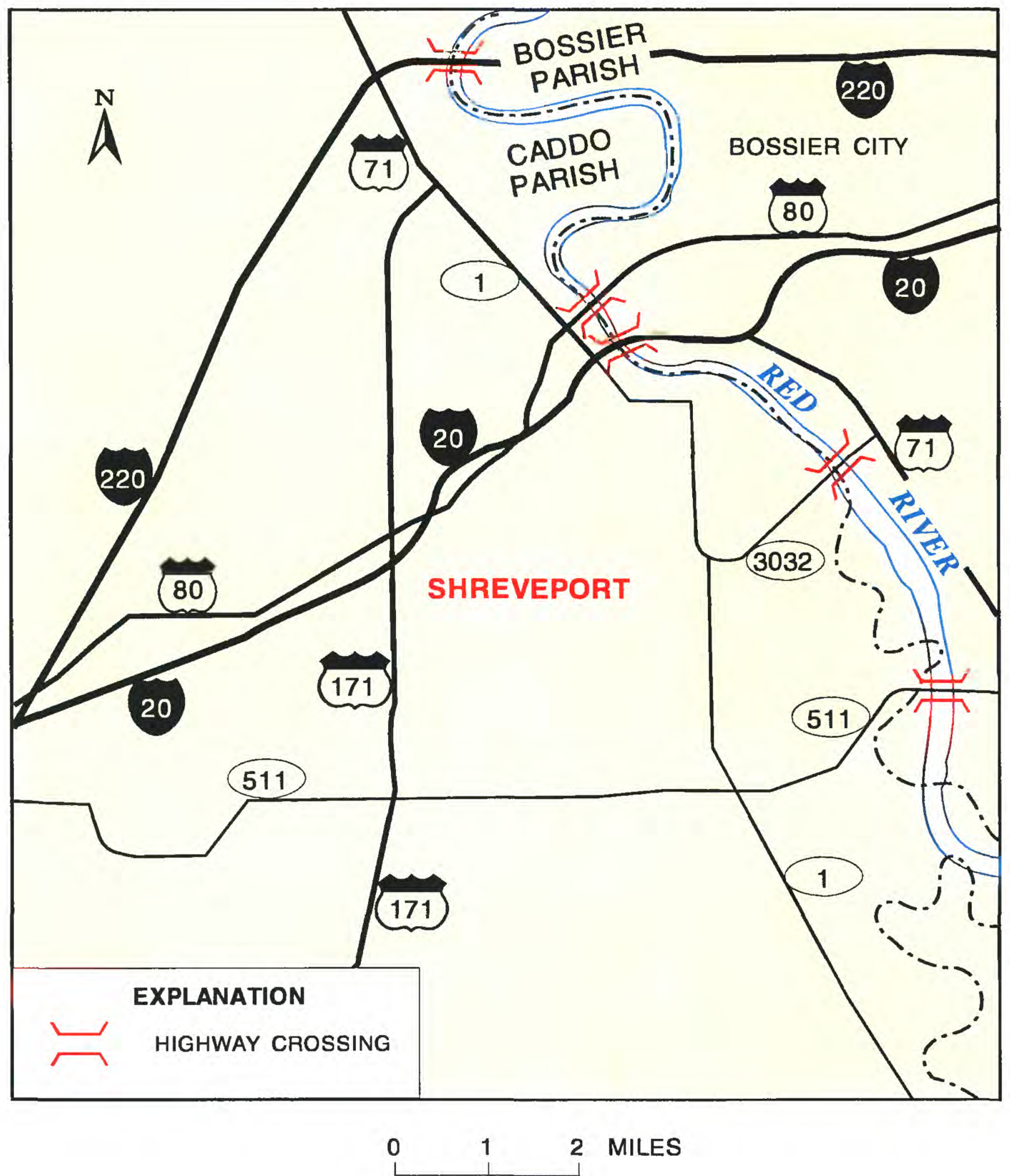

Figure 2. Location of highway crossings evaluated in the vicinity of Shreveport, Louisiana. 
Table 1. Water-surface elevation, 500-year flood estimate, main-channel width, and flood-plain width at highway crossings of the Red River, Louisiana

\begin{tabular}{|c|c|c|c|c|c|c|}
\hline Site identification & $\begin{array}{l}\text { River } \\
\text { mile }\end{array}$ & $\begin{array}{c}\text { Drainage } \\
\text { area, } \\
\text { in square miles }\end{array}$ & $\begin{array}{l}\text { Water-surface } \\
\text { elevation } 1 \text {, in } \\
\text { feet above } \\
\text { sea level }\end{array}$ & $\begin{array}{l}\text { 500-year flood } \\
\text { estimate, } \\
\text { in cubic feet } \\
\text { per second }\end{array}$ & $\begin{array}{l}\text { Main-channel } \\
\text { width, } \\
\text { in feet }\end{array}$ & $\begin{array}{l}\text { Flood-plain } \\
\text { width, } \\
\text { in feet }\end{array}$ \\
\hline Louisiana Highway 107 near Moncla & 67 & 67,527 & 71.1 & 249,700 & 950 & 1,100 \\
\hline U.S. Highway 167 at Alexandria & 105 & 67,412 & 89.0 & 251,700 & 500 & 800 \\
\hline U.S. Highway 165 at Alexandria & 105 & 67,412 & 90.0 & 251,700 & 600 & 800 \\
\hline U.S. Highway 71 at Alexandria & 106 & 67,412 & 91.0 & 251,700 & 750 & 1,300 \\
\hline Louisiana Highway 8 at Boyce & 126 & 66,909 & 97.0 & 260,500 & 650 & 1,500 \\
\hline Louisiana Highway 6 at Grand Ecore & 184 & 64,524 & 120.0 & 302,500 & 600 & 1,100 \\
\hline U.S. Highway 84 at Coushatta & 221 & 63,309 & 138.0 & 323,900 & 550 & 2,000 \\
\hline Louisiana Highway 511 at Shreveport & 272 & 60,614 & 171.4 & 371,300 & 1,300 & 2,500 \\
\hline Louisiana Highway 3032 at Shreveport & 274 & 60,614 & 172.3 & 371,300 & 700 & 2,400 \\
\hline Interstate Highway 20 at Shreveport & 277 & 60,614 & 177.0 & 371,300 & 600 & 1,300 \\
\hline U.S. Highway 80 at Shreveport & 278 & 60,614 & 178.0 & 371,300 & 600 & 1,300 \\
\hline Interstate Highway 220 at Shreveport & 283 & 60,614 & 178.7 & 371,300 & 1,200 & 3,000 \\
\hline Louisiana Highway 2 near Hosston & 318 & 57,035 & 198.6 & 386,700 & 1,350 & 2,710 \\
\hline
\end{tabular}

${ }^{1}$ Calculated using the 500-year flood estimate.

\section{HYDROLOGY AND HYDRAULICS}

A flood-frequency analysis was performed to determine the 500-year flood estimate for streamflow' gaging stations along the Red River at Alexandria, La., at Shreveport, La., and at Fulton, Ark. (table 2). The period analyzed was from 1943 to 1990, after Texoma Dam, Arkansas, was completed and represents the regulated condition. These flood estimates were determined by fitting the three-parameter Pearson type III distribution to the sample of log-transformed annual-peak discharges as recommended by the Interagenc: Advisory Committee on Water Data (IACWD, 1982). A linear representation was used to provide flood estimates at ungaged sites within the study area.

Table 2. Flood estimates for the Red River at Alexandria and Shreveport, Louisiana, and Fulton, Arkansas

\begin{tabular}{lcc}
\hline Site & $\begin{array}{c}\text { 100-year flood estimate, } \\
\text { in cubic feet per second }\end{array}$ & $\begin{array}{c}\text { 500-year flood estimate, } \\
\text { in cubic feet per second }\end{array}$ \\
\hline Alexandria & 238,500 & 251,700 \\
Shreveport & 295,300 & 371,300 \\
Fulton & 307,600 & 432,500 \\
\hline
\end{tabular}

The 500-year flood estimates for selected sites along the Red River are shown in figure 3. The "overtopping flood," as defined by Richardson and others (1993, p. 22), was not evaluated, because bridge. decks are elevated above the flood protection levees and far exceed the elevation of the surrounding terrain and the 500-year flood estimates. 


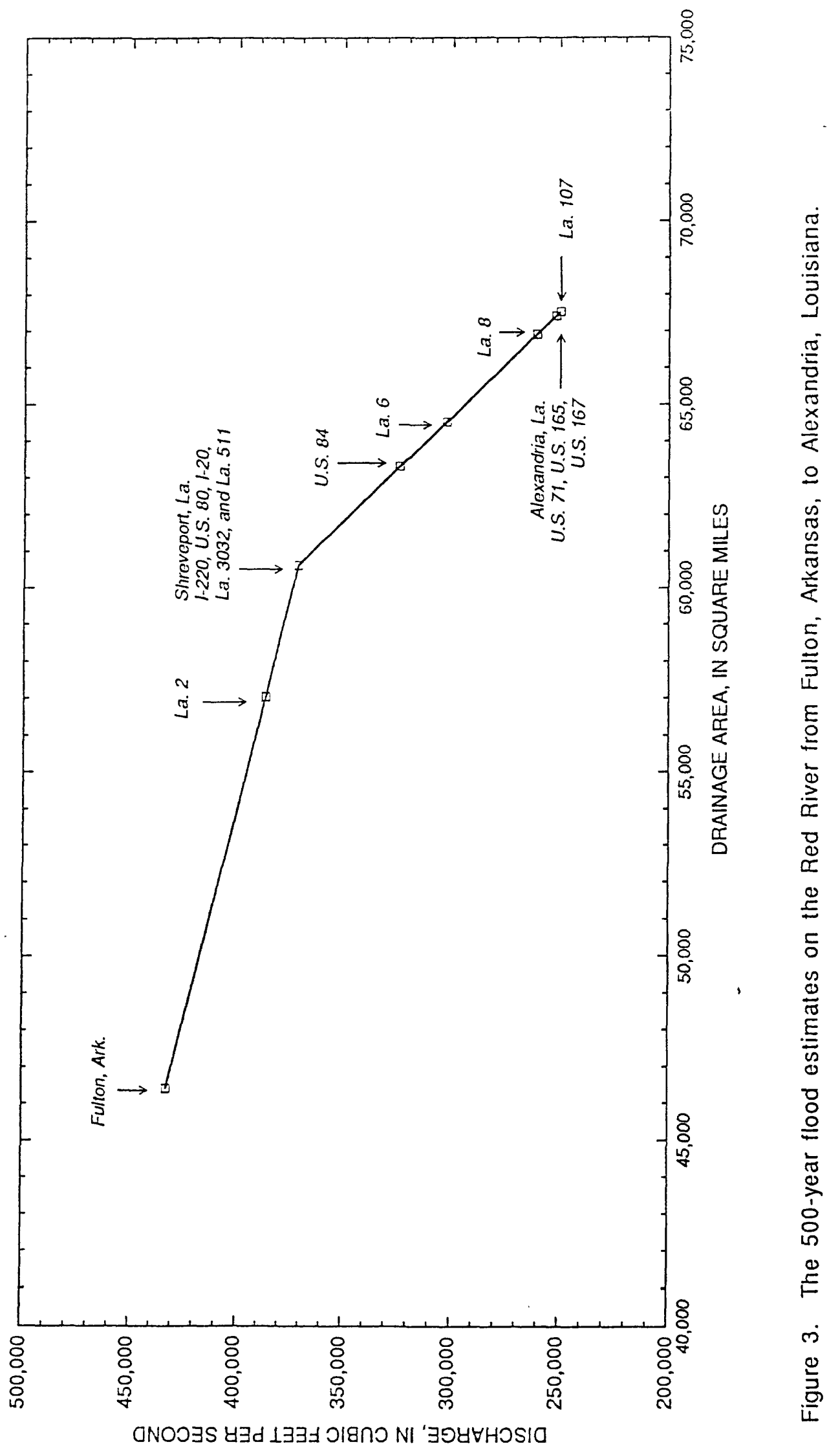


A computer program, water-surface profiles (WSPRO) (Shearman and others, 1986), was used to calculate the water-surface elevations for annual-peak discharges of record and for the 500 -year floot estimate. In the initial WSPRO analyses, a flood slope between 0.0001 and $0.0004 \mathrm{ft} / \mathrm{ft}$, in conjunction with cross-sectional properties, was used to calculate a starting downstream water-surface elevation. Roughness coefficients ranged from 0.025 to 0.035 in the main channel, and 0.06 to 0.08 on the overbanks. The resulting calculated water-surface elevations at the highway crossings were compared to the observet water-surface elevations. Model adjustments were made when necessary to provide adequate calibration $c^{f}$ the WSPRO model results.

\section{SCOUR ANALYSIS}

\section{Channel Stability}

Historical hydrographic data were examined to evaluate any trends indicating long-term aggradation, degradation, or shifting of the channel at the 13 bridge sites. Channel geometry changes at some sites indicated long-term trends, whereas other sites indicated only the seasonal, relatively low-magnitude, dynamic behavior of the Red River.

The interaction of factors that affect long-term aggradation, degradation, or shifting of the channel are complex and difficult to predict. Migration of river meanders is influenced by factors such as boundary material composition, bank height and angle, and variations in hydrologic and hydraulic conditions. In addition, channel planform and extent of vegetation in the overbank area can influence channel migration. The site-specific mechanisms responsible for bank erosion vary along the Red River. Thorne (1989) notef that bank retreat usually is caused by a combination of flow erosion of intact bank material and mass failure of the bank due to gravity, followed by removal of the material from the bank toe. Regardless of the mechanism, bed-form changes are ultimately a function of the hydraulic process, which is largel :' determined by the planform and flow geometry. In this report, an evaluation of potential aggradation, degradation, or shifting of the bed was based on the historic observed channel changes. The greatest amount of historical hydrographic information was at the U.S. Hwy. 80 at the Shreveport, La., crossing where five independent cross sections measured in 1931, 1932, 1969, 1980, and 1992 were evaluated.

The examination of channel-bed elevations at an individual site over time can indicate fairl:' substantial bed changes between individual surveys, but changes noted between two surveys may not appear substantial when compared to many surveys. The most notable example of this would be a comparison of two hydrographic surveys, one performed during low-flow conditions, and the other during high-flow conditions. For sites addressed in this report, the channel conditions from the COE calibration data set were initially used for analysis. The site was then evaluated using the most recent observed bridge section.

\section{Contraction and Abutment Scour}

In general, 13 bridges are elevated on piles above the top of the levee, with no embankment fill material riverward of the levee. Given this type of structure and flow conditions, there is no contraction due to encroachments; therefore, no contraction or abutment scour is present. The fixed-bed hydraulics were not modified to reflect contraction-scoured conditions, but were represented by the most applicable hydrographic survey. Accumulation of debris on the bridge and pier structure is expected to be minimal at the 13 bridge sites, based on the performance of similar structures in this flow environment. 


\section{Pier Scour Equation}

Local scour at the pier locations is calculated using the Colorado State University equation (modified from Richardson and others, 1993, eq. 2).

$$
\begin{gathered}
\mathrm{y}_{\mathrm{s}} / \mathrm{y}_{1}=2.0 \times \mathrm{K}_{1} \times \mathrm{K}_{2} \times \mathrm{K}_{3} \times\left(\mathrm{a} / \mathrm{y}_{1}\right)^{0.65} \times(\mathrm{Fr})^{0.43}, \\
\mathrm{y}_{\mathrm{d}}=\mathrm{GSE}-\mathrm{y}_{\mathrm{s}},
\end{gathered}
$$

where $\quad y_{s}=$ estimated depth of pier scour, in feet;

$\mathrm{y}_{1}=$ flow depth directly upstream of the pier, in feet;

$\mathrm{K}_{1}=$ dimensionless correction factor for pier nose shape;

$\mathrm{K}_{2}=$ dimensionless correction factor for skew;

$\mathrm{K}_{3}=$ dimensionless correction factor for bed form;

$\mathrm{a}=$ width of pier, in feet;

$\mathrm{Fr}=$ Froude number;

$y_{d}=$ channel-bed elevation of the computed scour hole, in feet above sea level; and

GSE = observed ambient ground-surface (channel-bed) elevation, in feet above sea level.

The value for $y_{1}$ at each pier was based upon the difference between the computed water-surface elevation and the most appropriate ground-surface elevation. The minimum channel-bed elevaticn historically observed at that location, or the potential channel-bed elevation may be chosen as the mot appropriate ground-surface information. The values for $\mathrm{K}_{1}, \mathrm{~K}_{2}$, and $\mathrm{K}_{3}$ were taken from values recommended by Richardson and others (1993, p. 39-40) for pier geometry as represented on DOTD bridge plans. The Froude number at the pier location is based upon the value of velocity, which was computed using WSPRO.

\section{HIGHWAY CROSSINGS OF THE RED RIVER IN LOUISIANA}

\section{Louisiana Highway 107 near Moncla, Louisiana}

The COE maintains a gage at the La. Hwy. 107 bridge crossing the Red River near Moncla and has recorded the stage of the Red River from 1935 to 1985 . The peak stage of record was $70.9 \mathrm{ft}$ above sea level and occurred in 1935. For the 51 years of stage record, five peak stages exceeded $68 \mathrm{ft}$ above sea level. Although the peak-stage data cover 50 years, there are only 5 years of flood-discharge record (1938-42). The maximum discharge measured during the 5 years was $168,000 \mathrm{ft}^{3} / \mathrm{s}$ in 1942 , with a flood stage of 68.5 $\mathrm{ft}$ above sea level. The limited flood-discharge data near Moncla are not sufficient to determine flood-frequency estimates.

The starting downstream water-surface elevation must be specified at $70.0 \mathrm{ft}$ above sea level for computed water-surface elevations from WSPRO to match the recorded historical stage elevations. This is an increase of $10.0 \mathrm{ft}$ more than the slope conveyance starting water-surface elevation of approximately $60.0 \mathrm{ft}$ above sea level. The increased stage recorded in gage records is most likely due to backwater from Black River. 


\section{Pier Scour}

The results of the hydraulic simulations indicate that a discharge of $249,700 \mathrm{ft}^{3} / \mathrm{s}$ (table 1 ) produces a water-surface elevation of $71.1 \mathrm{ft}$ above sea level (table 3), an energy gradeline with a slope of approximately 0.00002 , and Froude numbers ranging from 0.10 to 0.35 along the cross section. Tlo main-span pier geometry is a sharp-nosed pier, $12 \mathrm{ft}$ wide and $44 \mathrm{ft}$ long. Values of $\mathrm{y}_{1}$ were based on $\mathrm{tl}^{\text {' }}$ ? COE survey of 1968 . Values of $\mathrm{K}_{1}, \mathrm{~K}_{2}$, and $\mathrm{K}_{3}$ are 1.0, 1.0, and 1.1, respectively, recommended ty Richardson and others (1993, p. 39-40), and Lagasse and others (1991). The width of the scour holes was based on the recommendations by Richardson and others (1991, p. 28) of a bed width of $5 \mathrm{ft}$ greater than the pier width, and a top width of $2.75 \times y_{s}$. For the spacing between the piers, no scour holes overlapped.

The predicted depth and width of the scour holes for all bridge supports between the levees are show'n in figure 4 and listed in table 3. Piers at DOTD station $138+25$ through $143+65$ on the right overbank had scour depths from 9 to $10 \mathrm{ft}$. The elevations of the estimated depth of pier-scour holes ranged from 45 to $53 \mathrm{ft}$ above sea level. Scour estimation for the pier at DOTD station 143+65 should also consider long-term channel changes mentioned in the Channel Stability section. The scour depth at the main piers, DOTD stations $147+05$ and $151+30$, is approximately 21 and $19 \mathrm{ft}$. The channel-bed elevation of the predicted scour holes is about $4 \mathrm{ft}$ above sea level at DOTD station 147+05 and $21 \mathrm{ft}$ above sea level at DOTD station $151+30$. Estimates for the pier at DOTD station 154+70, located at the riverward edge of the left overbank, show $12 \mathrm{ft}$ of scour with a pier-scour channel-bed elevation of about $43 \mathrm{ft}$ above sea level. At DOTD stations $155+95,157+20$, and $158+45$ the estimated scour depths from 9 to $10 \mathrm{ft}$ (table 3 ).

Table 3. Pier-scour estimates for Louisiana Highway 107 crossing the Red River near Moncla, Louisiana

[DOTD, Louisiana Department of Transportation and Development; WSE, water-surface elevation, in feet above sea level; GS:, ground-surface (channel-bed) elevation, in feet above sea level; a, width of pier, in feet; $K_{1}$, dimensionless correction factor for pier nose shape; $K_{2}$, dimensionless correction factor for angle of flow attack; $K_{3}$, dimensionless correction factor for channel-bed condition; Fr, Froude number computed at the location; $y_{S}$, estimated depth of pier scour, in feet; $y_{1}$, flow depth directly upstream of the pier, in feet; Tw, estimated top width of the scour hole, in feet; $\mathrm{V}$, velocity computed for that location in the cross section, in feet per second; $y_{d}$, channel-bed elevation of the computed scour hole, in feet above sea level]

\begin{tabular}{|c|c|c|c|c|c|c|c|c|c|c|c|c|}
\hline $\begin{array}{l}\text { DOTD } \\
\text { station }\end{array}$ & WSE & GSE & $\mathbf{a}$ & $\mathbf{K}_{1}$ & $\mathbf{K}_{2}$ & $\mathbf{K}_{3}$ & $\mathbf{F r}$ & $y_{S}$ & $y_{1}$ & Tw & $\mathbf{v}$ & $\mathbf{y}_{\mathrm{d}}$ \\
\hline \multicolumn{13}{|c|}{$\underline{\text { Right overbank piers }}$} \\
\hline $138+25$ & 71.1 & 60 & 10 & 1.0 & 1.0 & 1.1 & 0.12 & 9 & 11.1 & 25 & 2.3 & 51 \\
\hline $139+60$ & 71.1 & 55 & 10 & 1.0 & 1.0 & 1.1 & .10 & 10 & 16.1 & 27 & 2.3 & 45 \\
\hline $140+95$ & 71.1 & 62 & 10 & 1.0 & 1.0 & 1.1 & .13 & 9 & 9.1 & 25 & 2.3 & 53 \\
\hline $142+30$ & 71.1 & 58 & 10 & 1.0 & 1.0 & 1.1 & .11 & 9 & 13.1 & 24 & 2.3 & 49 \\
\hline $143+65$ & 71.1 & 62 & 10 & 1.0 & 1.0 & 1.1 & .13 & 9 & 9.1 & 25 & 2.3 & 53 \\
\hline \multicolumn{13}{|c|}{$\underline{\text { Right main pier }}$} \\
\hline $147+05$ & 71.1 & 25 & 12 & 1.0 & 1.0 & 1.1 & .19 & 21 & 46.1 & 58 & 7.5 & 4 \\
\hline \multicolumn{13}{|c|}{ Left main pier } \\
\hline $151+30$ & 71.1 & 40 & 12 & 1.0 & 1.0 & 1.1 & .22 & 19 & 31.1 & 53 & 6.9 & 21 \\
\hline \multicolumn{13}{|c|}{ Left overbank piers } \\
\hline $154+70$ & 71.1 & 55 & 10 & 1.0 & 1.0 & 1.1 & .15 & 12 & 16.1 & 32 & 3.5 & 43 \\
\hline $155+95$ & 71.1 & 68 & 10 & 1.0 & 1.0 & 1.1 & .35 & 9 & 3.1 & 26 & 3.5 & 59 \\
\hline $157+20$ & 71.1 & 68 & 10 & 1.0 & 1.0 & 1.1 & .35 & 9 & 3.1 & 26 & 3.5 & 59 \\
\hline $158+45$ & 71.1 & 65 & 10 & 1.0 & 1.0 & 1.1 & .25 & 10 & 6.1 & 28 & 3.5 & 55 \\
\hline
\end{tabular}

${ }^{1}$ Numbers are rounded to the nearest foot. 


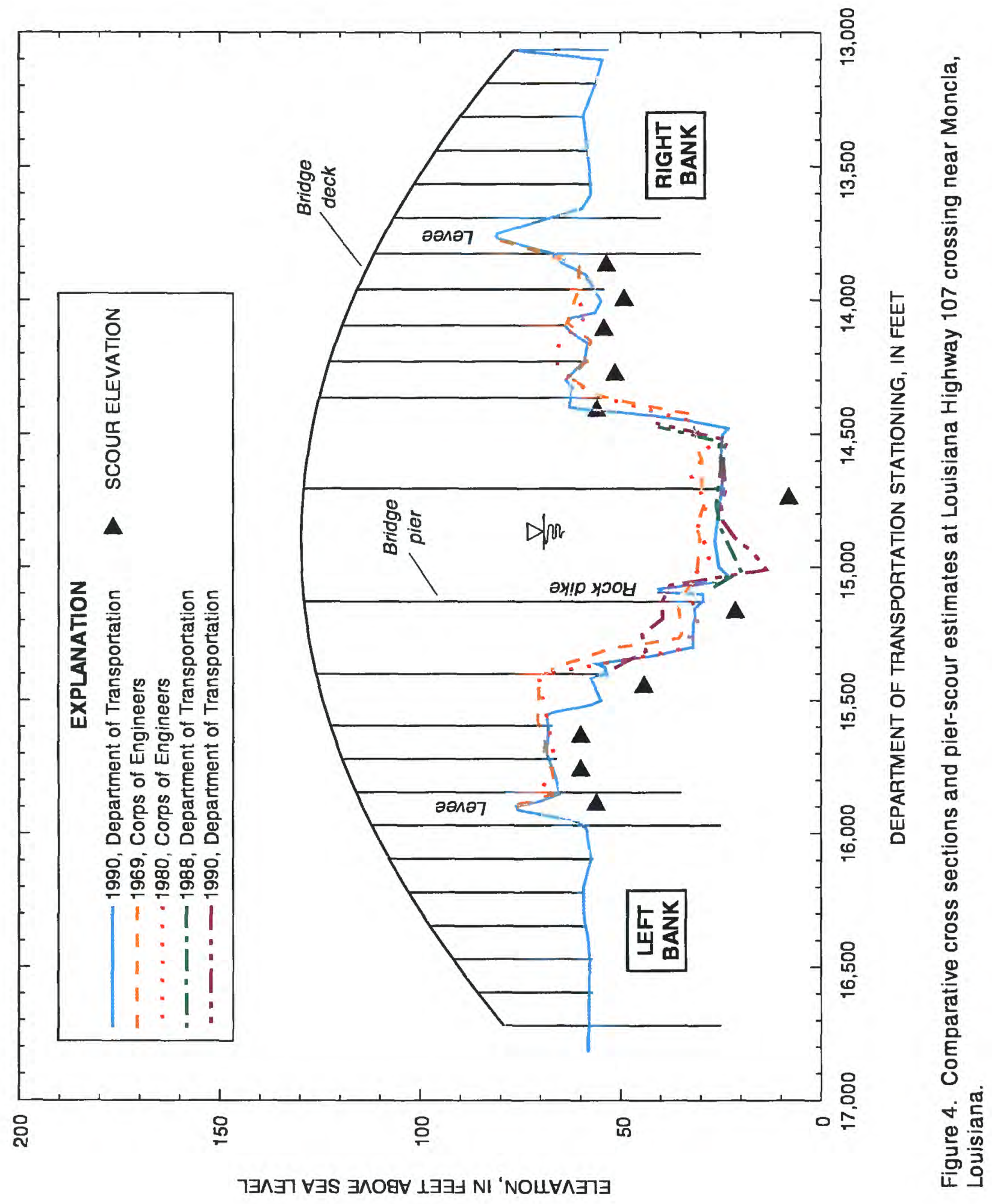




\section{Channel Stability}

A comparison of the historic hydrographic information in the vicinity of Moncla using the $\mathrm{COE}$ hydrographic survey of 1969 and 1990 indicates the river bed degraded about $5 \mathrm{ft}$ during the 20-year perior. Additional cross-sectional information was taken from limited hydrographic surveys performed by DOTD. A comparison of the DOTD surveys of 1988 and 1990 (fig. 4) indicates channel-bed elevations in 1990 were approximately $5 \mathrm{ft}$ lower at one location, but were unchanged at other locations. The observed channel-bed fluctuations could result from a combination of the normal dynamic behavior of the river channel over a wide range of streamflows, and the local effect of the rock dike on the channel cross section (fig. 4). Although local scouring, filling, and transient bed forms alter channel depth periodically, the long-term minimum channel-bed elevation may be relatively stable at $25 \mathrm{ft}$ above sea level, and neither aggrading nor degrading substantially.

An important significant factor affecting channel geometry is the COE system of alternatirg revetments that armor the bed and banks of the Red River where the flow impinges on the bank. A revetment is a series of concrete slabs wired together into a mattress, resembling a giant venetian blind, to protect against erosion from the top bank to the thalweg. These longitudinally placed revetments effectively reinforce the desired bank. A revetment of this type, in addition to a rock dike, is on the left bank near Moncla.

The aerial photographs taken by DOTD, October 5, 1987 (fig. 5), and November 1, 1988 (fig. 6), show the location of the rock dike along the left bank. Under normal flow conditions, this rock dike near Moncla may facilitate deposition of the coarser suspended sediments in the area landward of the dike. The aerial photographs indicate some deposition behind the rock dike.

Continued maintenance of the current rock dike and revetment may prevent the meander from shifting and eroding the left bank. Eventually, stabilizing vegetation may grow between the dike and bank to further protect the left bank. If a flood breaches the rock dike and revetment prior to growth of soil-stabilizing vegetation, the newly deposited material will erode substantially. The left bank landward of the tree line appears stable from aerial photographs; this stability indicates that the bank around the pier at DOTD station $155+95$ may not be readily susceptible to erosion.

Lateral stability assessment was based on data from limited hydrographic records, aerial photograpt? (figs. 5 and 6), and field inspection. The DOTD cross sections at La. Hwy. 107 (fig. 4) indicate the dynamics of the channel bed, but the shape and position of main channel is generally unchanging. The 1988 and 1990 DOTD surveys show a reduction in channel-bed elevation of approximately $5 \mathrm{ft}$ at the low point in the cross sections (fig. 4). Although the DOTD surveys are limited in extent on the right bank, and provice information on only the riverward edge of the right bank, other indications of right-bank instability were evident from visual inspection in 1990. Large trees, old fence lines, and part of the right bank had fatlen into the river. Crescent-shaped sections of the right bank showed recent slumping and mass wasting. Tre extent of right-bank degradation is uncertain; however, the rock dike has reduced the medium- to low-water width of the river. Before the placement of the rock dike, the width of the Red River main channel for medium flows near Moncla was about $900 \mathrm{ft}$ (figs. 5 and 6), compared to the width of $700 \mathrm{ft}$ after the dike construction. The rock dike is about $300 \mathrm{ft}$ from the mature tree line on the left bank. Extending the median 900 -foot width channel from the rock dike is a rough indicator of the potentially erodible area of the rigl ${ }^{+}$ bank. If this bank material eroded, piers at DOTD stations $142+30$ and $143+65$ could be susceptible to scour. Given the potential for erosion on the right bank an estimate of approximately $20 \mathrm{ft}$ of scour, at DOTD station $143+65$, referenced from the existing ground surface, could be considered based on estimates for the main channel piers. 


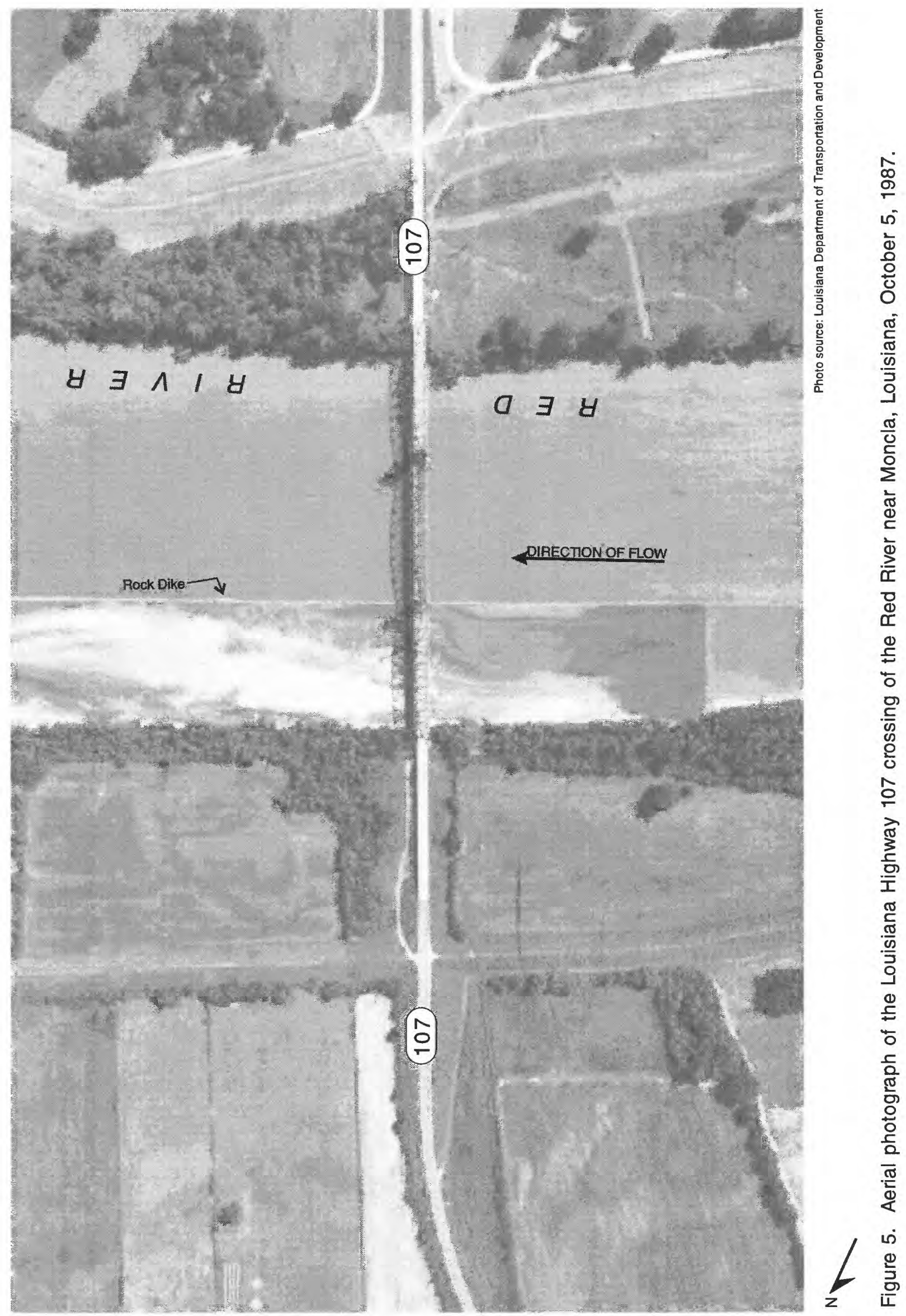




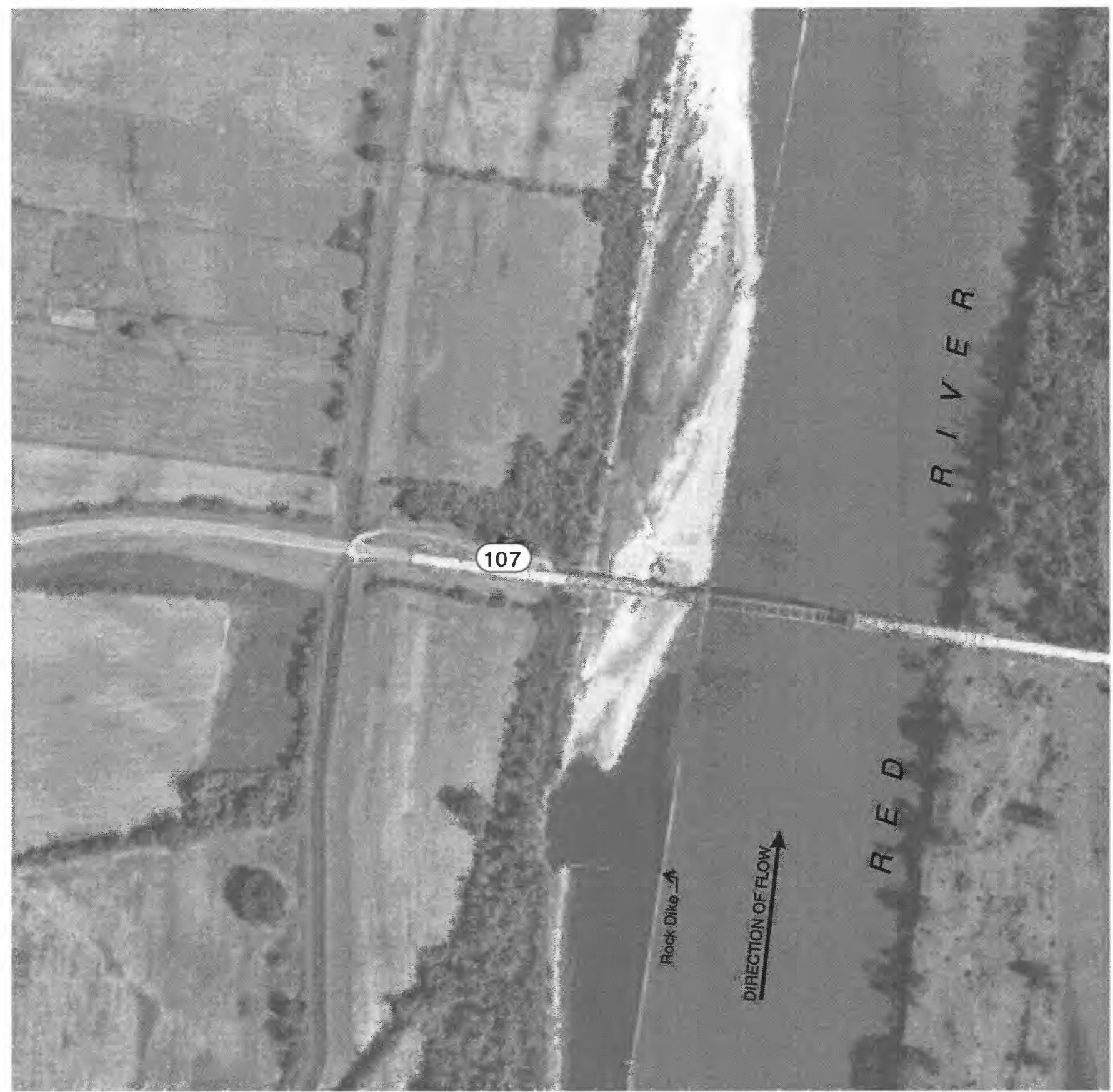

$\mathrm{N}$

Photo source: Louisiana Department of Transportation and Development

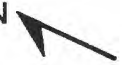

Figure 6. Aerial photograph of the Louisiana Highway 107 crossing of the Red River near Moncla, Louisiana, November 1, 1988. 


\section{U.S. Highways 167, 165, and 71 at Alexandria, Louisiana}

Flood-frequency estimates based on gaging station records for the Red River at Alexandria indicate a 500 -year flood estimate of $251,700 \mathrm{ft}^{3} / \mathrm{s}$ (fig. 3, table 1). The computed water-surface elevation associated with this discharge is approximately 89.5 and $89.0 \mathrm{ft}$ above sea level for the reach representing U.S. Hw'y. 167 and the proposed U.S. Hwy. 167, respectively (table 4). The computed water-surface elevations for U.S. Hwy. 165 and 71 are 90.0 and $91.0 \mathrm{ft}$ above sea level. Three floods that have been recorded at Alexandria since 1945 had discharges that ranged from 200,000 to $233,000 \mathrm{ft}^{3} / \mathrm{s}$. The discharge of 233,000 $\mathrm{ft}^{3} / \mathrm{s}$ has a flood having a recurrence interval of slightly less than 100 years, and corresponds with a water-surface elevation of $89.5 \mathrm{ft}$ above sea level recorded at U.S. Hwy. 165.

The model reach for evaluation of the bridges extends from downstream of U.S. Hwy. 167 to upstream of U.S. Hwy. 71. The width of the channel ranges from approximately 500 to $750 \mathrm{ft}$ throughout the reach. The minimum channel-bed elevations for the cross sections ranged from 13 to $26 \mathrm{ft}$ above s?a level. The downstream starting elevation for computations using WSPRO was $89 \mathrm{ft}$ above sea level. This starting elevation is slightly higher than the starting elevation using a downstream boundary specification of a slope of 0.0001 , but yields computed water-surface elevations that more closely fit the peaks of record. The WSPRO simulations indicate an energy gradeline slope of approximately 0.0001 , and velocitios ranging from 1.2 to $9.6 \mathrm{ft} / \mathrm{s}$ along the cross sections at the bridges (table 4 ).

\section{U.S. Highway 167 at Alexandria, Louisiana}

\section{Pier Scour}

To evaluate pier scour at U.S. Hwy. 167, values for $y_{1}$ at each pier were based on the DOTD hydrographic survey of 1992 . The cross section used for analysis of U.S. Hwy. 167 represents minimum channel-bed elevations of the sections shown in figure 7. The computed scour depths ranged from 9.2 to $47.0 \mathrm{ft}, 74$ to $-17 \mathrm{ft}$ above sea level at the base of the pier-scour hole (table 4). Channel-bed elevations decreased about $10 \mathrm{ft}$ locally between the 1980 and 1992 surveys. This decrease is substantial, compared to the small change during three previous surveys over a 34-year period (1958-92).

The right overbank pier at DOTD station $75+09$, had an estimated scour depth of $11.9 \mathrm{ft}$, which corresponds to a channel-bed elevation of $68 \mathrm{ft}$ above sea level (fig. 7, table 4). The greatest scour depth estimated was $47.0 \mathrm{ft}$ at the right main pier (DOTD station $78+83$ ), and the corresponding channel-bed elevation was $17 \mathrm{ft}$ below sea level. Scour estimated at the left main pier at DOTD station $82+17$ is $40.7 \mathrm{ft}$, and the channel-bed elevation is $1 \mathrm{ft}$ below sea level. The estimated scour depth for these two main chanrel piers is approximately $10 \mathrm{ft}$ from the elevation of the bottom of the piers shown on DOTD bridge plans.

\section{Channel Stability}

Hydrographic surveys of 1958, 1969, and 1980 (fig. 7) do not indicate any substantial trends or changes in the channel at the U.S. Hwy. 167 bridge. The survey performed by the DOTD in 1992 indicates a deepening of the thalweg. It is not known whether the channel change represents a new channel condition, or is transient and short term. The channel-bed elevations from the 1980 and prior surveys range from 28 to $32 \mathrm{ft}$ above sea level. The minimum channel-bed elevation from the 1992 survey is approximately $13 \mathrm{ft}$ above sea level. 
Table 4. Pier-scour estimates for U.S. Highways 167, 165, and 71 crossing the Red River at Alexandria, Louisiana

[DOTD, Louisiana Department of Transportation and Development; WSE, water-surface elevation, in feet above sea level; GSE, ground-surface (channel-bed) elevation, in feet above sea level; a, width of pier, in feet; $\mathrm{K}_{1}$, dimensionless correction factor for pier nose shape; $K_{2}$, dimensionless correction factor for angle of flow attack; $K_{3}$, dimensionless correction factor for channel-bed condition; Fr, Froude number computed at the location; $\mathrm{y}_{\mathrm{S}}$, estimated depth of pier scour, in feet; $\mathrm{y}_{1}$, approach flow depth directly upstream of the pier, in feet; Tw, estimated top width of the scour hole, in feet; $\mathrm{V}$, approach velocity computed for that location in the cross section, in feet per second; $y_{d}$, channel-bed elevation of the computed scour hole, in feet above sea level]

\begin{tabular}{|c|c|c|c|c|c|c|c|c|c|c|c|c|}
\hline $\begin{array}{l}\text { DOTD } \\
\text { station }\end{array}$ & WSE & GSE & a & $\mathbf{K}_{1}$ & $\mathbf{K}_{2}$ & $\mathbf{K}_{3}$ & Fr & $\mathbf{y}_{\mathrm{S}}$ & $\mathbf{y}_{1}$ & Tw & $\mathbf{v}$ & $y_{d}{ }^{\prime}$ \\
\hline \multicolumn{13}{|c|}{ U.S. Highway 167. bridge at Fulton Street } \\
\hline $75+09$ & 89.5 & 80 & 12 & 1.0 & 1.0 & 1.1 & 0.20 & 11.9 & 9.0 & 33 & 3.4 & 68 \\
\hline $78+83$ & 89.5 & 30 & 40 & 1.0 & 1.0 & 1.1 & .17 & 47.0 & 59.0 & 129 & 7.4 & -17 \\
\hline $82+17$ & 89.5 & 40 & 40 & 1.0 & 1.0 & 1.1 & .14 & 40.7 & 49.0 & 112 & 5.6 & -1 \\
\hline $85+91$ & 89.5 & 83 & 12 & 1.0 & 1.0 & 1.1 & .15 & 9.2 & 6.0 & 25 & 2.1 & 74 \\
\hline \multicolumn{13}{|c|}{ U.S. Highway 167, proposed bridge } \\
\hline $103+09$ & 89.0 & 81 & 8 & 1.0 & 1.0 & 1.1 & .21 & 9.0 & 8.0 & 25 & 3.4 & 72 \\
\hline $104+86$ & 89.0 & 60 & 10 & 1.0 & 1.0 & 1.1 & .11 & 12.4 & 29.0 & 34 & 3.4 & 48 \\
\hline $107+31$ & 89.0 & 24 & 12 & 1.0 & 1.0 & 1.1 & .16 & 21.7 & 64.0 & 60 & 7.4 & 3 \\
\hline $110+61$ & 89.0 & 50 & 12 & 1.0 & 1.0 & 1.1 & .16 & 18.0 & 39.0 & 50 & 5.6 & 32 \\
\hline $113+06$ & 89.0 & 85 & 8 & 1.0 & 1.0 & 1.1 & .19 & 6.7 & 4.0 & 18 & 2.1 & 78 \\
\hline $113+95$ & 89.0 & 78 & 8 & 1.0 & 1.0 & 1.1 & .11 & 7.7 & 11.0 & 21 & 2.1 & 70 \\
\hline $114+85$ & 89.0 & 80 & 8 & 1.0 & 1.0 & 1.1 & .12 & 7.5 & 9.0 & 21 & 2.1 & 73 \\
\hline \multicolumn{13}{|c|}{ U.S. Highway 165 , Jackson Street } \\
\hline $106+62$ & 90.0 & 60 & 5 & 1.0 & 1.0 & 1.1 & .11 & 8.9 & 30.0 & 22 & 3.5 & 52 \\
\hline $108+15^{2}$ & 90.0 & 30 & 25 & 1.0 & 1.0 & 1.1 & .18 & 35.9 & 60.0 & 99 & 8.0 & -6 \\
\hline $111+47$ & 90.0 & 50 & 25 & 1.0 & 1.0 & 1.1 & .23 & 34.4 & 40.0 & 95 & 8.2 & 16 \\
\hline $113+08$ & 90.0 & 85 & 5 & 1.0 & 1.0 & 1.1 & .17 & 5.1 & 5.0 & 14 & 2.1 & 80 \\
\hline $113+90$ & 90.0 & 80 & 5 & 1.0 & 1.0 & 1.1 & .12 & 5.6 & 10.0 & 15 & 2.1 & 74 \\
\hline $114+70$ & 90.0 & 79 & 5 & 1.0 & 1.0 & 1.1 & .11 & 5.6 & 11.0 & 16 & 2.1 & 73 \\
\hline \multicolumn{13}{|c|}{ U.S. Highway 71, O.K. Allen Bridge } \\
\hline $114+25$ & 91.0 & 70 & 12 & 1.0 & 1.0 & 1.1 & .08 & 10.1 & 21.0 & 28 & 2.2 & 60 \\
\hline $119+26$ & 91.0 & 37 & 12 & 1.0 & 1.0 & 1.1 & .23 & 21.6 & 54.0 & 59 & 9.6 & 15 \\
\hline $120+88$ & 91.0 & 82 & 12 & 1.0 & 1.0 & 1.1 & .07 & 6.9 & 9.0 & 19 & 1.2 & 75 \\
\hline $121+91$ & 91.0 & 80 & 12 & 1.0 & 1.0 & 1.1 & .06 & 7.1 & 11.0 & 20 & 1.2 & 73 \\
\hline $122+93$ & 91.0 & 80 & 12 & 1.0 & 1.0 & 1.1 & .06 & 7.1 & 11.0 & 20 & 1.2 & 73 \\
\hline
\end{tabular}

${ }^{1}$ Numbers are rounded to the nearest foot.

${ }^{2}$ Pier armored with riprap, scour estimate is for the condition with no riprap in place. 


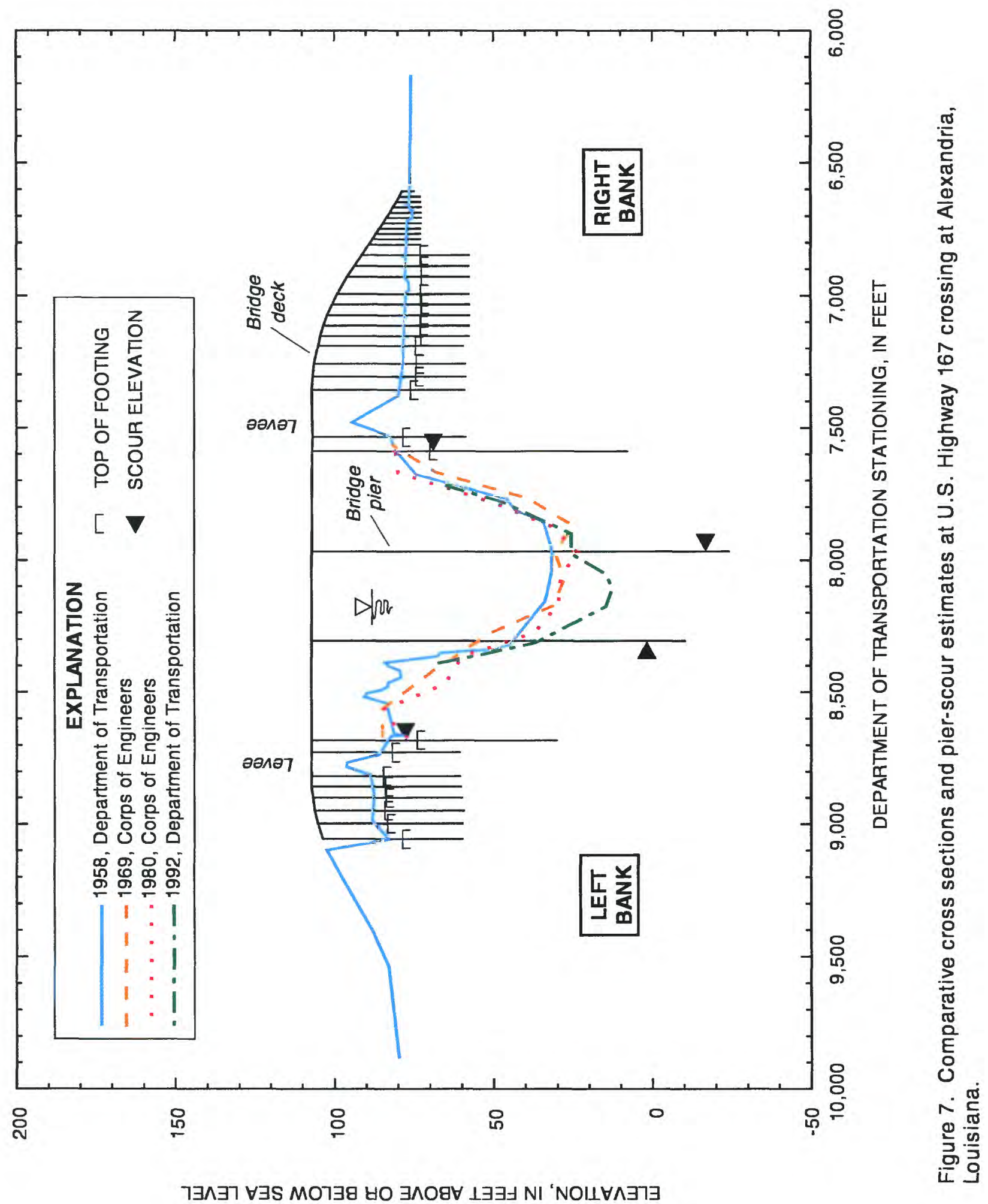




\section{U.S. Highway 167 (Proposed) at Alexandria, Louisiana}

\section{Pier Scour}

To evaluate pier scour at the proposed U.S. Hwy. 167 bridge, values for $y_{1}$ at each pier were based on the DOTD hydrographic survey of 1992 . The cross section is the deepest of the sections shown in figure 8. The cross section represents the largest change in channel geometry when compared to the three previc'is surveys performed over an 18-year period.

The right overbank pier at DOTD station 103+09, had an estimated scour depth of $9.0 \mathrm{ft}$, which corresponds to a channel-bed elevation of $72 \mathrm{ft}$ above sea level (fig. 8, table 4). The greatest scour depth estimated was $21.7 \mathrm{ft}$ for the pier at DOTD station $107+31$, which corresponds to a bed elevation of $2 \mathrm{ft}$ above sea level. This elevation is slightly lower than the pile-cap elevations shown on the DOTD bric'ge plans. The left overbank piers at DOTD stations $113+06,113+95$, and 114+85 have estimated scour depths between 6 and $8 \mathrm{ft}$.

\section{Channel Stability}

Cross sections prepared from hydrographic surveys of 1986, 1969, and 1980 (fig. 8) do not indicate any substantial trends or changes in the channel at the proposed bridge. The survey performed by DO...D in 1992 indicates a deepening of the thalweg, resulting in maximum channel-bed elevation decreases of about $8 \mathrm{ft}$. The minimum bed elevation from the 1980 and prior surveys is approximately $24 \mathrm{ft}$ above sea level. The minimum bed elevation from the 1992 survey is approximately $12 \mathrm{ft}$ above sea level.

\section{U.S. Highway 165 at Alexandria, Louisiana}

\section{Pier Scour}

To evaluate pier scour at U.S. Hwy. 165, values for $\mathrm{y}_{1}$ at each pier were based on the COE hydrographic survey of 1969 . The cross section used in the analysis of U.S. Hwy. 165 closely resembles, and is slightly lower than the cross section from the COE and DOTD hydrographic surveys of 1980 (fig. 9). The right overbank pier at DOTD station $106+62$, had an estimated scour depth of $8.9 \mathrm{ft}$, which corresponds to a channel-bed elevation of $52 \mathrm{ft}$ above sea level (table 4). The greatest scour depth estimated was $35.9 \mathrm{ft}$ at the right main pier (DOTD station 108+15), which corresponds to a channel-bed elevation of $6 \mathrm{ft}$ below sea level, which is below the pile-cap elevation. Bridge plans indicate riprap protection at this pier which was not considered in the scour estimate. If this riprap is maintained, no substantial scouring is anticipated. Scour at the left main pier at DOTD station $111+47$ is estimated at $34.4 \mathrm{ft}$, resulting in a channel-red elevation of $16 \mathrm{ft}$ above sea level, which is near the pile-cap elevation. The left overbank piers at DOTD stations $113+08,113+90$, and $114+70$ had computed scour depths ranging from $5.1 \mathrm{ft}$ at the riverward pier to $5.6 \mathrm{ft}$ at the landward pier. The estimated channel-bed elevations of the scour holes range from 73 to 80 $\mathrm{ft}$ above sea level. 


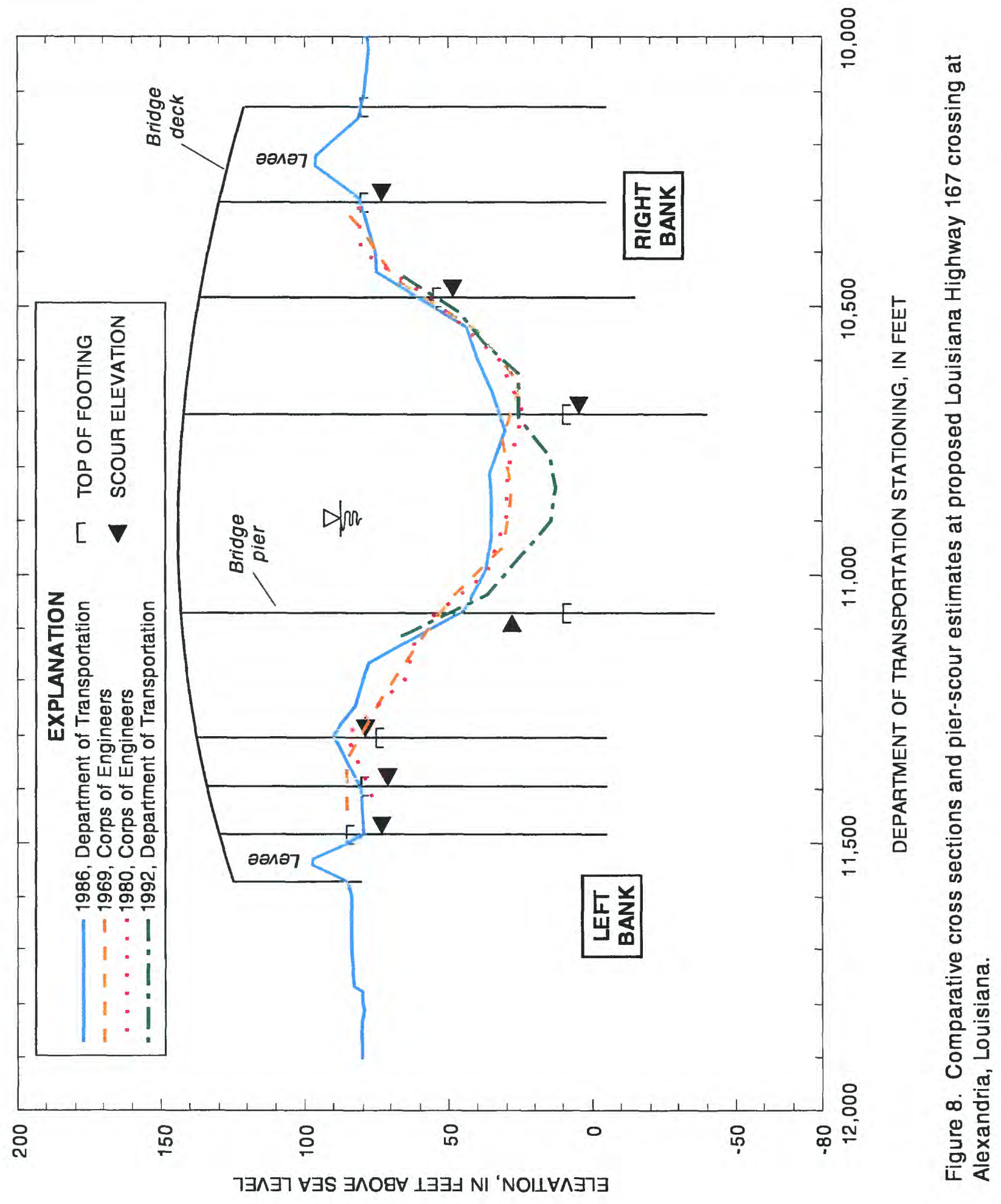




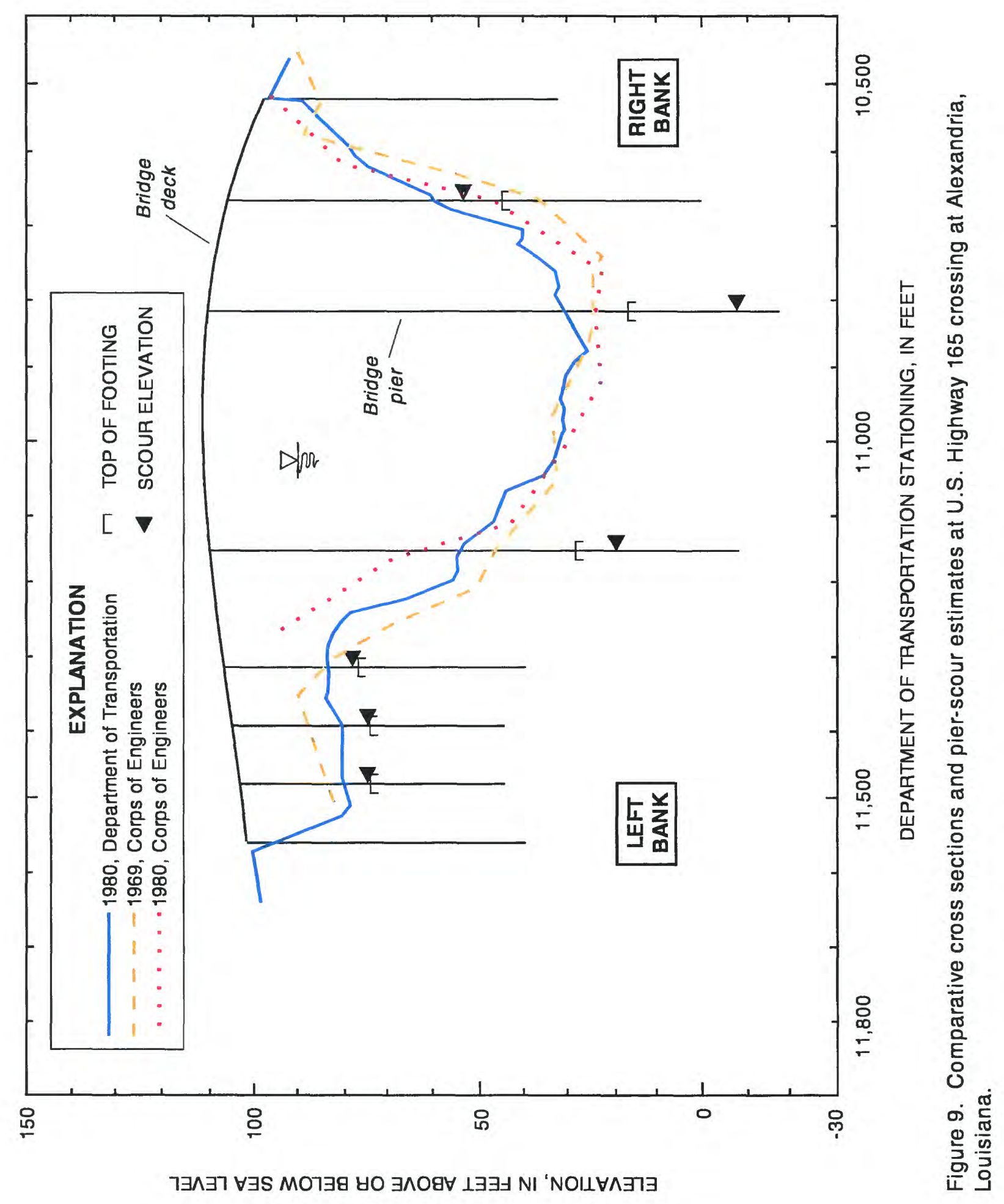




\section{Channel Stability}

Hydrographic surveys of 1969 and 1980 at the U.S. Hwy. 165 bridge do not indicate any substantial trends or changes in the channel. The lowest channel-bed elevations occur at the right main pier of the bridge. The differences indicated between the COE and DOTD surveys of 1980 can be attributed to mincr differences in where the cross section was measured. The DOTD survey is performed at the highway crossing, and the COE cross section is a surveyed cross section nearest to the bridge location. The channel-bed elevations from the surveys range from 21 to $25 \mathrm{ft}$ above sea level. The top of the footing at the right main pier is $18 \mathrm{ft}$ above sea level. The layer of bed material covering the right main pier footing appears stable from the hydrographic information, but the scour estimates from the previous paragraph indicate the potential removal of this material, exposing the footing. Aerial photographs taken in 1977 ant 1987 (figs. 10 and 11) show no substantial changes of alignment.

\section{U.S. Highway 71 at Alexandria, Louisiana}

\section{Pier Scour}

To evaluate pier scour at U.S. Hwy. 71, values for $y_{1}$ at each pier were based on the DOTD hydrographic survey of 1992. The cross section represented by the 1992 DOTD survey indicates decrease-1 channel-bed elevations near the right main pier (fig. 12). Values for $K_{1}=1.0, K_{2}=1.0$, and $K_{3}=1.1$ were based on DOTD bridge plans and recommendations presented by Richardson and others (1993, p. 39-40). The Froude number at the pier location is based upon the value of velocity, which was computed using WSPRO.

The maximum computed pier scour depth was $21.6 \mathrm{ft}$ at the right main pier (DOTD station 119+26) (table 4). The elevation of the bed at the computed scour hole is $15 \mathrm{ft}$ above sea level. The elevation of the top of the footing for this pier is $35 \mathrm{ft}$ above sea level. This scour estimate is well below the designed top of footing. The left main pier is at DOTD station $114+25$, where channel-bed elevations are higher than at the right main pier. The scour depth for the left main pier is $10.1 \mathrm{ft}$, and the elevation of the bed of the scorr hole is $60 \mathrm{ft}$ above sea level. The left overbank piers are above the water surface for the 500 -year floot estimate, consequently no scour computations were performed for the left overbank piers. There are three piers on the right bank at DOTD stations $120+88,121+91$ and $122+93$. For these three piers the scour depths range from 6.9 to $7.1 \mathrm{ft}$, and the corresponding channel-bed elevations of the estimated scour holes range from 73 to $75 \mathrm{ft}$ above sea level.

\section{Channel Stability}

The hydrographic surveys of 1968 and 1980 show little dynamic activity of the river bed (fig. 12); however, the DOTD hydrographic survey of 1992 indicates a deepening and migration of the thalweg towards the right bank. This most recent survey indicates channel-bed elevations are below the top of the right-bank main-pier footing. Based on this information, the pier is at a higher risk of failure than the other piers at this site. Aerial photographs taken in 1977 and 1987 (figs. 13 and 14) were taken at low-water conditions and indicate no alignment changes. 


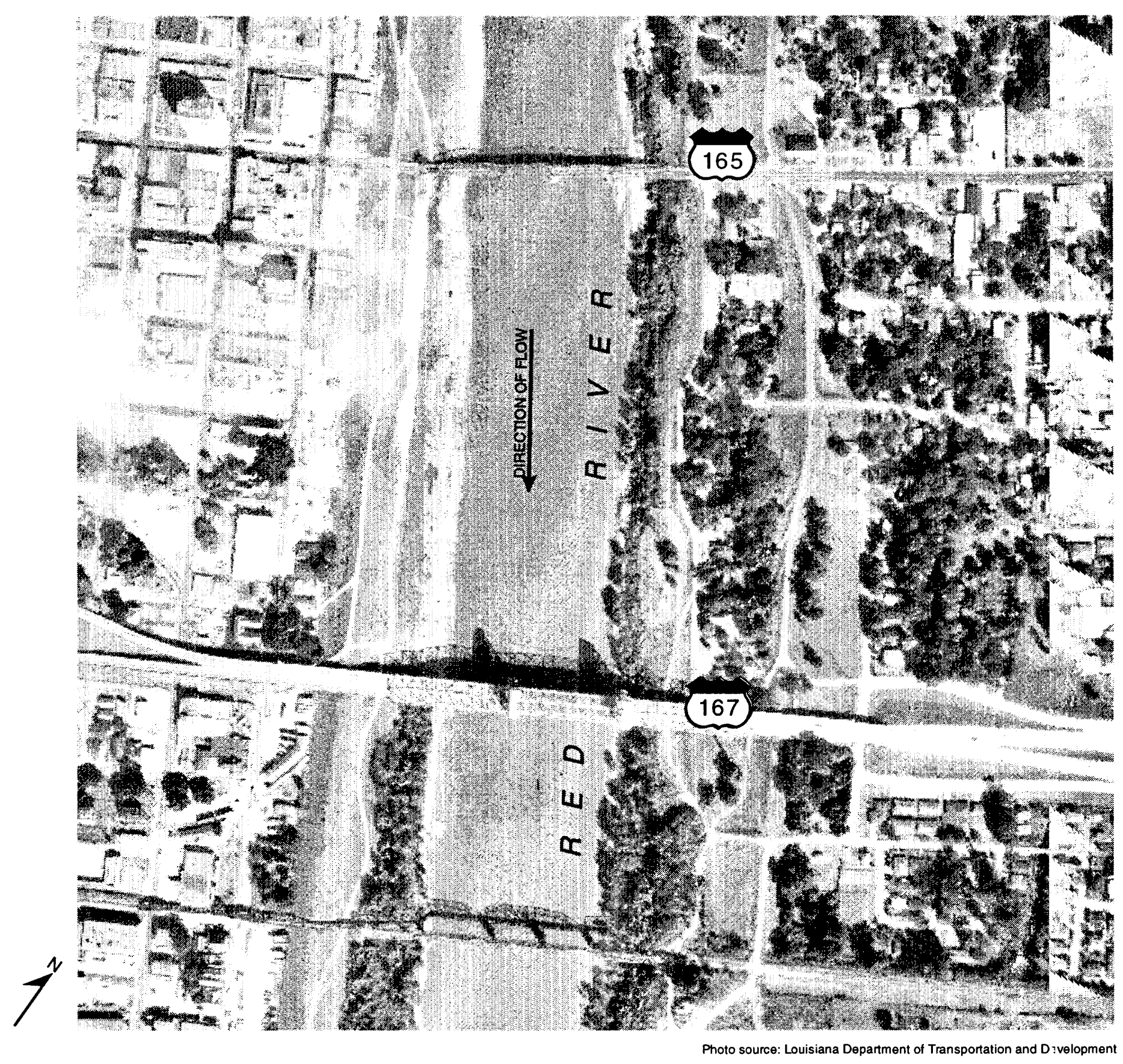

Figure 10. Aerial photograph of the U.S. Highways 165 and 167 crossings of the Red River at Alesandria, Louisiana, August 8, 1977. 


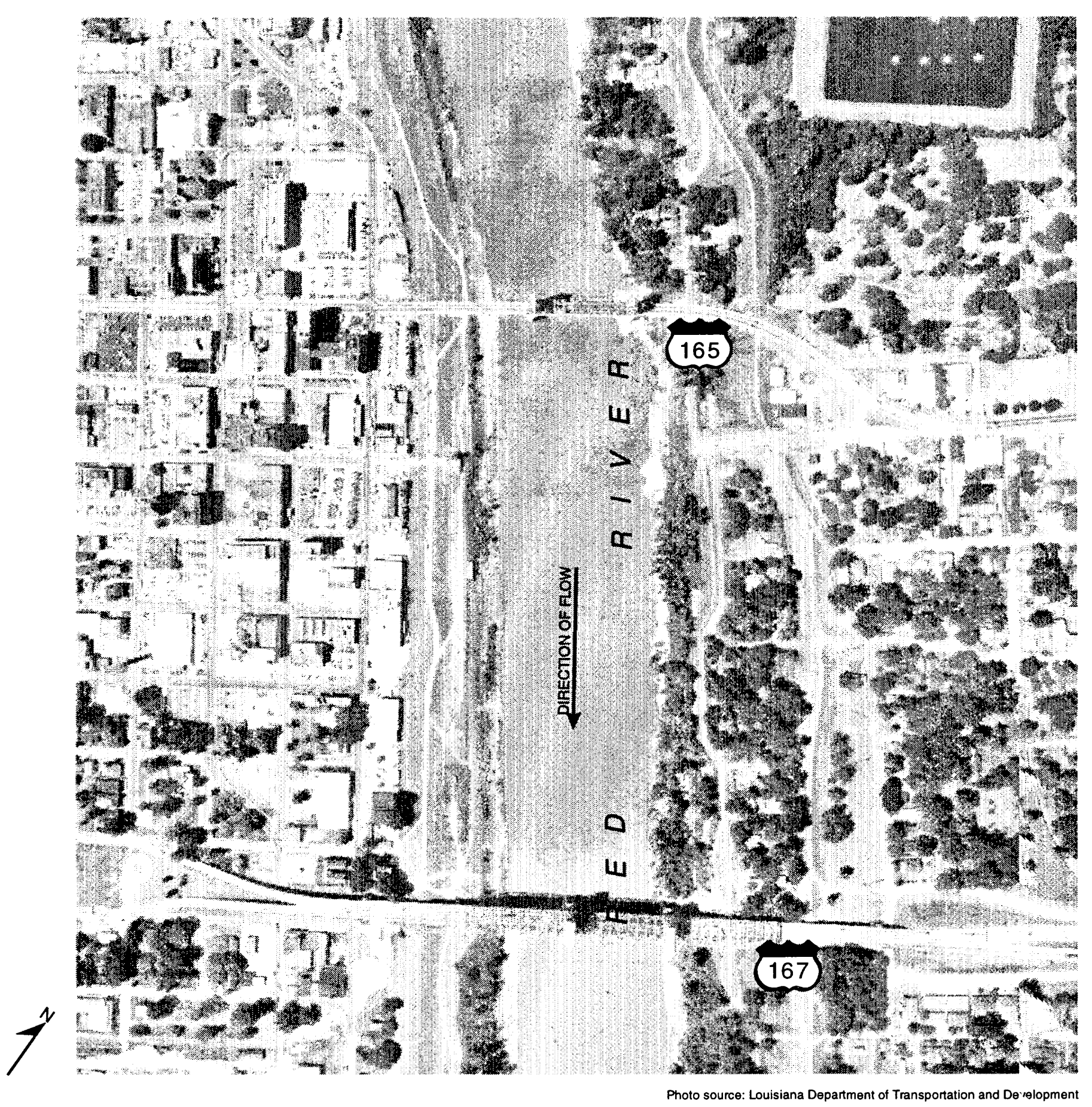

Figure 11. Aerial photograph of the U.S. Highways 165 and 167 crossings of the Red River at f'exandria, Louisiana, October 5, 1987. 


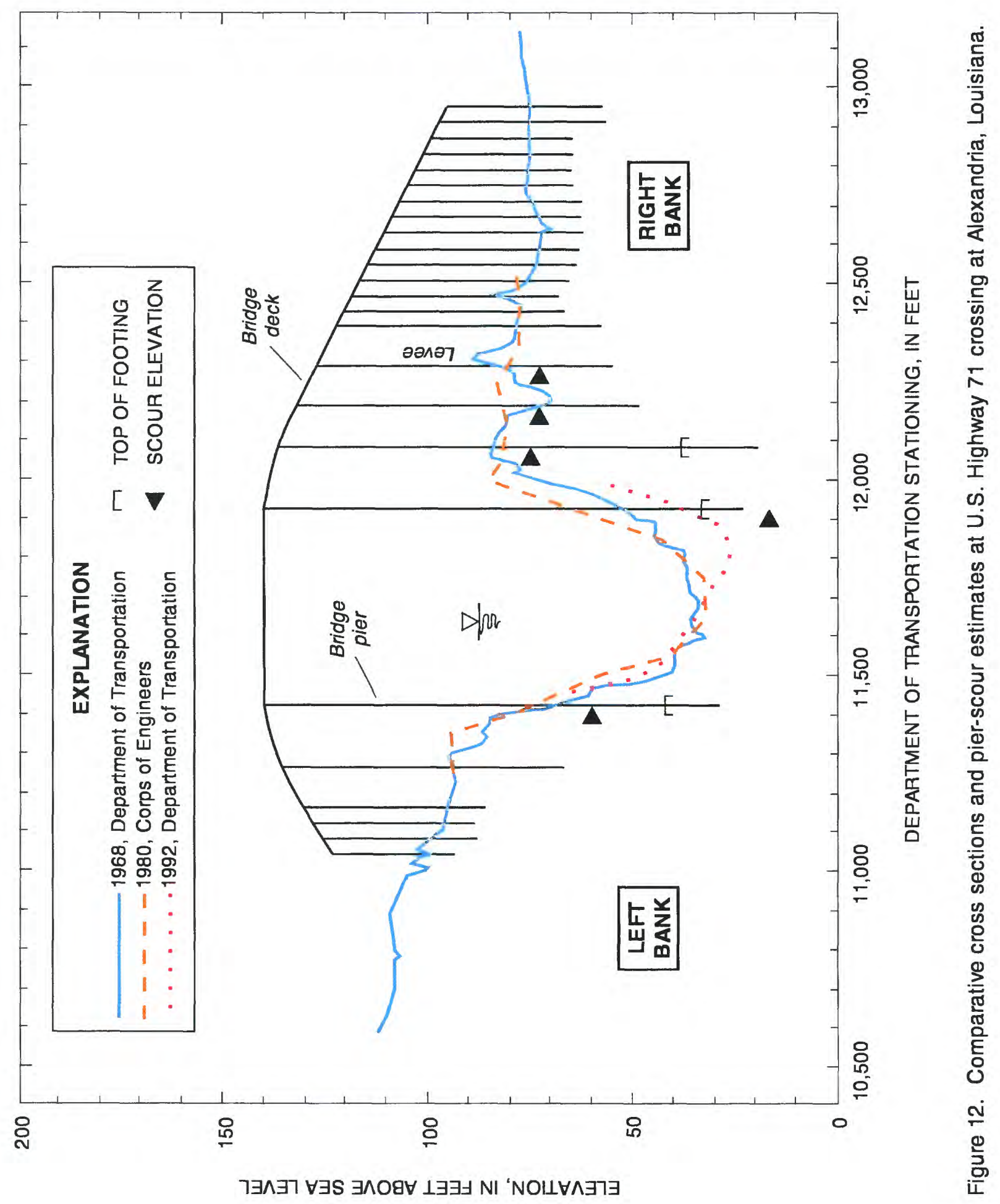




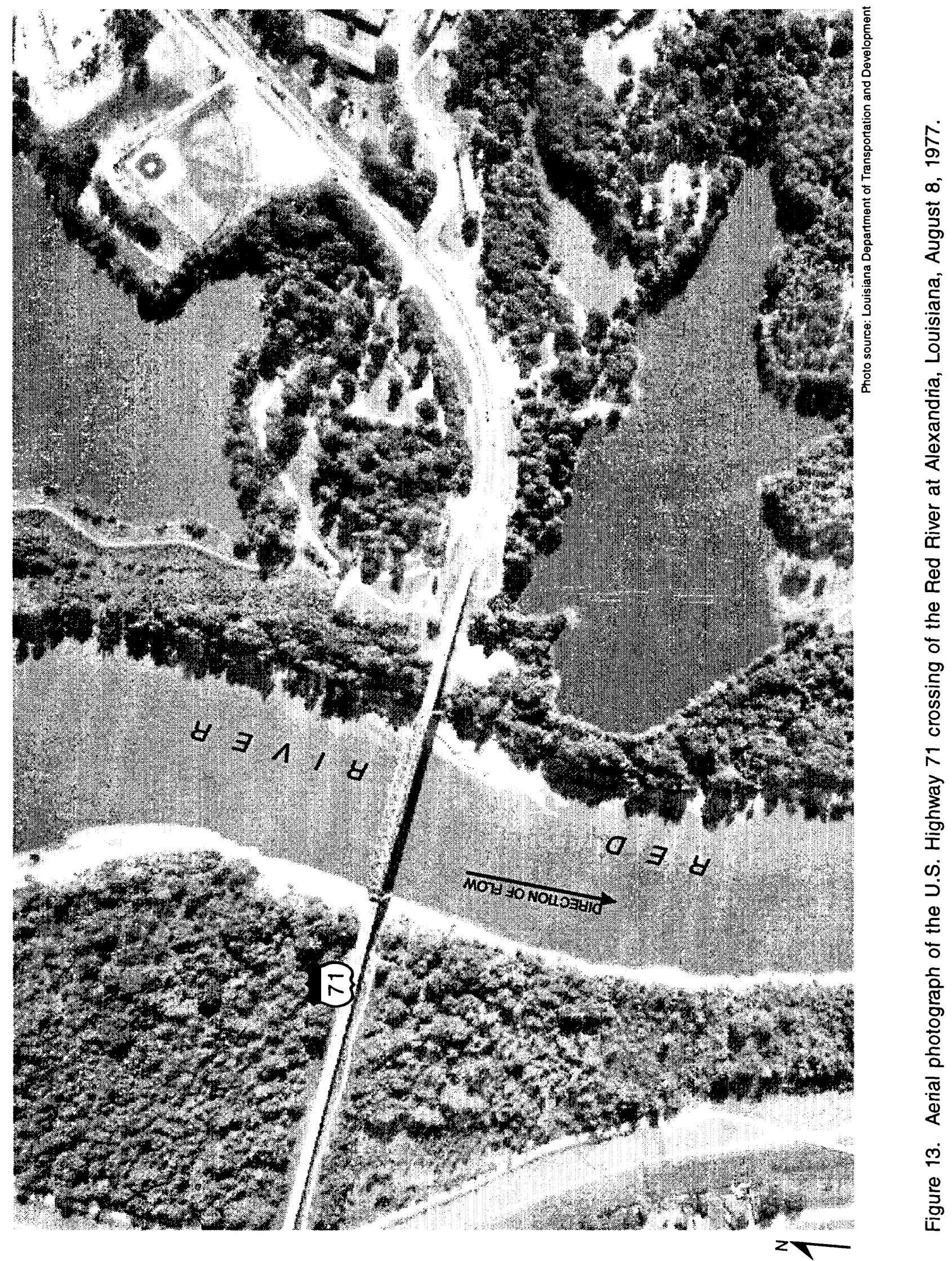




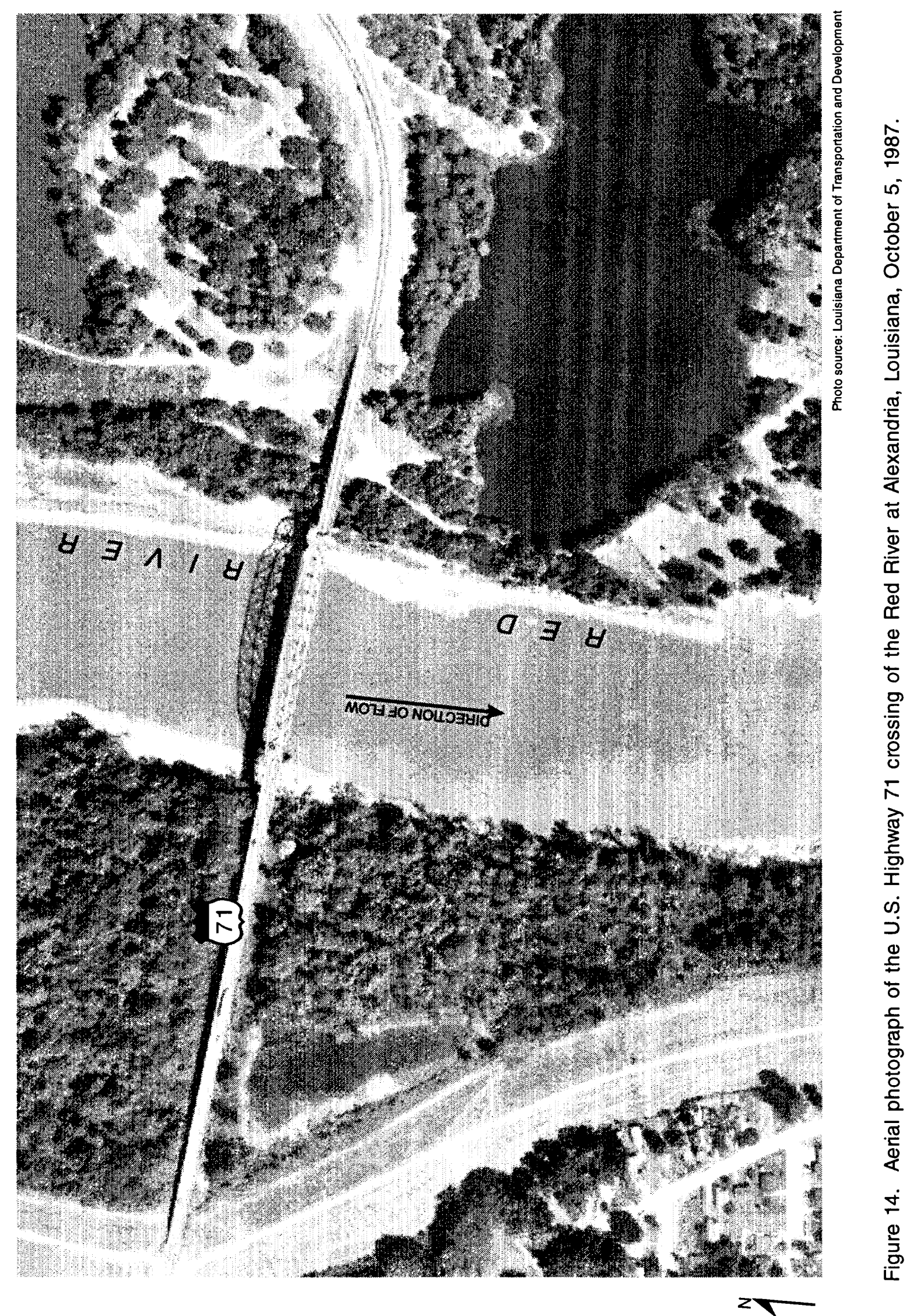




\section{Louisiana Highway 8 at Boyce, Louisiana}

Flood-frequency estimates based on the regression shown in figure 7 were used for the hydrauli? analysis. The 500 -year flood estimate is $260,500 \mathrm{ft}^{3} / \mathrm{s}$ (table 1). Boundary condition and roughness coefficient variables used in WSPRO were based on simulations that were calibrated to peak discharges at other sites along the Red River. The computed water-surface elevation resulting from hydraulic simulation $\mathrm{s}$ using the 500-year flood estimate was $97 \mathrm{ft}$ above sea level (table 5). The model reach for evaluation of the La. Hwy. 8 bridge extends from about $5,000 \mathrm{ft}$ downstream to 2,000 ft upstream of the highway crossing. The width of the channel at the 500-year flood estimate ranges from 1,500 to 2,450 $\mathrm{ft}$ throughout the. reach. The minimum channel-bed elevations for cross sections in the reach ranged from 30 to $44 \mathrm{ft}$ above sea level. The starting downstream boundary condition for computations using WSPRO was a slope $c^{f}$ 0.0001 , which is the same slope used in the calibration simulations. The 500 -year flood estimates indicate velocities ranging from 2.3 to $8.1 \mathrm{ft} / \mathrm{s}$ along the cross section at the bridge (table 5).

Table 5. Pier-scour estimates for Louisiana Highway 8 crossing the Red River at Boyce, Louisiana

[DOTD, Louisiana Department of Transportation and Development; WSE, water-surface elevation, in feet above sea level; GSE, ground-surface (channel-bed) elevation, in feet above sea level; $a$, width of pier, in feet; $K_{1}$, dimensionless correction factor for pier nose shape; $K_{2}$, dimensionless correction factor for angle of flow attack; $K_{3}$, dimensionless correction factor for channel-bed condition; Fr, Froude number computed at the location; $y_{S}$, estimated depth of pier scour, in feet; $y_{1}$, flow depth directly upstream of the pier, in feet; Tw, estimated top width of the scour hole, in feet; $V$, velocity computed for that locaticn in the cross section, in feet per second; $y_{d}$, channel-bed elevation of the computed scour hole, in feet above sea level]

\begin{tabular}{|c|c|c|c|c|c|c|c|c|c|c|c|c|}
\hline $\begin{array}{l}\text { DOTD } \\
\text { station }\end{array}$ & WSE & GSE & $\mathbf{a}$ & $\mathbf{K}_{1}$ & $\mathbf{K}_{2}$ & $\mathbf{K}_{\mathbf{3}}$ & $\mathbf{F r}$ & $y_{s}$ & $\mathbf{y}_{1}$ & Tw & $\mathbf{v}$ & $y_{d}^{1}$ \\
\hline \multicolumn{13}{|c|}{ Right overbank pier } \\
\hline $138+40$ & 97.0 & 90 & 7 & 1.0 & 1.0 & 1.1 & 0.17 & 7.6 & 8.0 & 21 & 2.8 & 82 \\
\hline \multicolumn{13}{|c|}{$\underline{\text { Right main pier }}$} \\
\hline $141+40^{2}$ & 97.0 & 50 & 7 & 1.0 & 1.0 & 1.1 & .19 & 14.3 & 43.0 & 39 & 7.2 & 41 \\
\hline \multicolumn{13}{|c|}{ Main channel pier } \\
\hline $144+50^{2}$ & 97.0 & 45 & 7 & 1.0 & 1.0 & 1.1 & .20 & 15.5 & 53.0 & 43 & 8.1 & 29 \\
\hline \multicolumn{13}{|c|}{ Left main channel pier } \\
\hline $148+20$ & 97.0 & 80 & 7 & 1.0 & 1.0 & 1.1 & .10 & 7.8 & 18.0 & 21 & 2.3 & 72 \\
\hline \multicolumn{13}{|c|}{ Left overbank pier } \\
\hline $151+80$ & 97.0 & 88 & 7 & 1.0 & 1.0 & 1.1 & .13 & 7.2 & 10.0 & 20 & 2.3 & 81 \\
\hline
\end{tabular}

\footnotetext{
${ }^{1}$ Numbers are rounded to the nearest foot.

${ }^{2}$ Pier armored with riprap, scour estimate is for the condition with no riprap in place.
} 


\section{Pier Scour}

For evaluation of pier scour at La. Hwy. 8, values for $\mathrm{y}_{1}$ at each pier were based on the COS hydrographic survey of 1969 . The cross section represented by the 1969 survey represents a fairly uniform section and represents the lowest elevations for sections based on the historic cross-section information at the site (fig. 15). Other surveys at this site indicate minor changes in the minimum channel-bed elevation, but with no substantial movement of the thalweg. Values for $\mathrm{K}_{1}=1.0, \mathrm{~K}_{2}=1.0$, and $\mathrm{K}_{3}=1.1$ were based on DOTD bridge plans and recommendations presented by Richardson and others (1993, p. 39-40). The Froude number at the pier location is based upon the value of velocity, which was computed using WSPRO (table 5). The maximum computed scour depth was $15.5 \mathrm{ft}$ for the pier at DOTD station 144+50. The elevation of the bed of the computed scour hole is approximately $29 \mathrm{ft}$ above sea level. The two piers in the main channel at DOTD stations $141+40$ and $144+50$ are protected from scouring by stone riprap according to the design plans. The Colorado State University pier-scour equation recommended by Richardson an 1 others $(1991,1993)$ is for cohesionless sand-bed streams, not for locations armored with large stone material such as riprap. For this reason, estimates of pier scour for locations with riprap protection are shown for information purposes only. For the pier at DOTD station $144+50$, the riprap is part of a rock dike, which is visible from aerial photographs (figs. 16 and 17). The riprap protection for the pier at DOTD station $141+5$ ? is unconfirmed by information collected for this evaluation, and the presence of the riprap material is assumed, based solely on the bridge plan drawings.

\section{Channel Stability}

To evaluate channel stability at the La. Hwy. 8 crossing of the Red River, cross-section information is available for the years 1969 and 1980 . Two surveys are shown in figure 15 for 1980, one performed by the COE and one by DOTD. The differences in the 1980 cross sections can be attributed to minor differences in the location at which the cross section was measured and the potential error in recovering the 1969 elevation information from map sources. All three surveys represent the same general cross-section geometry. The stone riprap protection, which is part of a rock dike around the pier at DOTD station $144+50$, is indicated only from the 1980 survey performed by DOTD. The protection around the pier is visible on aerial photographs taken in 1986 and 1987 (figs. 16 and 17). The 1987 photograph was taken during a lower river stage than when the 1986 photo was taken and parts of the rock dike are visible. Although no observable channel migration appears in the photographs, higher channel-bed elevations are noted behind the lines of timber piles on the right bank. These higher elevations may be due to deposition behind the flow-directing timber structures.

\section{Louisiana Highway 6 at Grand Ecore, Louisiana}

Flood-frequency estimates based on the data shown in figure 3 were used for the hydraulic analys is at La. Hwy. 6. The 500-year flood estimate is $302,500 \mathrm{ft}^{3} / \mathrm{s}$ (table 1). Hydraulic simulations were calibrated to a peak discharge of $224,000 \mathrm{ft}^{3} / \mathrm{s}$, with a water-surface elevation of about $115.0 \mathrm{ft}$ above sea level. Tre computed water-surface elevation resulting from hydraulic simulations using the 500 -year flood estimate was about $120.0 \mathrm{ft}$ above sea level (table 6).

The model reach for evaluation of the La. Hwy. 6 bridge extends from about 1,000 ft upstream to $3,900 \mathrm{ft}$ downstream of the highway crossing. The width of the channel at the design discharge ranges from 1,100 to $2,704 \mathrm{ft}$ throughout the reach. The minimum channel-bed elevations for cross sections in the reach ranged from 64 to $77 \mathrm{ft}$ above sea level. The downstream boundary condition for computations using WSPRO was a slope of 0.0001 , for both the calibration simulations and the 500-year flood estimate simulation. The 500-year flood estimate simulation indicates velocities ranging from 9.8 to $12.0 \mathrm{ft} / \mathrm{s}$ along the cross section at the bridge. 


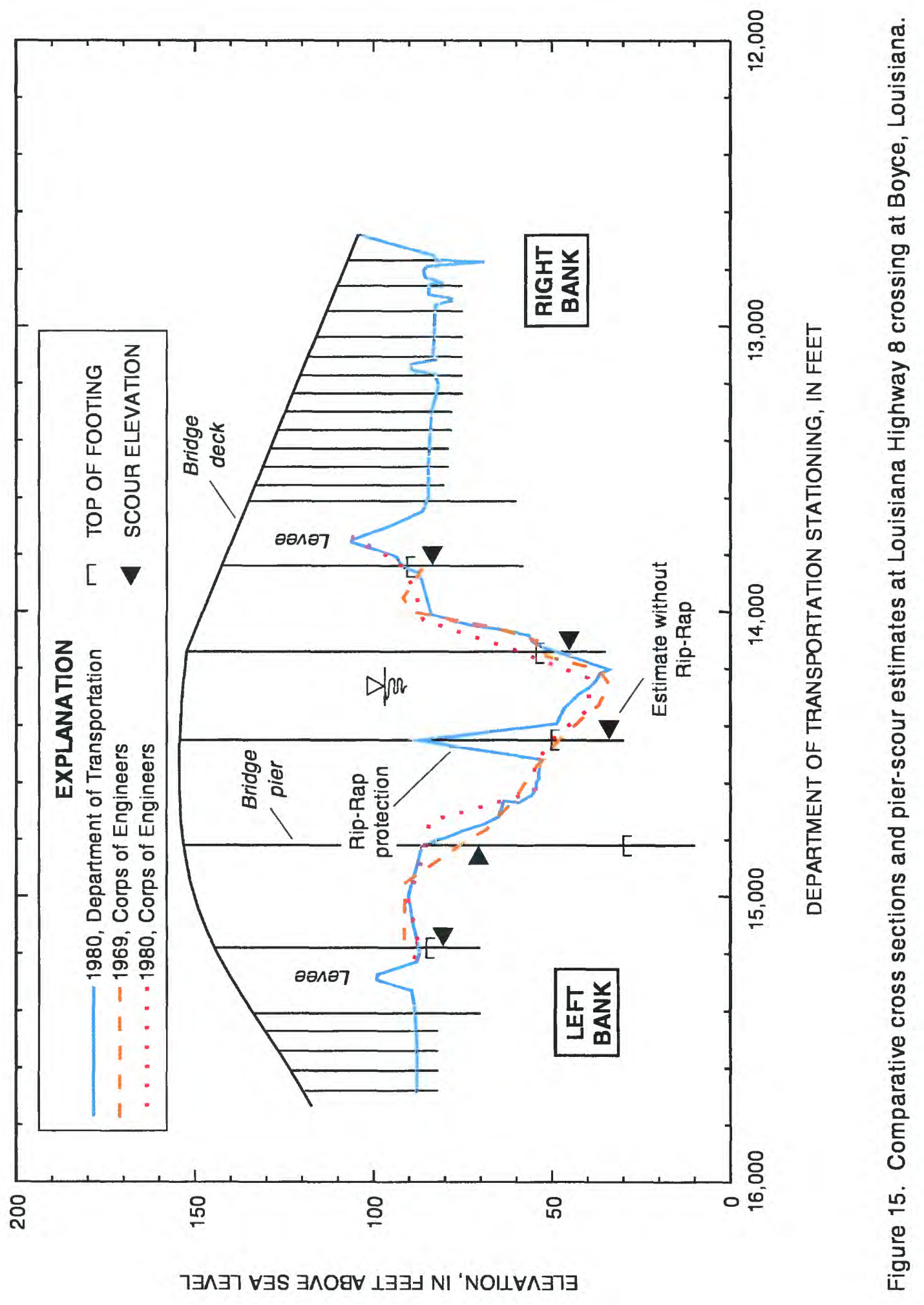




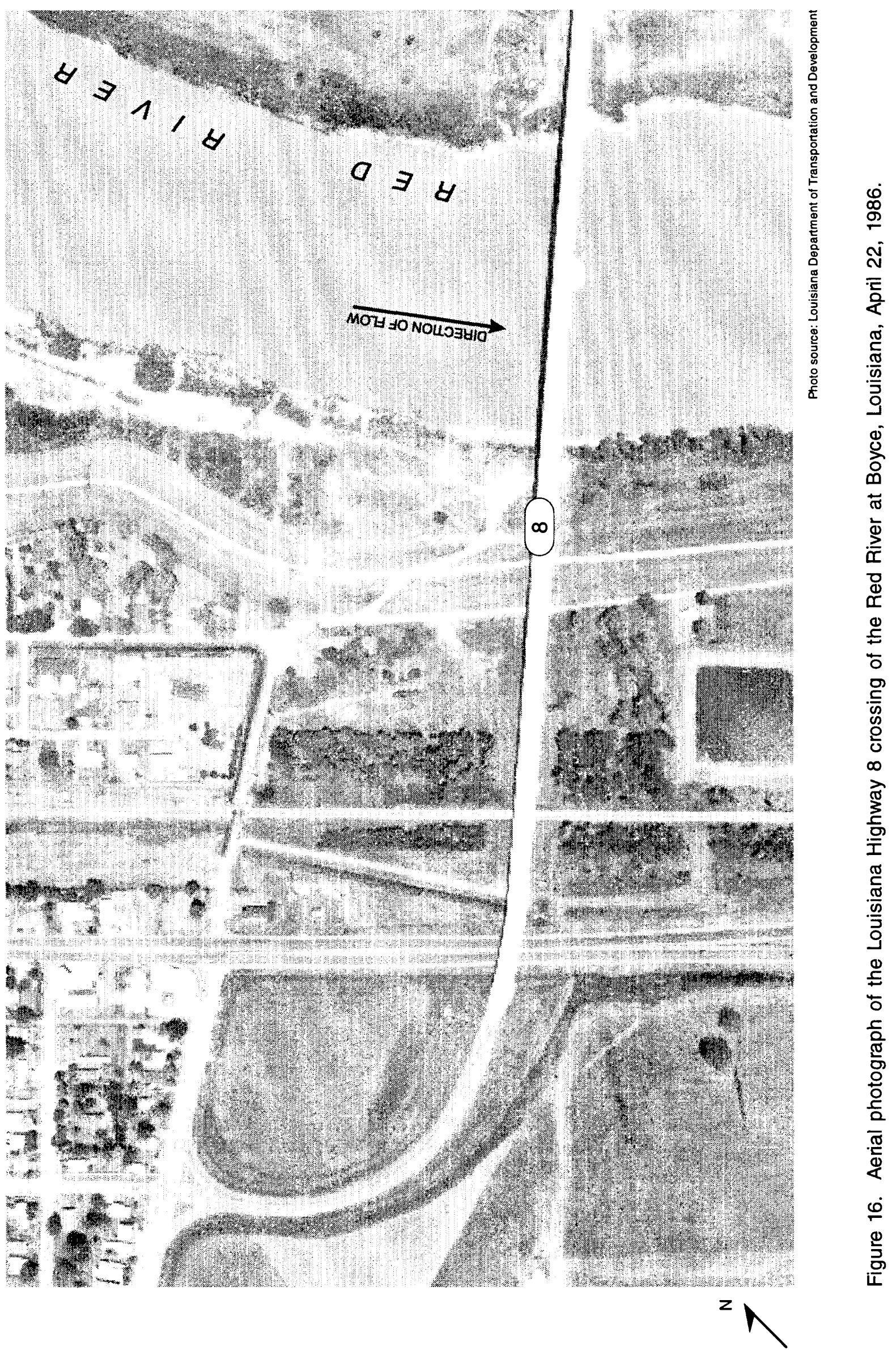




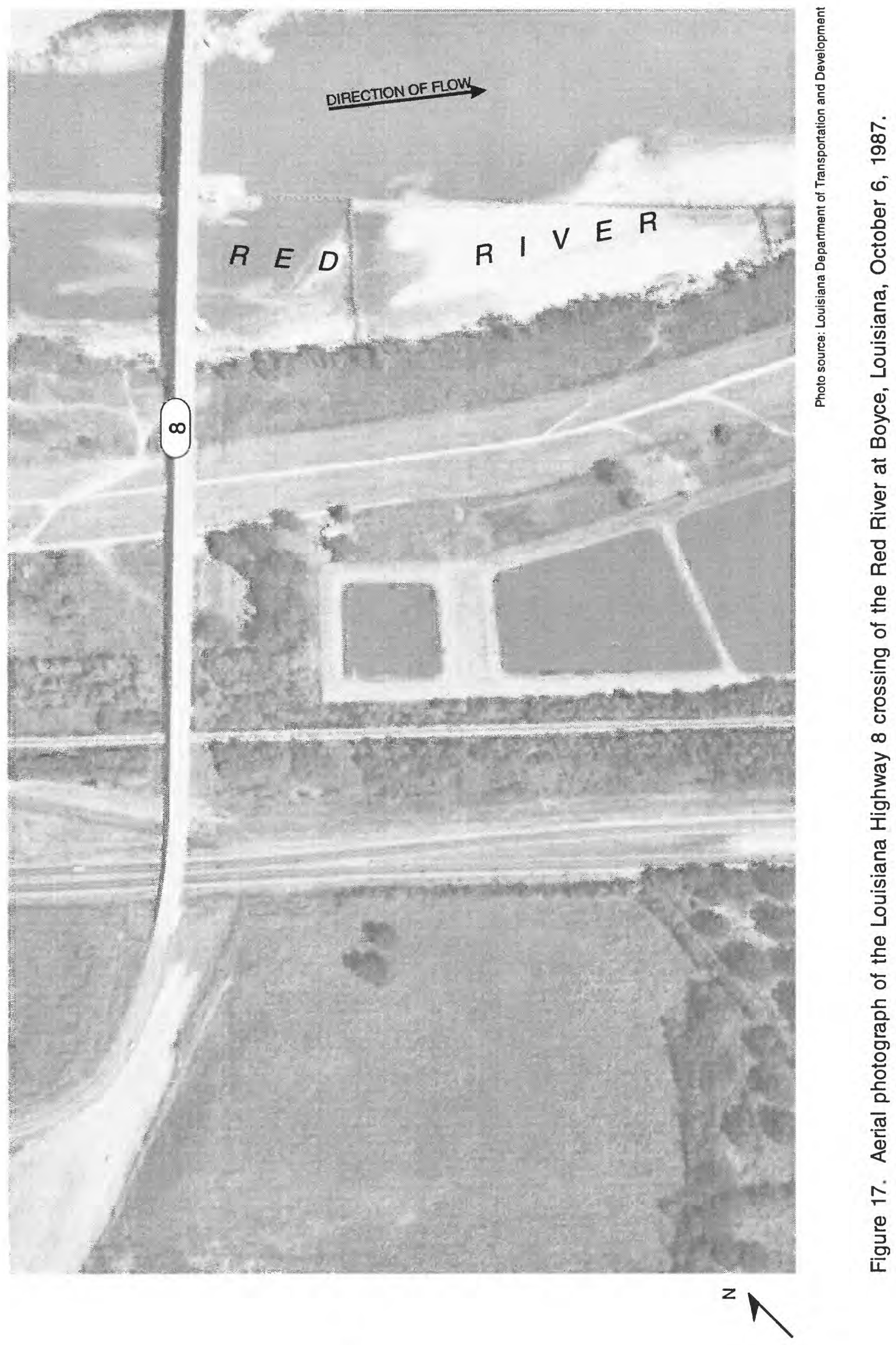


Table 6. Pier-scour estimates for Louisiana Highway 6 crossing the Red River at Grand Ecore, Louisiana

[DOTD, Louisiana Department of Transportation and Development; WSE, water-surface elevation, in feet above sea level; GSE, ground-surface (channel-bed) elevation, in feet above sea level; a, width of pier, in feet; $\mathrm{K}_{1}$, dimensionless correction fartor for pier nose shape; $\mathrm{K}_{2}$, dimensionless correction factor for angle of flow attack; $\mathrm{K}_{3}$, dimensionless correction factor for channel-bed condition; Fr, Froude number computed at the location; $y_{S}$, estimated depth of pier scour, in feet; $y_{1}$, flow depth directly upstream of the pier, in feet; Tw, estimated top width of the scour hole, in feet; $V$, velocity computed for that location in the cross section, in feet per second; $y_{d}$, channel-bed elevation of the computed scour hole, in feet above sea level]

\begin{tabular}{|c|c|c|c|c|c|c|c|c|c|c|c|c|}
\hline $\begin{array}{l}\text { DOTD } \\
\text { station }\end{array}$ & WSE & GSE & a & $\mathbf{K}_{1}$ & $\mathbf{K}_{2}$ & $\mathbf{K}_{3}$ & $\mathrm{Fr}$ & $y_{s}$ & $y_{1}$ & Tw & $\mathbf{v}$ & $y_{d}^{1}$ \\
\hline \multicolumn{13}{|c|}{ Right main channel } \\
\hline $190+89$ & 120.0 & 66 & 20 & 1.0 & 1.0 & 1.1 & 0.29 & 36.5 & 54.0 & 100 & 12.0 & 30 \\
\hline \multicolumn{13}{|c|}{ Left main channel pier } \\
\hline $194+64$ & 120.0 & 84 & 20 & 1.0 & 1.0 & 1.1 & .29 & 31.6 & 36.0 & 87 & 9.8 & 52 \\
\hline
\end{tabular}

${ }^{1}$ Numbers are rounded to the nearest foot.

\section{Pier Scour}

For evaluation of pier scour at La. Hwy. 6, values for $\mathrm{y}_{1}$ at each pier were based on the DOTD hydrographic survey of 1990 . The cross section represented by this survey represents a fairly uniform section, and generally agrees with the section from the survey of 1967 (fig. 18). The survey of $19^{\circ} 8$ indicates lowering of the minimum channel-bed elevation, but no significant lateral movement of the thalweg. If those conditions reoccur periodically, the estimate of scour may need reevaluation. Values for $\mathrm{K}_{1}=1.0, \mathrm{~K}_{2}=1.0$, and $\mathrm{K}_{3}=1.1$ were based on DOTD bridge plans and recommendations presented by Richardson and others (1993, p. 39-40). The Froude number at the pier location is based upon the value of velocity, which was computed using WSPRO.

The maximum computed pier scour depth was $36.5 \mathrm{ft}$ for the pier at DOTD station 190+89. T"a elevation of the bed of the computed scour hole is $30 \mathrm{ft}$ above sea level. The only other pier subject to scc rur at this site is at DOTD station $194+64$. The computed scour depth at this pier is $31.6 \mathrm{ft}$ with a channel-b:d elevation of $52 \mathrm{ft}$ above sea level (table 6). All other piers (fig. 18) are in locations where the ground surfare is above the 500 -year flood estimate.

\section{Channel Stability}

To evaluate channel stability at La. Hwy. 6, cross-section information is available for the years 1967 , 1988, and 1990. The lowest and highest channel-bed elevations are indicated by the 1967 and 1988 surveys, respectively. The changes in the thalweg elevation (fig. 18) may be the natural response of the river bed to variations in flow magnitudes.

Aerial photographs of the bridge crossing for 1977 and 1988 (figs. 19 and 20) do not show any significant migration of the channel. The more recent photograph was taken at a lower river stage than the previous photograph and shows a sand bank on the left bank. This sand bank is not the result of deposition, but is simply the channel bed, which is exposed due to the lower river stage. The right bank is very steep, and is on the outside of a curve in the river. The bank is composed of consolidated clay materials and ras remained stable. 


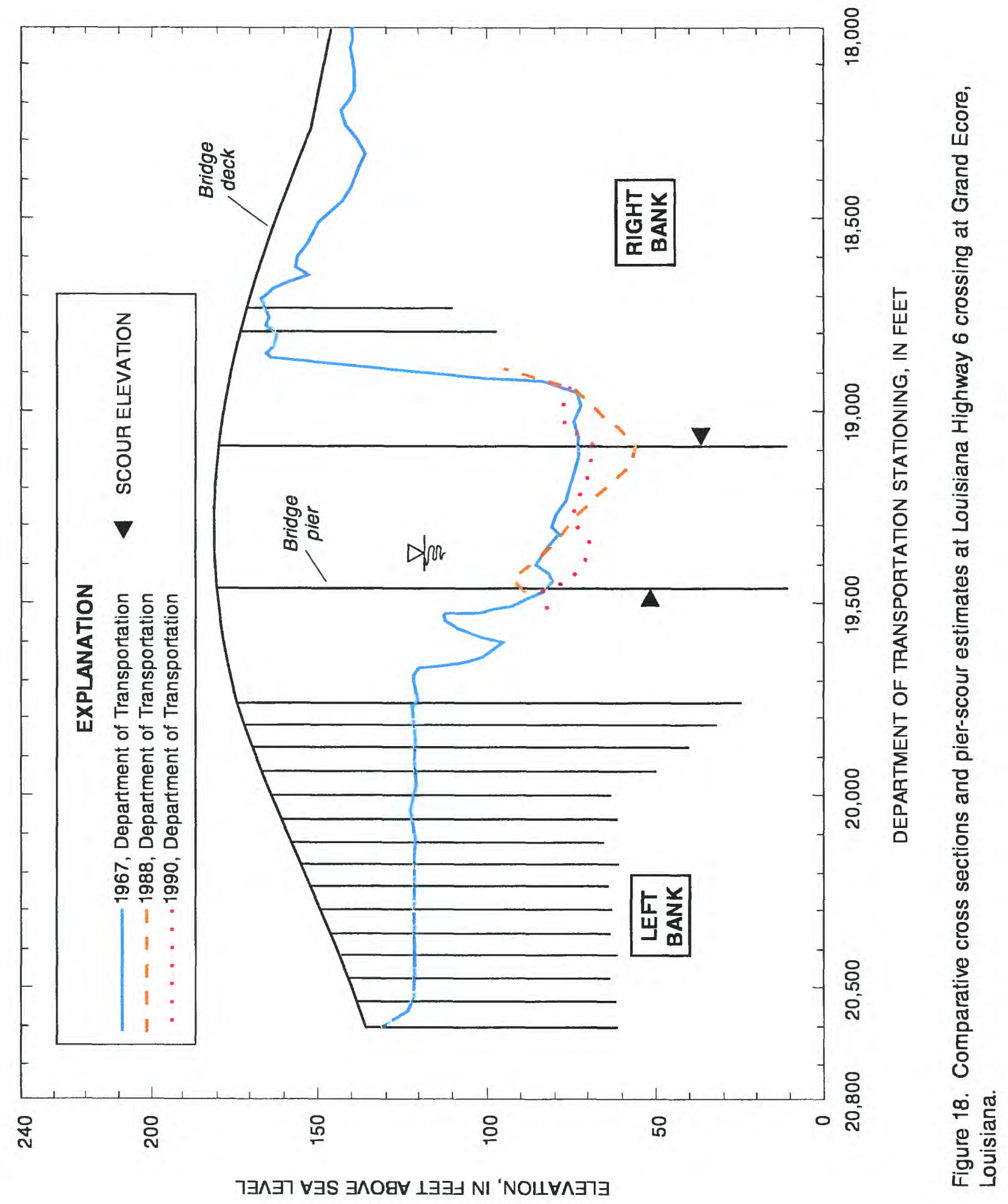




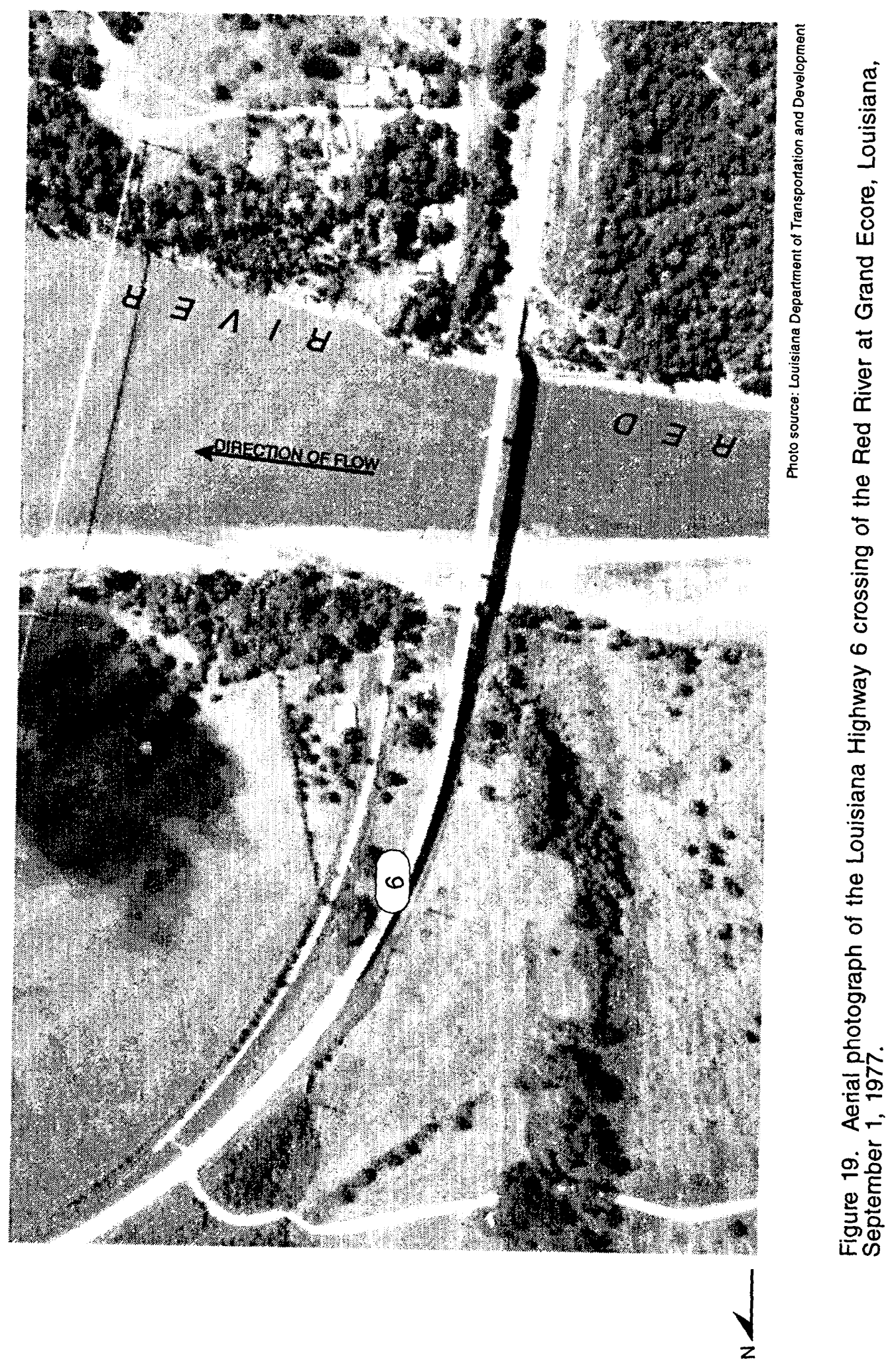




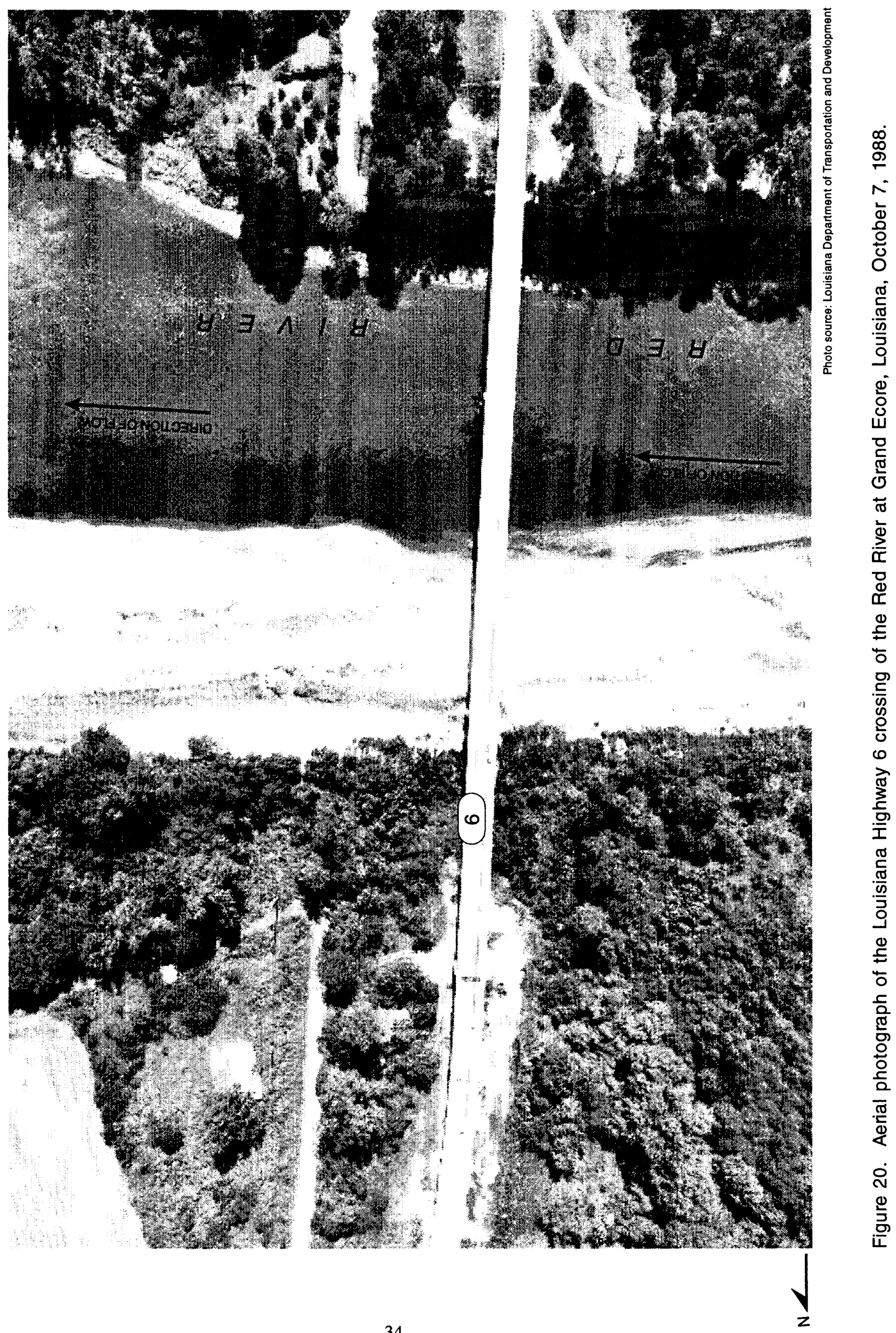




\section{U.S. Highway 84 at Coushatta, Louisiana}

Flood-frequency estimates based on the 500-year flood estimate shown in figure 3 were used for $t$ hydraulic analysis at U.S. Hwy. 84. The 500-year flood estimate is $323,900 \mathrm{ft}^{3} / \mathrm{s}$ (table 1). Hydraulic simulations were calibrated to a historic discharge of about $275,000 \mathrm{ft}^{3} / \mathrm{s}$, which occurred on April 7, 1945, with a water-surface elevation of about $136 \mathrm{ft}$ above sea level. The computed water-surface elevation resulting from hydraulic simulations using the 500-year flood estimate is about $138 \mathrm{ft}$ above sea level (table 7).

The model reach for evaluation of the U.S. Hwy. 84 bridge extends from about $4,000 \mathrm{ft}$ downstream to $500 \mathrm{ft}$ upstream of the highway crossing. The width of the channel at the 500 -year flood estimate ranges from 1,700 to $2,400 \mathrm{ft}$ throughout the reach. The minimum channel-bed elevations for cross sections in the reach ranged from 68 to $98 \mathrm{ft}$ above sea level. The downstream starting elevation for computations using WSPRO was a slope of 0.0004 , which is the same specification used in the calibration simulations. Simulations indicate velocities ranging from 1.9 to $9.5 \mathrm{ft} / \mathrm{s}$ along the cross section at the bridge (table 7).

Table 7. Pier-scour estimates for U.S. Highway 84 crossing the Red River at Coushatta, Louisiana

[DOTD, Louisiana Department of Transportation and Development; WSE, water-surface elevation, in feet above sea level; GrE, ground-surface (channel-bed) elevation, in feet above sea level; $a$, width of pier, in feet; $\mathrm{K}_{1}$, dimensionless correction factor for pier nose shape; $K_{2}$, dimensionless correction factor for angle of flow attack; $K_{3}$, dimensionless correction factor for channel-bed condition; Fr, Froude number computed at the location; $y_{S}$, estimated depth of pier scour, in feet; $y_{1}$, flow de ${ }^{\text {th }}$ directly upstream of the pier, in feet; Tw, estimated top width of the scour hole, in feet; $V$, velocity computed for that locati on in the cross section, in feet per second; $y_{d}$, channel-bed elevation of the computed scour hole, in feet above sea level]

\begin{tabular}{|c|c|c|c|c|c|c|c|c|c|c|c|c|}
\hline $\begin{array}{l}\text { DOTD } \\
\text { station }\end{array}$ & WSE & GSE & $\mathbf{a}$ & $\mathbf{K}_{1}$ & $\mathbf{K}_{2}$ & $\mathbf{K}_{3}$ & $\mathbf{F r}$ & $\mathbf{y}_{\mathrm{S}}$ & $y_{1}$ & Tw & v & $\mathbf{y}_{\mathrm{d}}^{1}$ \\
\hline $127+29$ & 138.0 & 106 & 13 & 1.0 & 1.0 & 1.1 & 0.19 & 19.3 & 32.0 & 53 & 6.2 & 87 \\
\hline $129+57$ & 138.0 & 76 & 13 & 1.0 & 1.0 & 1.1 & .21 & 25.4 & 62.0 & 70 & 9.5 & 51 \\
\hline $132+67$ & 138.0 & 94 & 13 & 1.0 & 1.0 & 1.1 & .21 & 22.5 & 44.0 & 62 & 8.0 & 71 \\
\hline \multicolumn{13}{|c|}{ Right overbank piers } \\
\hline & 138.0 & 100 & 8 & 1.0 & 1.0 & 1.1 & .05 & 8.7 & 38.0 & 24 & 1.9 & 91 \\
\hline & 138.0 & 110 & 8 & 1.0 & 1.0 & 1.1 & .06 & 8.3 & 28.0 & 23 & 1.9 & 102 \\
\hline
\end{tabular}

${ }^{1}$ Numbers are rounded to the nearest foot.

\section{Pier Scour}

For evaluation of pier scour at U.S. Hwy. 84, values for $y_{1}$ at each pier were based on the COE hydrographic survey of 1969 . The cross section represented by this survey represents the lowest channel-bed elevations of the cross sections shown in figure 21 . Values for $\mathrm{K}_{1}=1.0, \mathrm{~K}_{2},=1.0$, and $\mathrm{K}_{3}=1.1$ were based on DOTD bridge plans and recommendations presented by Richardson and others (1993, $\mathrm{p}$. 39-40). The Froude number at the pier location is based upon the value of velocity, which was computed using WSPRO. 


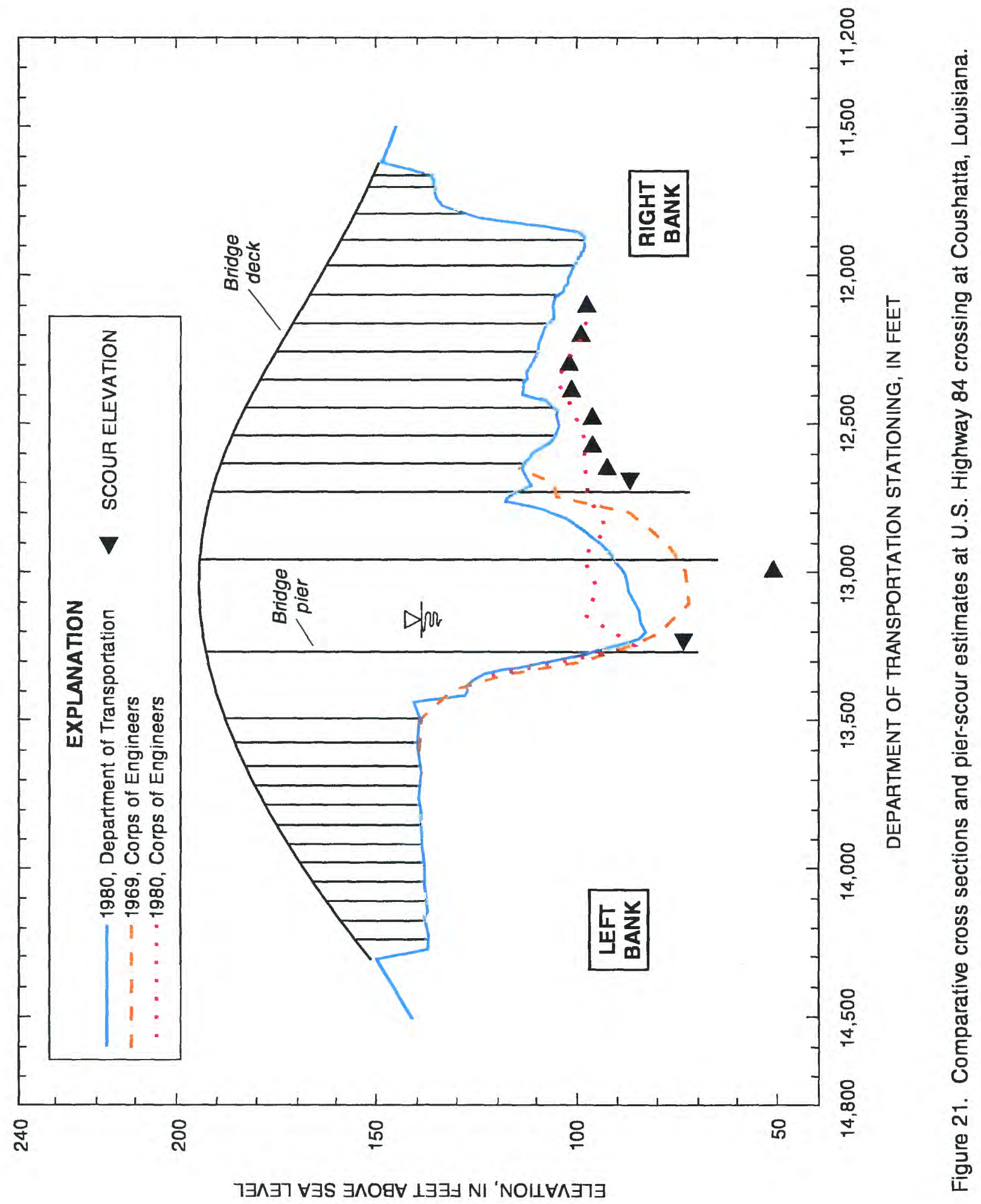


Estimates for scour at the piers on the right overbank were based on a channel-bed elevations between 100 and $110 \mathrm{ft}$ above sea level (table 7). This is the range of elevations for this group of piers based on the 1980 DOTD survey. The scour estimate for the pier at DOTD station $127+29$ is $19.3 \mathrm{ft}$, yielding an elevation for the bed at the scour hole at $87 \mathrm{ft}$ above sea level. The maximum computed scour depth w's $25.4 \mathrm{ft}$ for the pier at DOTD station $129+57$, with an elevation of the bed at the computed scour hole of 51 $\mathrm{ft}$ above sea level. The depth of scour for the pier at DOTD station $132+67$ is approximately $22.5 \mathrm{ft}$, with an estimated channel-bed elevation of $71 \mathrm{ft}$ above sea level.

\section{Channel Stability}

The cross sections at U.S. Hwy. 80 shown in figure 21 indicate several geometric conditions. Tite cross sections from the 1980 surveys by DOTD and COE data differ substantially. This difference is mcst likely due to relatively slight differences in the location where the cross section was surveyed. The DOTD cross section was surveyed exactly at the bridge location. The COE survey cross section is the cross section from the hydrographic survey that was nearest the bridge. The COE cross sections surveyed in 1969 and 1980 differ in longitudinal location on the river by about $500 \mathrm{ft}$. The 1969 cross section was surveyed at river mile 220.6, which is at the highway crossing and the 1980 cross section was surveyed at river mile 220.7. This difference in geometry does not indicate changing bed conditions at the bridge site, but it do:s indicate the difference in channel geometry along a very short reach near the bridge. One condition that shows some stability is the steeply sloping left bank. The location and slope of the left bank is identical for all three surveys shown. Some insight into the variability on the right bank can be emphasized from aerial photographs taken in 1977 and 1987. The photograph taken in 1977 (fig. 22) indicates erosion along the right bank, immediately downstream of the bridge. This evidence of erosion does not appear in the photograph taken in 1987 (fig. 23). This later photograph indicates a shift in flow towards the left bank. Established vegetation can be observed in the 1987 photograph in the areas where bank erosion w's observed in the 1977 photograph. Vegetation also has become established in the areas of deposition on the right bank, upstream of the highway crossing.

\section{Louisiana Highways 511 and 3032, Interstate Highway 20, and U.S. Highway 80 at Shreveport, Louisiana}

Flood-frequency estimates based on the data shown in figure 3 indicate a 500-year flood estimate of $371,300 \mathrm{ft}^{3} / \mathrm{s}$ for highway crossings at Shreveport, La., where the drainage area is $60,614 \mathrm{mi}^{2}$ (table 1). The water-surface elevation associated with this discharge ranges from $171.4 \mathrm{ft}$ above sea level at La. Hwy. 511 to $178.0 \mathrm{ft}$ above sea level at U.S. Hwy. 80 (table 8). Two floods that occurred during the period 1849 through 1990 that are greater than $250,000 \mathrm{ft}^{3} / \mathrm{s}$. The largest discharge recorded during this period was $303,000 \mathrm{ft}^{3} / \mathrm{s}$ in 1945 , with a water-surface elevation of $169.4 \mathrm{ft}$ above sea level.

The model reach for evaluation of the bridges extends from downstream of La. Hwy. 511 to upstream of U.S. Hwy. 80. The width of the channel at the bridges for the 500-year flood estimates range from 4,600 $\mathrm{ft}$ near La. Hwy. 511 to $1,800 \mathrm{ft}$ near U.S. Hwy. 80. The minimum channel-bed elevations for the cross sections at the bridges ranged from 113 to $129 \mathrm{ft}$ above sea level. This minimum elevation is derived from the COE cross sections used for hydraulic routing through the reach. Surveys by DOTD indicate remnants of scour holes near some bridge piers. The channel-bed elevations used for pier scour were taken as the ambient bed level in the vicinity of the pier. The starting downstream boundary condition for computations using WSPRO was a slope of $0.0002 \mathrm{ft} / \mathrm{ft}$. This starting condition produced reasonable flood profiles when calibrating to floods of record. WSPRO simulations indicate an energy gradeline slope of slightly greater than 0.0002 , and velocities ranging from 1.1 to $13.0 \mathrm{ft} / \mathrm{s}$ along the cross sections at the bridges. 


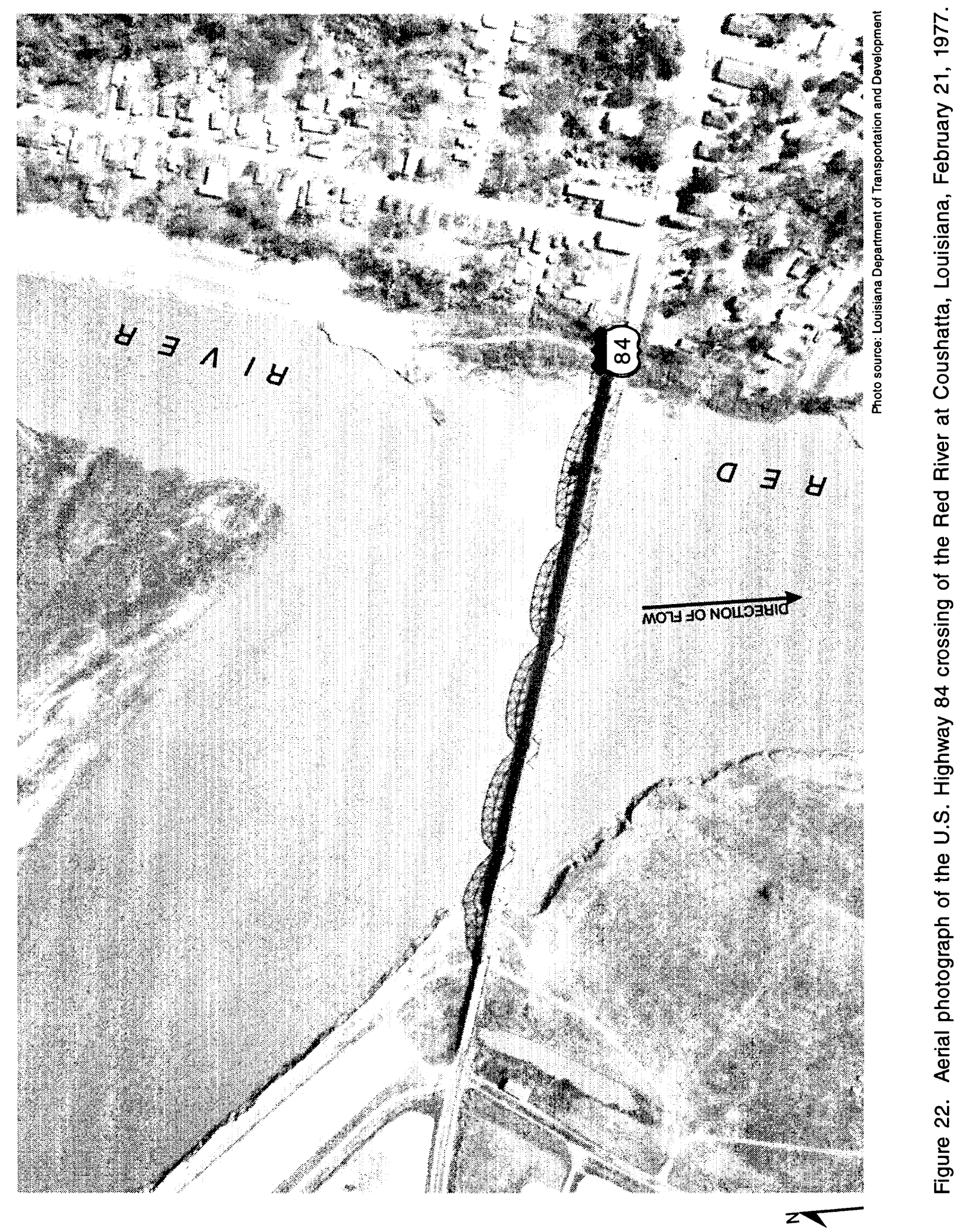




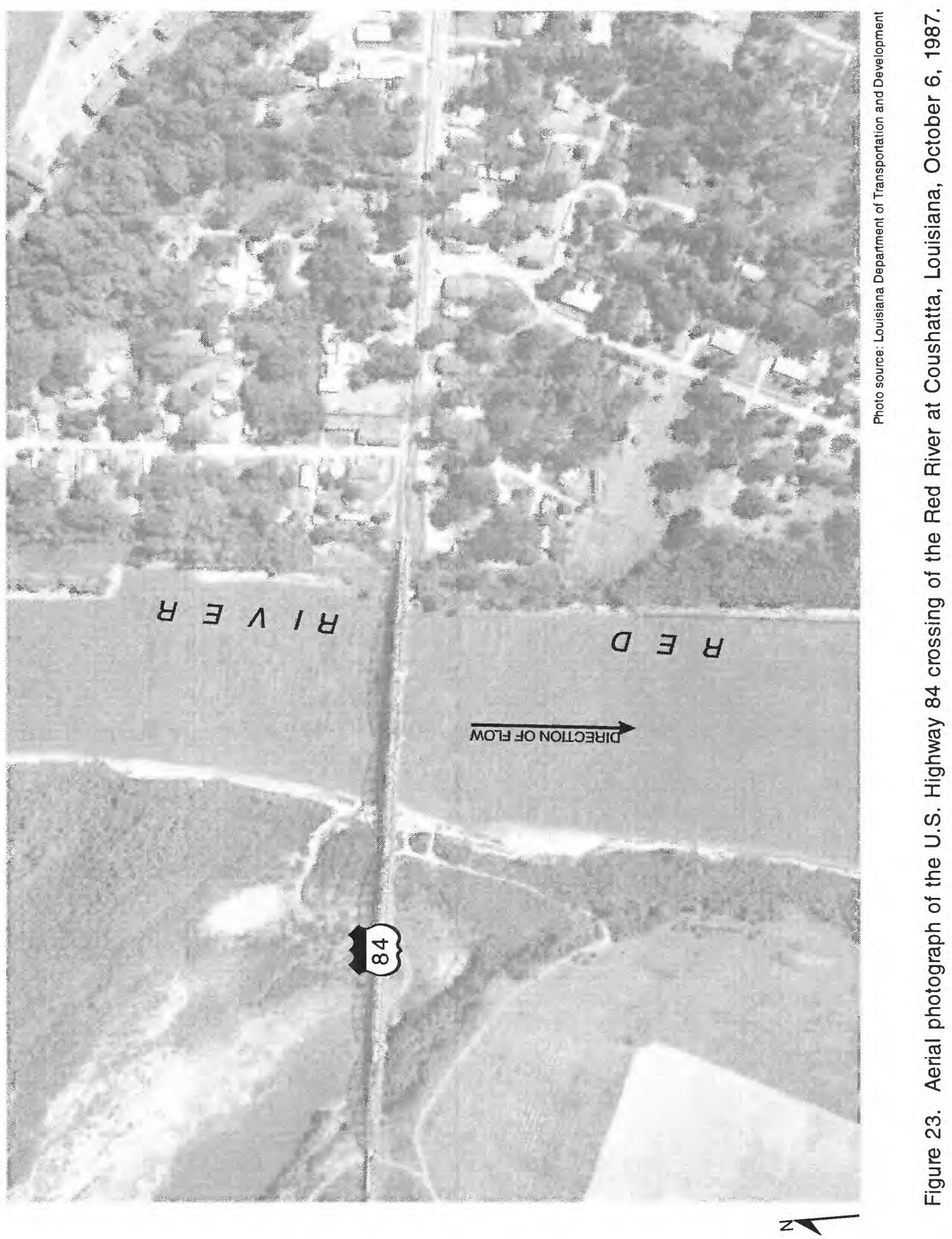


Table 8. Pier-scour estimates for Louisiana Highways 511 and 3032, Interstate Highway 20, and U.S. Highway $8 \mathrm{C}$ crossing the Red River at Shreveport, Louisiana

[DOTD, Louisiana Department of Transportation and Development; WSE, water-surface elevation, in feet above sea level; GSF, ground-surface (channel-bed) elevation, in feet above sea level; a, width of pier, in feet; $\mathrm{K}_{1}$, dimensionless correction factor for pier nose shape; $K_{2}$, dimensionless correction factor for angle of flow attack; $K_{3}$, dimensionless correction factor for channel-bed condition; Fr, Froude number computed at the location; $y_{S}$, estimated depth of pier scour, in feet; $y_{1}$, flow depth directly upstream of the pier, in feet; $\mathrm{Tw}$, estimated top width of the scour hole, in feet; $\mathrm{V}$, velocity computed for that location in the cross section, in feet per second; $y_{d}$, channel-bed elevation of the computed scour hole, in feet above sea level]

\begin{tabular}{|c|c|c|c|c|c|c|c|c|c|c|c|c|}
\hline $\begin{array}{l}\text { DOTD } \\
\text { station }\end{array}$ & WSE & GSE & $\mathbf{a}$ & $\mathbf{K}_{1}$ & $\mathbf{K}_{2}$ & $\mathbf{K}_{3}$ & $\mathrm{Fr}$ & $\mathbf{y}_{\mathrm{S}}$ & $y_{1}$ & $T w$ & $\mathbf{v}$ & $y_{d}^{1}$ \\
\hline \multicolumn{13}{|c|}{ Louisiana Highway 511} \\
\hline $221+50$ & 171.4 & 145 & 10 & 1.0 & 1.0 & 1.1 & 0.04 & 7.8 & 26.4 & 22 & 1.2 & 137 \\
\hline $223+50$ & 171.4 & 139 & 10 & 1.0 & 1.0 & 1.1 & .04 & 8.1 & 32.4 & 22 & 1.2 & 131 \\
\hline $225+50$ & 171.4 & 141 & 10 & 1.0 & 1.0 & 1.1 & .04 & 8.0 & 30.4 & 22 & 1.2 & 133 \\
\hline $227+37$ & 171.4 & 130 & 13 & 1.0 & 1.0 & 1.1 & 19 & 21.1 & 41.4 & 58 & 7.0 & 109 \\
\hline $230+91$ & 171.4 & 130 & 13 & 1.0 & 1.0 & 1.1 & .19 & 21.0 & 41.4 & 58 & 6.9 & 109 \\
\hline $234+93$ & 171.4 & 130 & 13 & 1.0 & 1.0 & 1.1 & .19 & 21.1 & 41.4 & 58 & 7.0 & 109 \\
\hline $238+47$ & 171.4 & 149 & 13 & 1.0 & 1.0 & 1.1 & .05 & 9.4 & 22.4 & 26 & 1.3 & 140 \\
\hline $240+25$ & 171.4 & 150 & 10 & 1.0 & 1.0 & 1.1 & .05 & 7.9 & 21.4 & 22 & 1.3 & 142 \\
\hline $242+80$ & 171.4 & 164 & 10 & 1.0 & 1.0 & 1.1 & .08 & 6.8 & 7.4 & 19 & 1.3 & 157 \\
\hline \multicolumn{13}{|c|}{$\frac{\text { Louisiana Highway } 3032}{\text { (Dual bridges) }}$} \\
\hline $\begin{array}{c}90+61 \text { thru } \\
93+61\end{array}$ & 172.3 & 170 & 4 & 1.0 & 1.0 & 1.1 & .13 & 3.0 & 2.3 & 8 & 1.1 & 167 \\
\hline $94+23$ & 172.3 & 170 & 10 & 1.0 & 1.0 & 1.1 & .13 & 5.4 & 2.3 & 15 & 1.1 & 165 \\
\hline $96+76$ & 172.3 & 147 & 12 & 1.0 & 1.0 & 1.1 & .20 & 17.1 & 25.3 & 47 & 5.7 & 130 \\
\hline $99+79$ & 172.3 & 154 & 12 & 1.0 & 1.0 & 1.1 & .23 & 16.4 & 18.3 & 45 & 5.7 & 138 \\
\hline $103+53$ & 172.3 & 130 & 12 & 1.0 & 1.0 & 1.1 & .31 & 24.9 & 42.3 & 69 & 11.6 & 105 \\
\hline $106+56$ & 172.3 & 124 & 12 & 1.0 & 1.0 & 1.1 & .30 & 25.5 & 48.3 & 70 & 11.7 & 99 \\
\hline $109+09$ & 172.3 & 164 & 10 & 1.0 & 1.0 & 1.1 & .11 & 8.0 & 8.3 & 22 & 1.8 & 156 \\
\hline \multicolumn{13}{|c|}{ Left overbank piers } \\
\hline $\begin{array}{c}109+70 \text { thru } \\
116+31\end{array}$ & 172.3 & 162 & 4 & 1.0 & 1.0 & 1.1 & .10 & 4.5 & 8.3 & 12 & 1.8 & 157 \\
\hline \multicolumn{13}{|c|}{ Interstate Highway 20} \\
\hline $313+25$ & 177.0 & 166 & 5 & 1.0 & 1.0 & 1.1 & .14 & 6.3 & 11.1 & 17 & 2.7 & 160 \\
\hline $314+60$ & 177.0 & 162 & 10 & 1.0 & 1.0 & 1.1 & .12 & 10.3 & 15.0 & 28 & 2.7 & 152 \\
\hline $317+25$ & 177.0 & 129 & 20 & 1.0 & 1.0 & 1.1 & .28 & 34.7 & 48.0 & 95 & 11.1 & 94 \\
\hline $320+85$ & 177.0 & 120 & 20 & 1.0 & 1.0 & 1.1 & .30 & 38.0 & 57.0 & 105 & 13.0 & 82 \\
\hline $323+60$ & 177.0 & 164 & 10 & 1.0 & 1.0 & 1.1 & .14 & 10.3 & 13.0 & 28 & 2.8 & 154 \\
\hline $324+80$ & 177.0 & 165 & 5 & 1.0 & 1.0 & 1.1 & .14 & 6.5 & 12.0 & 18 & 2.8 & 159 \\
\hline $326+00$ & 177.0 & 164 & 5 & 1.0 & 1.0 & 1.1 & .14 & 6.5 & 13.0 & 18 & 2.8 & 157 \\
\hline \multicolumn{13}{|c|}{ U.S. Highway 80} \\
\hline $\begin{array}{l}13+50 \text { and } \\
14+50\end{array}$ & 178.0 & 172 & 5 & 1.0 & 1.0 & 1.1 & .17 & 5.5 & 6.0 & 15 & 2.4 & 166 \\
\hline $15+60$ & 178.0 & 172 & 10 & 1.0 & 1.0 & 1.1 & .17 & 8.6 & 6.0 & 24 & 2.4 & 163 \\
\hline $17+40$ & 178.0 & 134 & 15 & 1.0 & 1.0 & 1.1 & .31 & 29.2 & 44.0 & 80 & 11.8 & 105 \\
\hline $22+60$ & 178.0 & 131 & 15 & 1.0 & 1.0 & 1.1 & .33 & 30.6 & 47.0 & 84 & 12.9 & 100 \\
\hline $24+40$ & 178.0 & 164 & 10 & 1.0 & 1.0 & 1.1 & .12 & 10.0 & 14.0 & 28 & 2.6 & 154 \\
\hline $\begin{array}{c}25+50 \text { and } \\
26+50\end{array}$ & 178.0 & 171 & 5 & 1.0 & 1.0 & 1.1 & .17 & 5.8 & 7.0 & 16 & 2.6 & 165 \\
\hline
\end{tabular}

${ }^{1}$ Numbers are rounded to the nearest foot. 


\section{Louisiana Highway 511 at Shreveport, Louisiana}

\section{Pier Scour}

For evaluation of pier scour at La. Hwy. 511, values for $y_{1}$ at each pier were based on the DOTD hydrographic survey of 1990 . The cross section represents the general channel geometry at the bridge. Surveys performed around the bridge structure in 1988 and 1990 show remnants of scour at the bridge piers as shown in figure 24. Values for $\mathrm{K}_{1}=1.0, \mathrm{~K}_{2}=1.0$, and $\mathrm{K}_{3}=1.1$ were based on DOTD bridge plans and recommendations presented by Richardson and others (1993). The Froude number at the pier location is based upon the value of velocity, which was computed using WSPRO. The right overbank piers at DOTD stations $221+50$ and $223+50$ had computed scour depths of approximately 7.8 and $8.1 \mathrm{ft}$ (table 8 ). The maximum computed scour depth was approximately $21.1 \mathrm{ft}$ at the main piers, at DOTD stations $227+37$, $230+91$, and 234+93 with a channel-bed elevation of the computed scour hole of about $109 \mathrm{ft}$ above sea level. The left overbank piers at DOTD stations $238+47,240+25$, and $242+80$ have computed scour deptrs between 6.8 and $9.4 \mathrm{ft}$.

\section{Channel Stability}

In evaluation of channel stability at La. Hwy. 511, the hydrographic surveys of 1965, 1969, 1988, an 1 1990 show considerable dynamic activity of the channel bed near DOTD stations 227+37 and 230+91 (fig. 24). The 1965 and the 1969 cross sections have little resemblance to each other within these station limit: The 1969 and 1988 cross sections show about the same channel-bed elevation at DOTD stations 227+37 and 234+93, but indicate a decrease in the channel-bed elevation at DOTD station 230+91. The reach cf the river is generally straight for two to three channel widths upstream of the bridge (figs. 25 and 26), and some of the bed activity may be from the changing of the "flow crossings" for different ranges of flow. The 1988 survey indicates remnants of scour around the main piers. The 1990 survey indicates a deepening of the observed residual pier scour.

\section{Louisiana Highway 3032 at Shreveport, Louisiana}

\section{Pier Scour}

For analysis of pier scour at La. Hwy. 3032, values for $y_{1}$ at each pier were based on the DOTD hydrographic survey of 1990. The cross section resembles the DOTD section of 1988 and shows deepene-1 scour hole remnants (fig. 27). The right overbank piers between DOTD stations $90+61$ and $93+61$ have an estimated scour depth of $3.0 \mathrm{ft}$. The main piers at DOTD stations $94+23,96+76$, and $99+79$ have predicted scour depths ranging from 5.4 to $16.4 \mathrm{ft}$ (fig. 27, table 8). The largest scour depths of 24.9 and $25.5 \mathrm{ft}$ occurred at piers at DOTD stations $103+53$ and $106+56$. These scour depths resulted in the minimum elevations of 105 and $99 \mathrm{ft}$ above sea level. Pier scour computations at DOTD station 106+56 indicate that the pile cap was exposed. The left overbank pier at DOTD station 109+09 had a computed scour depth cf approximately $8.0 \mathrm{ft}$, resulting in a channel-bed elevation of $156 \mathrm{ft}$ above sea level. The remaining left overbank piers have scour estimates of approximately $4 \mathrm{ft}$. 


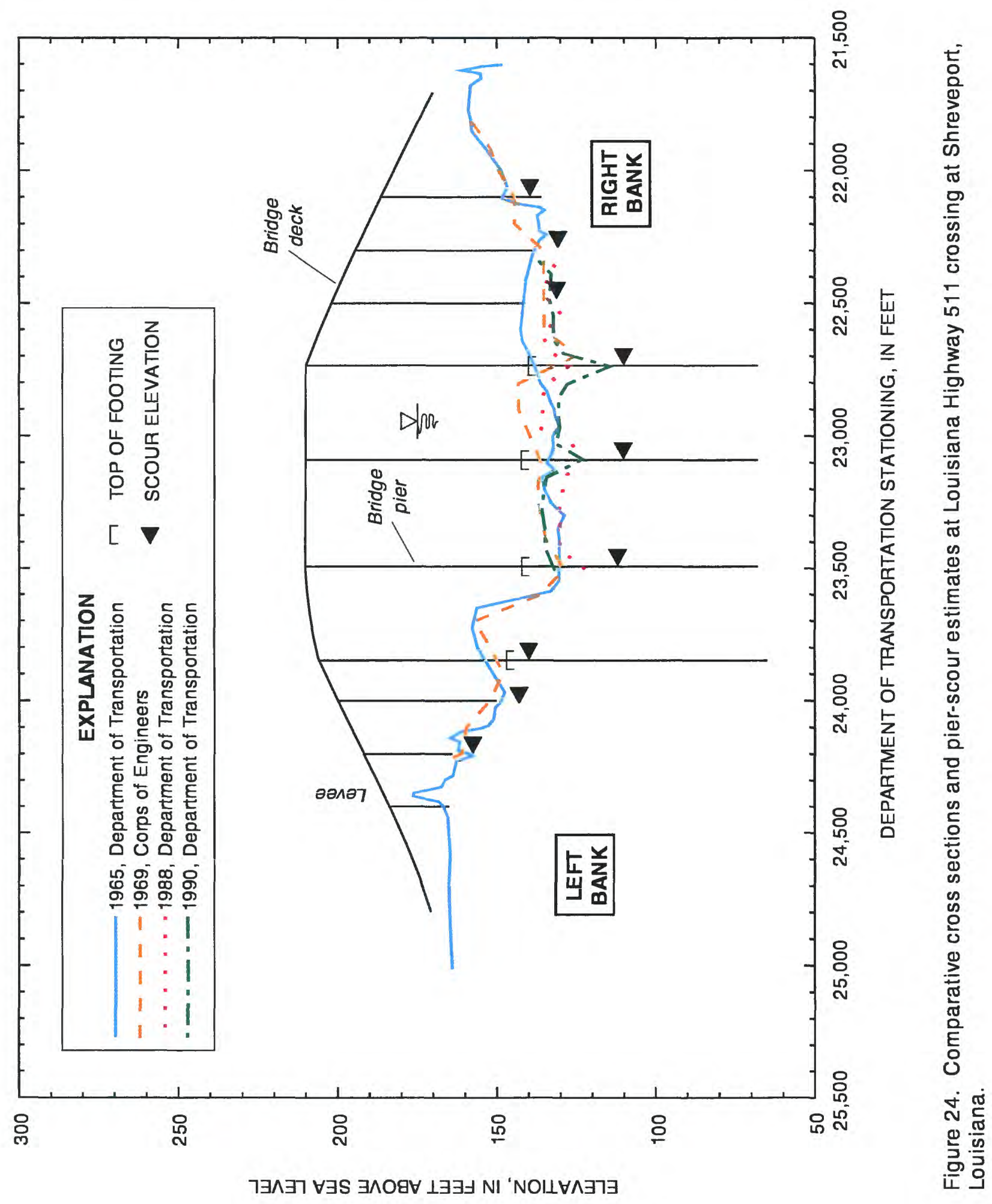




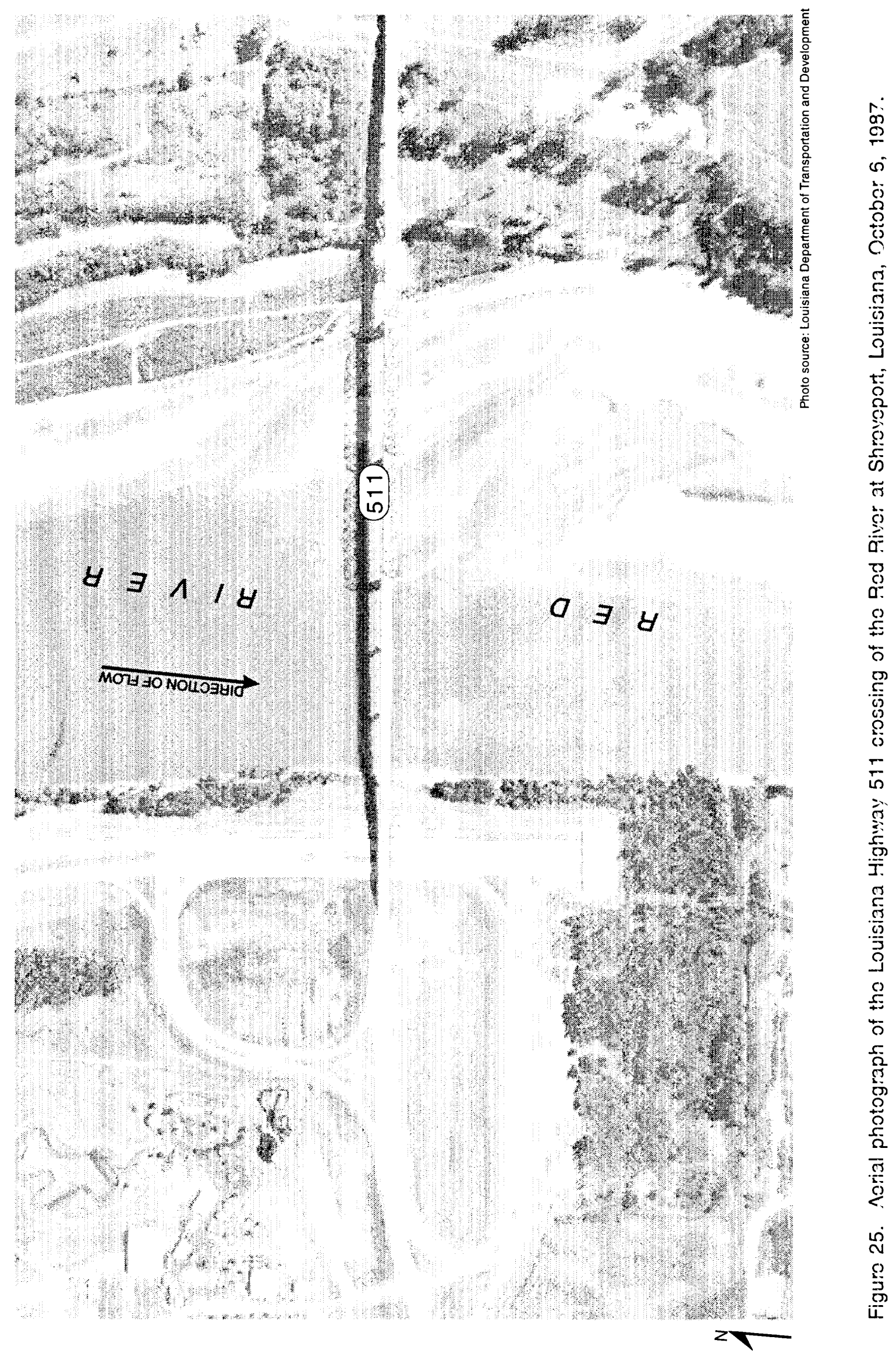




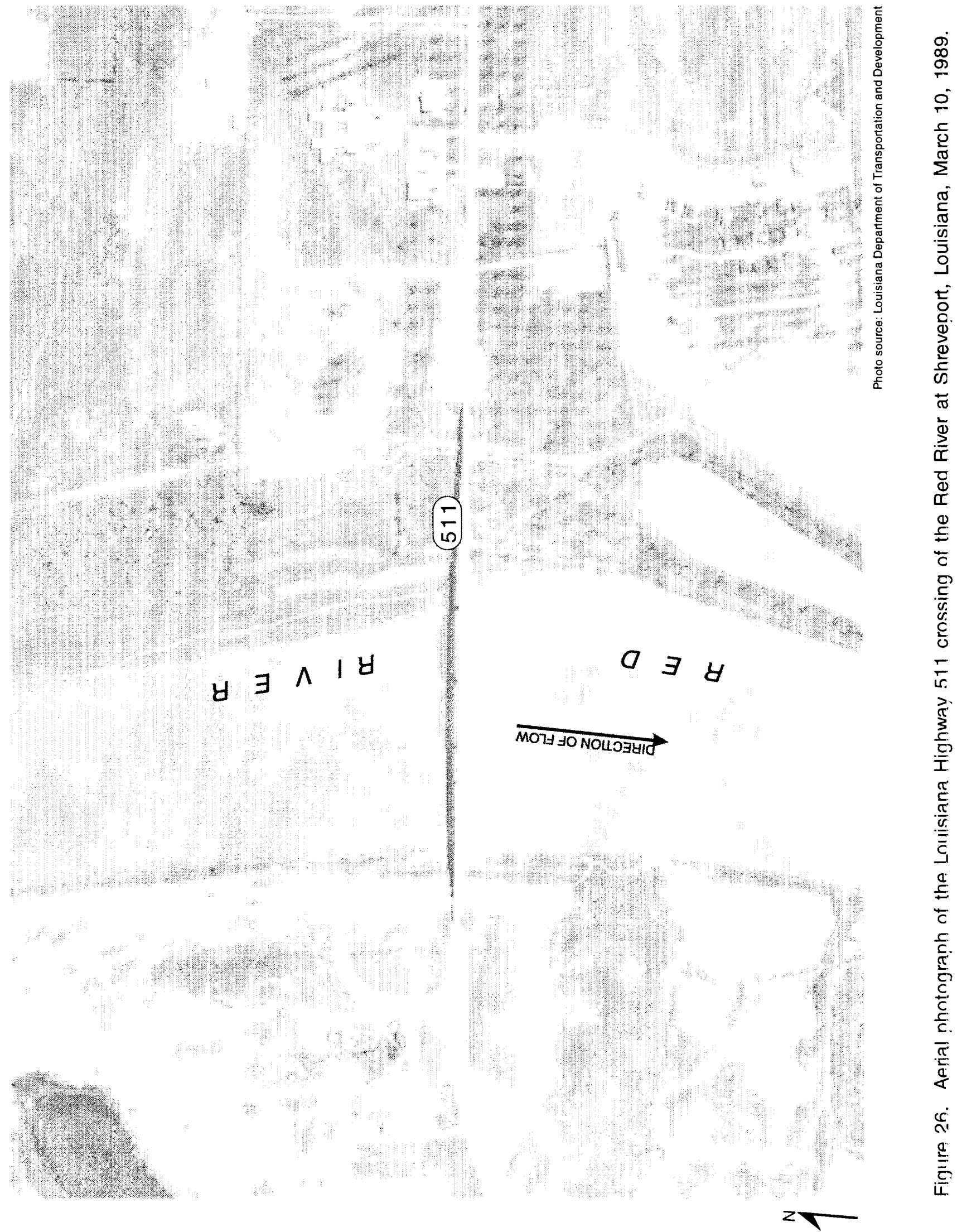




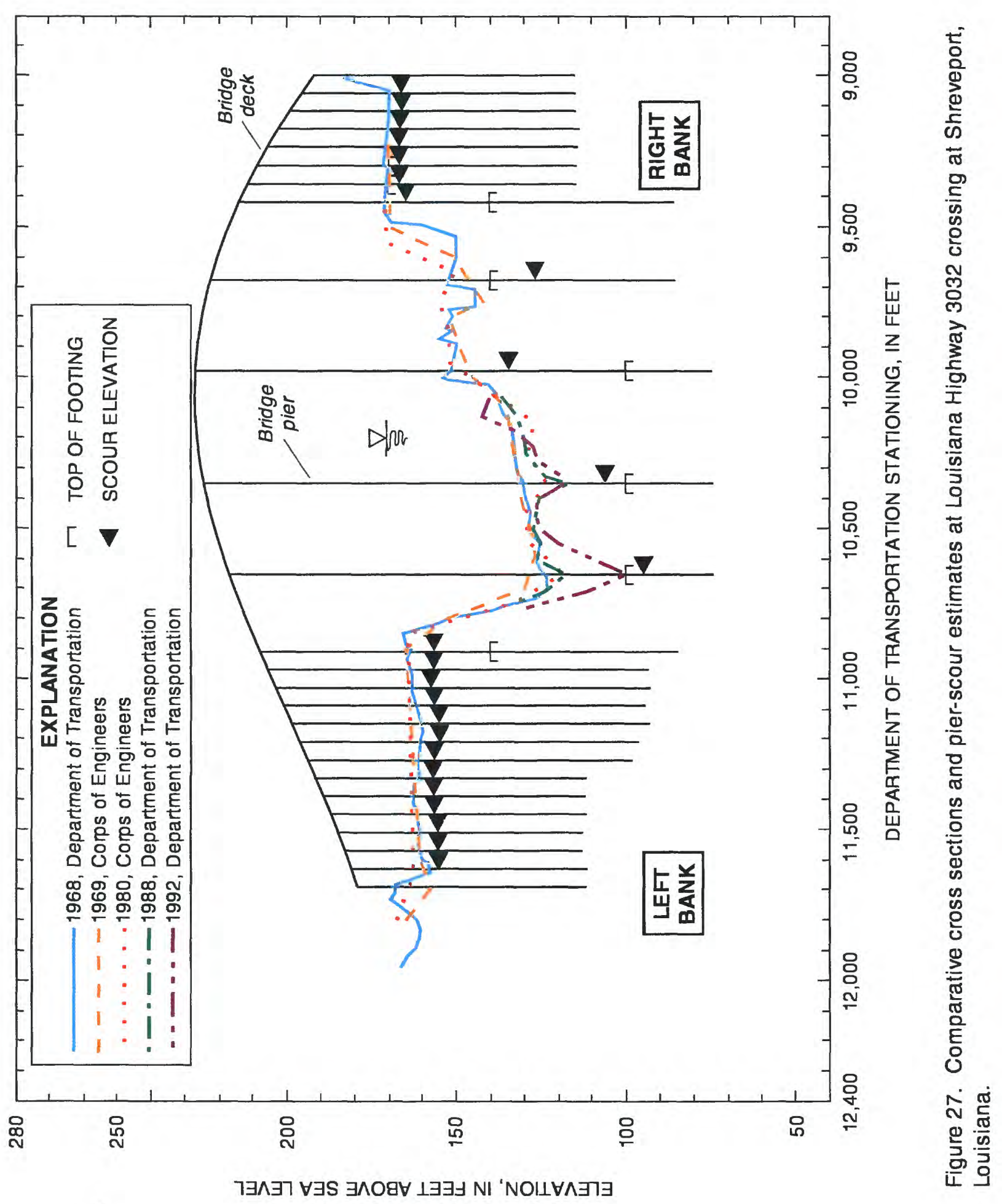


The La. Hwy. 3032 bridge crossing the Red River near Shreveport is a part of the USGS National Bridge Scour Program. Part of the mission of the program is collection of scour data. Data were recently collected during a flood at this site on May 19 and 22, 1990, which had a peak discharge of approximatel:" $297,000 \mathrm{ft}^{3} / \mathrm{s}$. Measurements of velocity and depth at the approach to the pier and measurements of the be 1 around the pier were obtained. The depth of the scour around the pier at DOTD station 106+56 ranged from 17 to $25 \mathrm{ft}$, with an accuracy of 1 to $2 \mathrm{ft}$. The estimated value (table 8 ) is $25.5 \mathrm{ft}$, which is within the range of the observed values. This comparison of observed scour at a discharge that is about 80 percent of the discharge used in computing the estimate provides greater confidence in the estimated values.

\section{Channel Stability}

Hydrographic surveys of 1968 and 1969 indicate no substantial changes in the channel in the vicinit:" of the bridge. The DOTD cross sections of 1988 and 1992 taken at the bridge indicate remnants of pier scour at DOTD stations 103+53 and 106+56. The 1988 and 1992 surveys indicate that the lowest channel-bed elevations are on the left bank. Although the channel is straight for three or four channel widths upstream and downstream (figs. 28 and 29), this straight part of the reach is between two relatively long and mild curves to the right. The general shape of the section defined by these two cross sections is typical of a reach which is turning to the right. The bed elevation at the pier (DOTD station 106+56) from the 1992 survey is more than $25 \mathrm{ft}$ deeper than the elevation indicated by the surveys of 1968 and 1969. Remediation and protective measures could be considered if the deepening trend continues.

\section{Interstate Highway 20 at Shreveport, Louisiana}

\section{Pier Scour}

For evaluation of pier scour at Interstate Hwy. 20, values for $y_{1}$ at each pier were based on the COE hydrographic survey of 1980 . The cross section resembles the channel-bed elevations recorded in 1953 and 1969 , but is the highest of the three cross sections shown in figure 30 . The right overbank pier has an estimated scour depth of $6.3 \mathrm{ft}$, which corresponds to a bed elevation of $160 \mathrm{ft}$ above sea level (table 8). This elevation is equal to the pile-footing cap elevation. The pier at DOTD station $314+60$ has an estimated scour depth of $10.3 \mathrm{ft}$, which corresponds to a bed elevation of $152 \mathrm{ft}$ above sea level. This elevation is well above the pile-footing cap. The main piers at DOTD stations $317+25$ and $320+85$ have the largest predicted scour depths of approximately 34.7 and $38.0 \mathrm{ft}$. The minimum predicted channel-bed elevation from pier scour is $82 \mathrm{ft}$ above sea level for the pier at DOTD station $320+85$. Pier-scour computations for left overbank piers at DOTD stations $323+60,324+80$, and $326+00$ have estimated scour depths of $10.3,6.5$, and $6.5 \mathrm{f}$.. The scour estimate at DOTD station $326+00$ indicates that the pile cap is slightly exposed. Computations outlined by Richardson and others $(1991,1993)$ for exposed footings were used to evaluate the scour potential for the exposed pile cap. The resulting scour depth was not substantially different from the initial pier scour computation. 

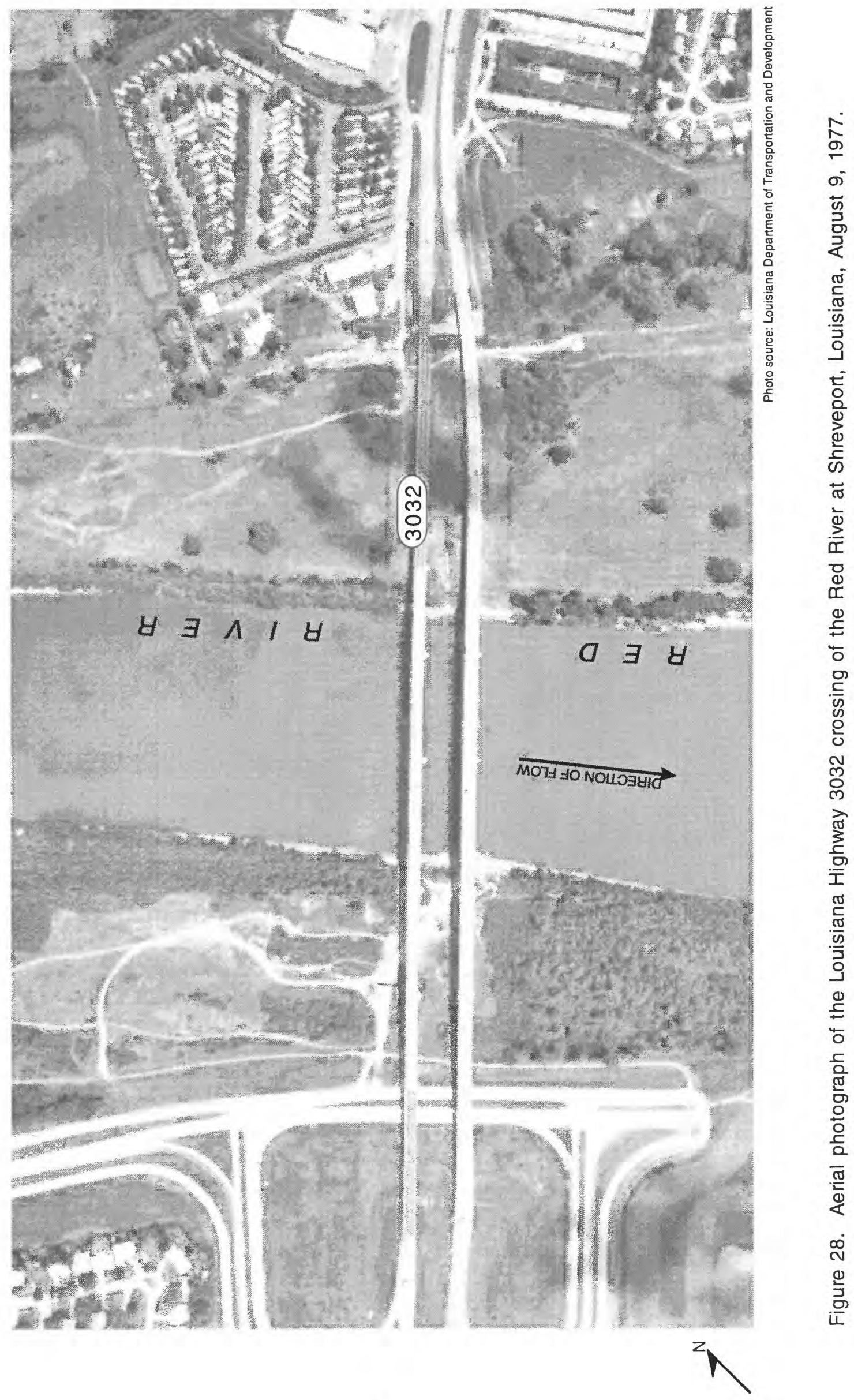


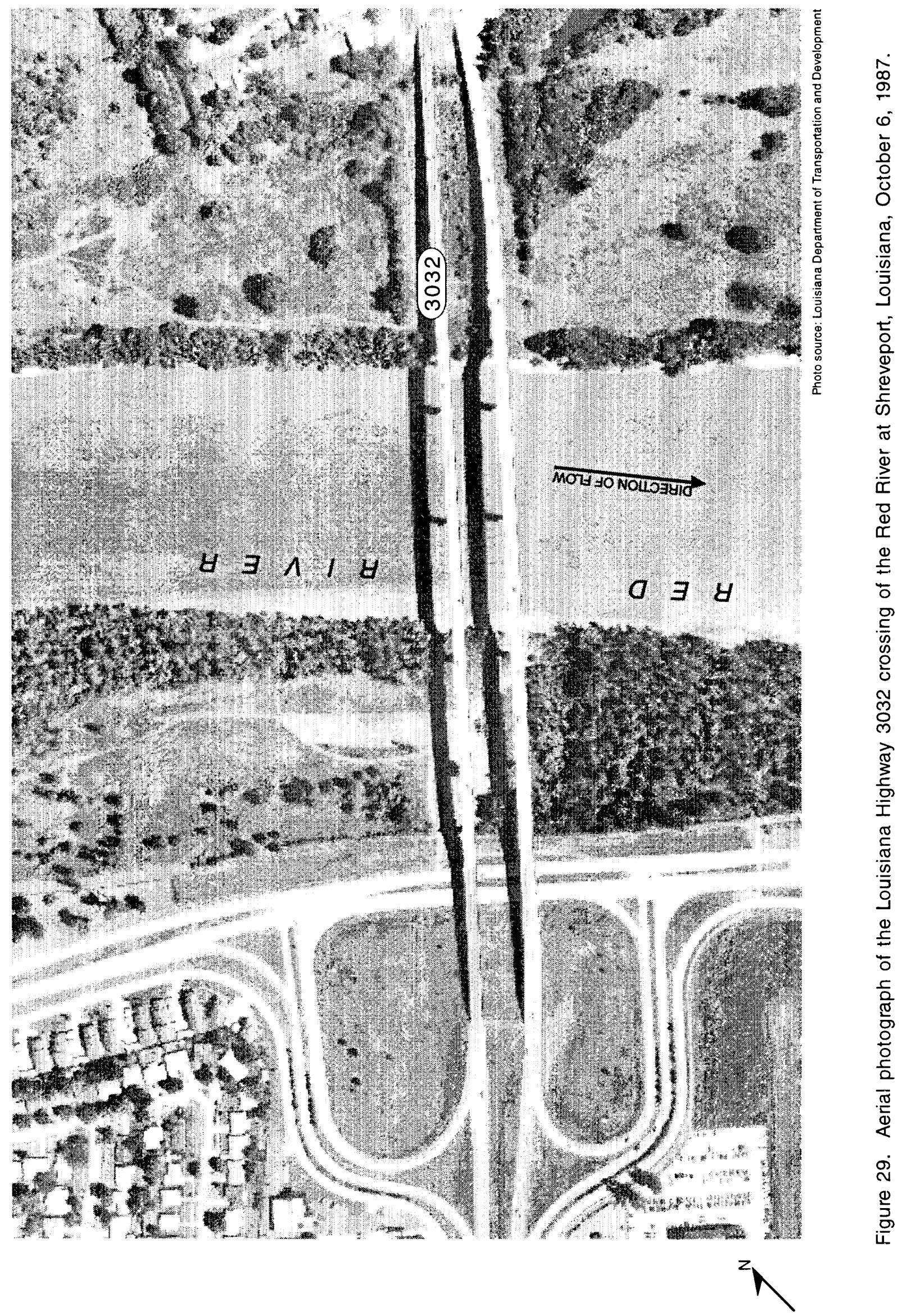




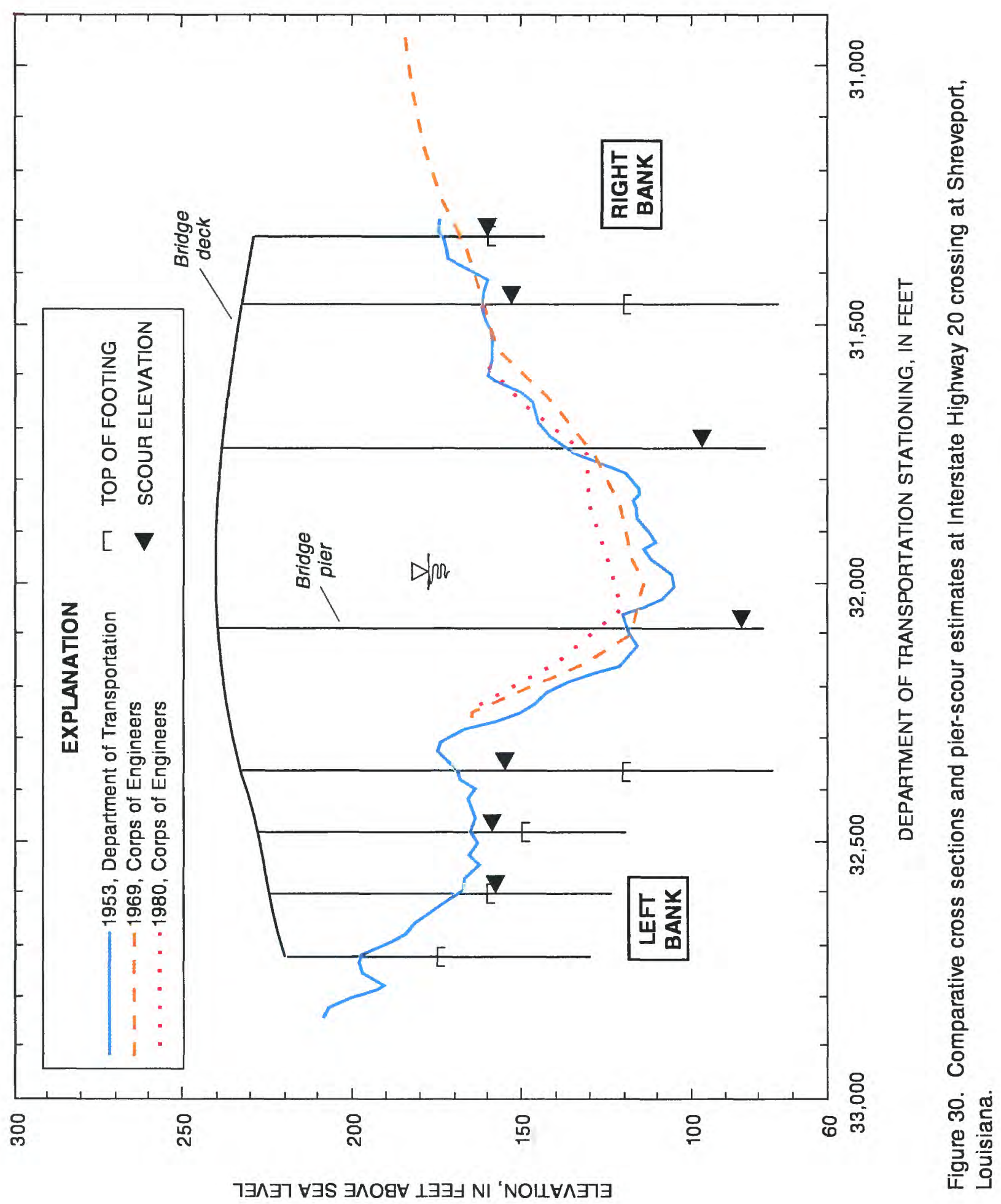




\section{Channel Stability}

In evaluation of channel stability of Interstate Hwy. 20, the three surveys shown in figure 30 indicate that the cross section is fairly uniform. The channel is straight for four channel widths upstream (figs. 31 and 32), and the channel begins a turn to the left at the bridge. The cross sections shown indicate a gradual increase in channel-bed elevations. Although the cross sections seem to indicate a trend, these cross sections were taken over a 23-year period and may only be three "snapshots" of seasonal variations in the channel bed. Also to be considered is that the cross sections from the various hydrographic surveys were not taken in exactly the same location, but are simply those cross sections that are closest to the highway crossing. It would not be unlikely for the general shape to be the same, while the minimum channel-bed elevations change by 6 to $8 \mathrm{ft}$ longitudinally between cross-section locations.

\section{U.S. Highway 80 at Shreveport, Louisiana}

\section{Pier Scour}

For evaluation of pier scour at U.S. Hwy. 80, values for $y_{1}$ at each pier were based on the DOTD hydrographic survey of 1992. This cross section closely approximates the two previous surveys of 1969 and 1980 (fig. 33). Right bank piers at DOTD stations $13+50$ and $14+50$ have scour estimates of $5.5 \mathrm{f}^{*}$, which corresponds to a channel-bed elevation of $166 \mathrm{ft}$ above sea level (table 8). The overbank pier $a t$ DOTD station $15+60$ has an estimated scour depth of $8.6 \mathrm{ft}$, resulting in a bed elevation of $163 \mathrm{ft}$ above sea level. The deepest scour estimates are at the main-channel piers at DOTD stations $17+40$ and $22+60$. These two locations have scour-depth estimates of 29.2 and $30.6 \mathrm{ft}$, respectively, resulting in channel-bef elevations of 105 and $100 \mathrm{ft}$ above sea level. These computations indicate that the pile-footing caps becom? exposed. The pier at DOTD station $22+60$ had the greatest initial depth and greatest velocity of all pier locations at the bridge. The left overbank piers at DOTD stations $24+40,25+50$, and $26+50$ have estimate scour depths of 10.0, 5.8, and $5.8 \mathrm{ft}$.

\section{Channel Stability}

In evaluation of channel stability at U.S. Hwy. 80, the channel geometry as indicated by the three most recent surveys over a 23-year period show that the channel is relatively stable at this location. The cross sections represented by surveys of 1931 and 1932 indicate channel-bed elevations that are $10 \mathrm{ft}$ lower at the lowest points. This indicates a rise in the channel-bed elevation during the first 37 -year period covere 1 by the surveys shown, then a relatively stable geometry for the next 23 years. This activity could bo attributed to a number of structural changes on the river over the time span covered in the cross sections indicated. Assuming that the most recent group of cross sections are the most important and the most representative, the channel at the bridge crossing appears to be stable. Aerial photographs taken in 1977 and 1988 (figs. 34 and 35), indicate a straight reach for several widths upstream and downstream of the. highway. 


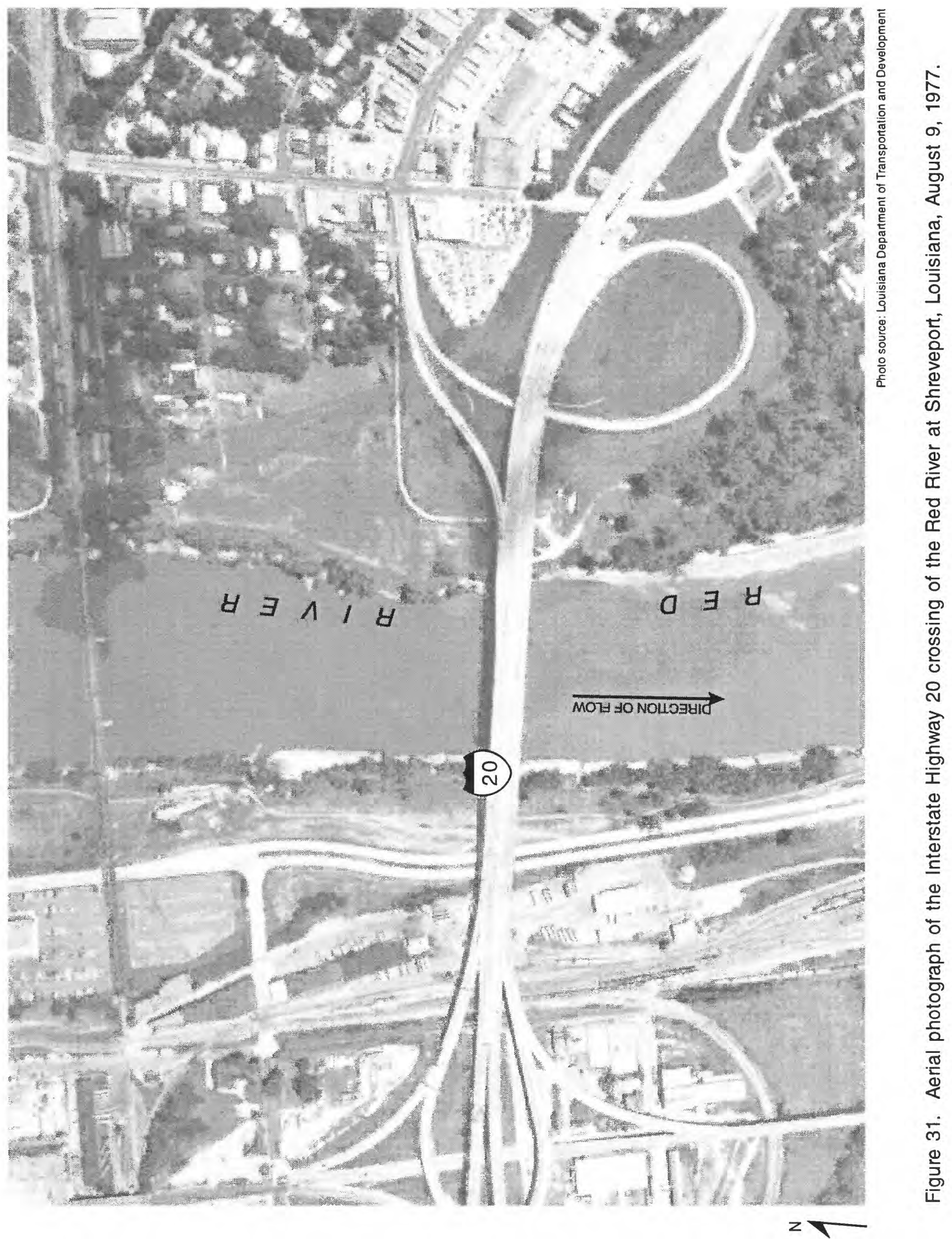




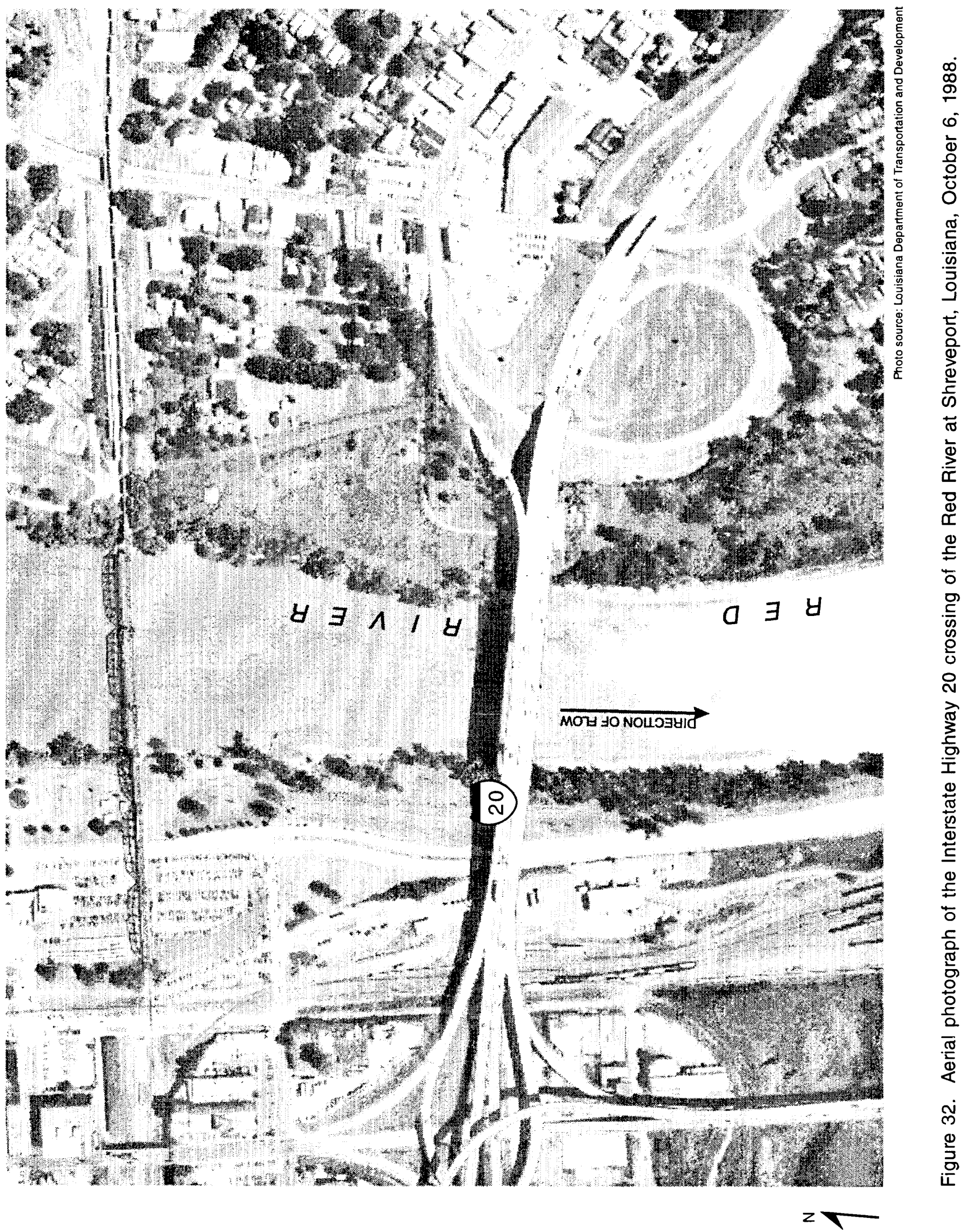




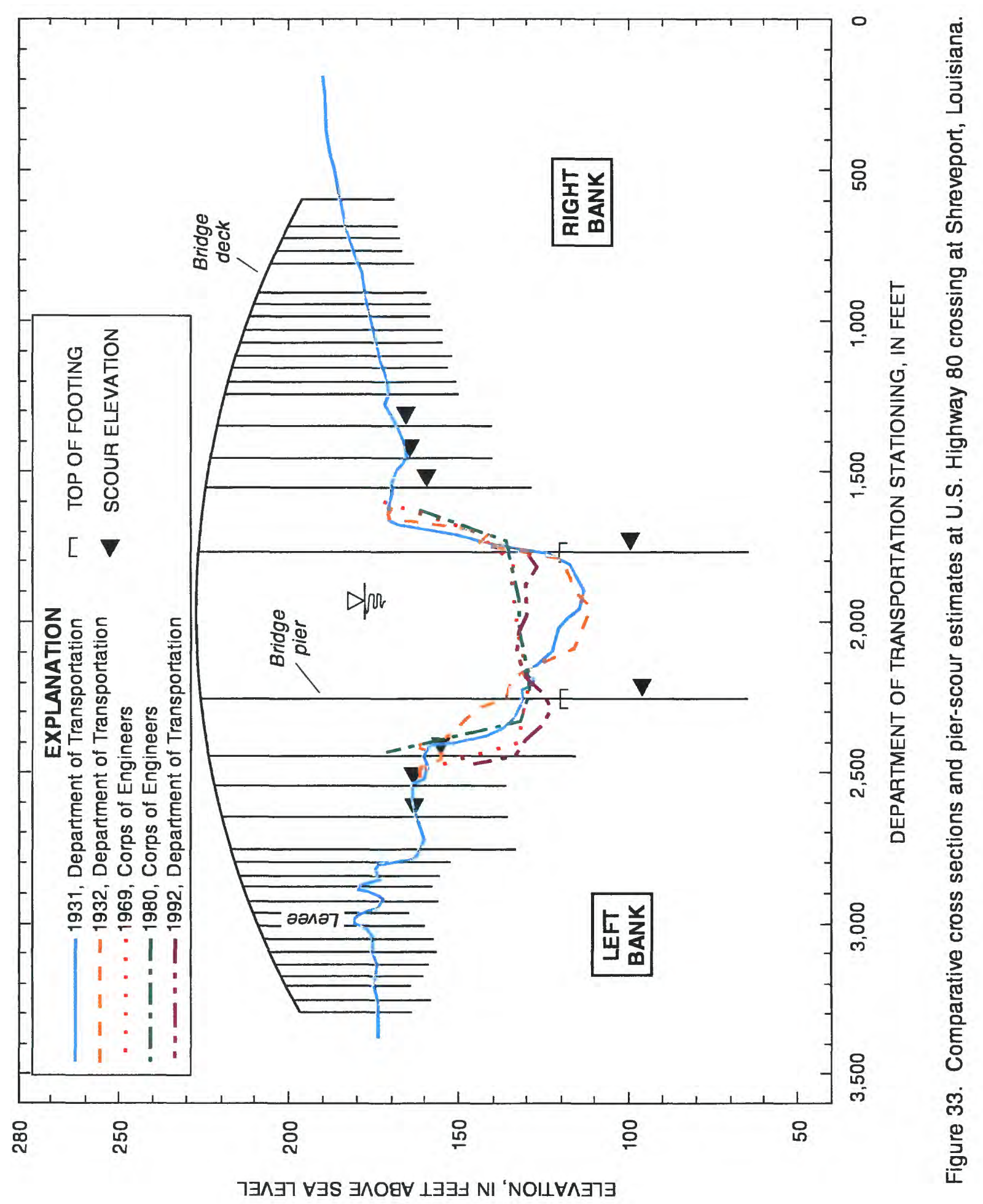




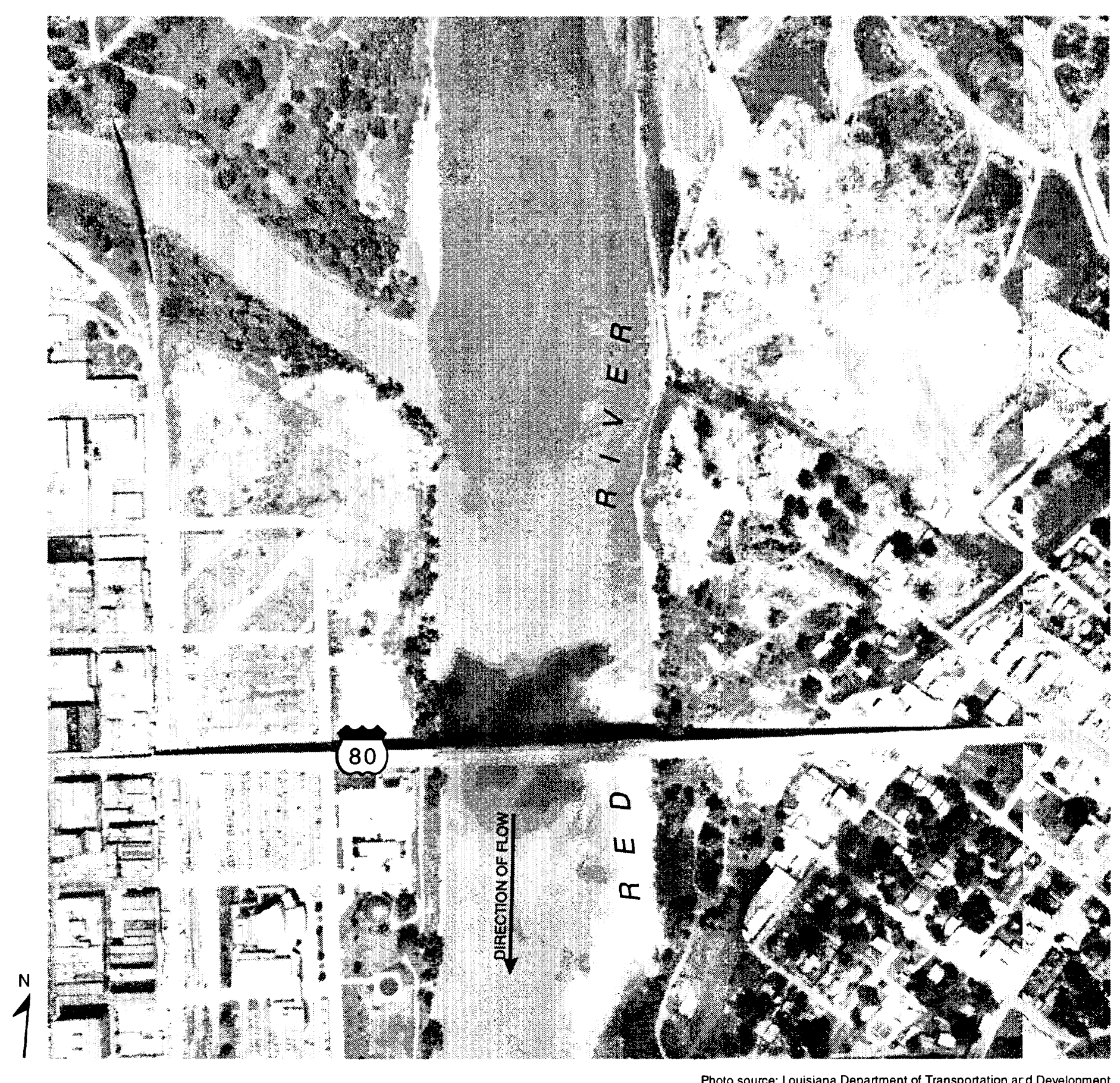

Figure 34. Aerial photograph of the U.S. Highway 80 crossing of the Red River at Shreveport, Louisiana, August 9, 1977. 


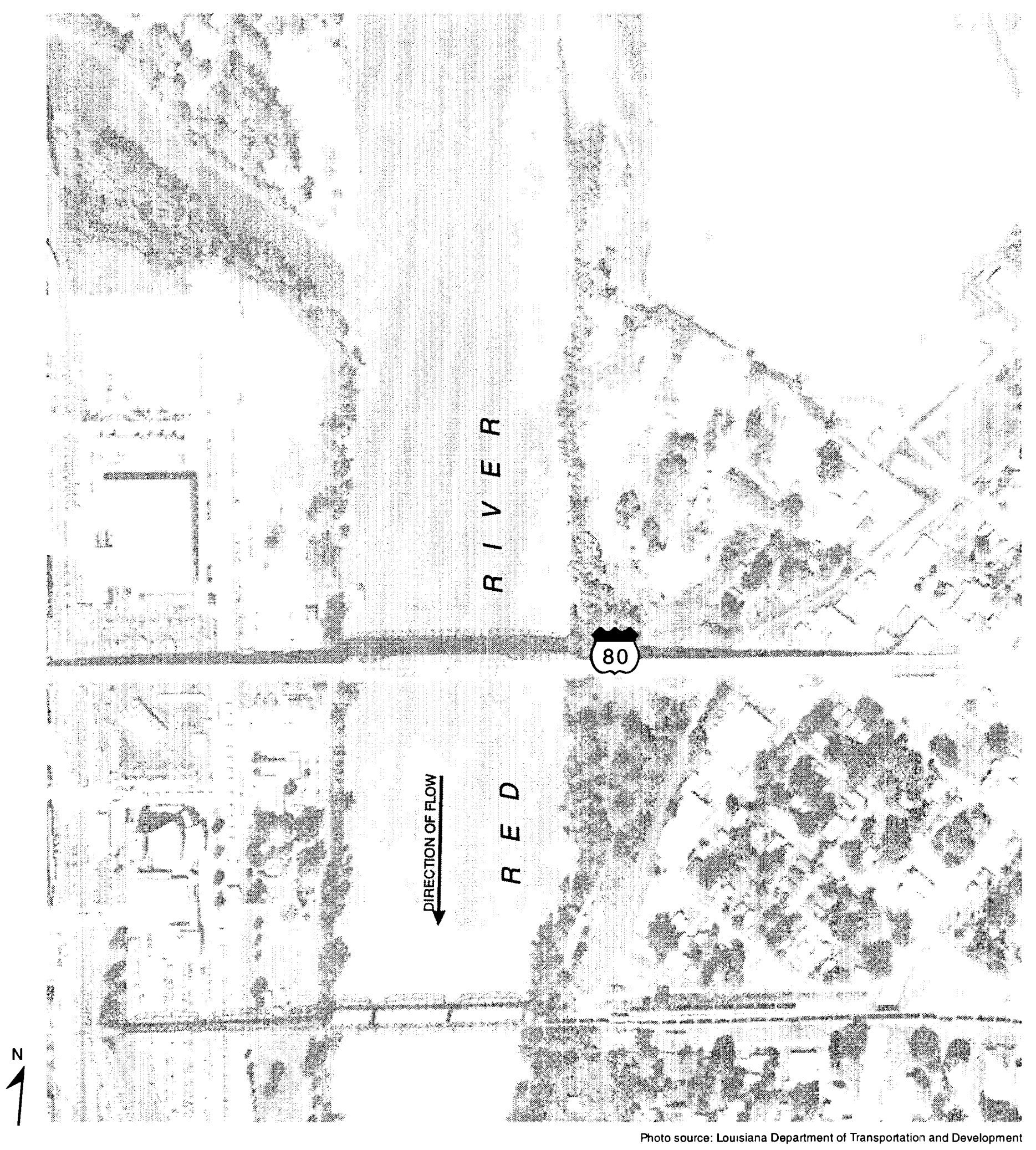

Figure 35. Aerial photograph of the U.S. Highway 80 crossing of the Red River at Shreveport, Louisiana, October 6, 1987. 


\section{Interstate Highway 220 at Shreveport, Louisiana}

Flood-frequency estimates based on the data shown in figure 3 were used for the hydraulic analysis. The 500-year flood estimate is $371,300 \mathrm{ft}^{3} / \mathrm{s}$ (table 1). Hydraulic computations were based on calibration simulations for other highway crossings at Shreveport. The model reach for evaluation of the Interstate Hwy. 220 bridge extends from about 6,500 ft downstream of the highway crossing through the bridge cross section. The width of the channel at the 500-year flood estimate ranges from 3,000 to 5,500 $\mathrm{ft}$ throughout the reach. The minimum channel-bed elevations for cross sections in the reach ranged from 129 to $137 \mathrm{ft}$ above sea level. The starting downstream boundary condition for computations using WSPRO w'as a slope of 0.0002 , which is the same slope used in the calibration simulations. The computed water-surface elevation resulting from hydraulic simulations using the 500 -year flood estimate was about $178.7 \mathrm{ft}$ abc ve sea level (table 9). Simulations indicate velocities ranging from 3.1 to $8.6 \mathrm{ft} / \mathrm{s}$ along the cross section at the bridge.

Table 9. Pier-scour estimates for Interstate Highway 220 crossing the Red River near Shreveport, Louisiana

[DOTD, Louisiana Department of Transportation and Development; WSE, water-surface elevation, in feet above sea level; GSE, ground-surface (channel-bed) elevation, in feet above sea level; a, width of pier, in feet; $\mathrm{K}_{1}$, dimensionless correction factor for pier nose shape; $K_{2}$, dimensionless correction factor for angle of flow attack; $K_{3}$, dimensionless correction factor for channel-bed condition; Fr, Froude number computed at the location; $y_{S}$, estimated depth of pier scour, in feet; $y_{1}$, flow depth directly upstream of the pier, in feet; Tw, estimated top width of the scour hole, in feet; $\mathrm{V}$, velocity computed for that location in the cross section, in feet per second; $y_{d}$, channel-bed elevation of the computed scour hole, in feet above sea level]

\begin{tabular}{ccccccccccccc}
\hline $\begin{array}{c}\text { DOTD } \\
\text { station }\end{array}$ & WSE & GSE & $\mathbf{a}$ & $\mathbf{K}_{\mathbf{1}}$ & $\mathbf{K}_{2}$ & $\mathbf{K}_{\mathbf{3}}$ & \multicolumn{1}{c}{ Fr } & $\mathbf{y}_{\mathbf{S}}$ & $\mathbf{y}_{\mathbf{1}}$ & $\mathbf{T w}$ & $\mathbf{V}$ & $\mathbf{y}_{\mathrm{d}}{ }^{1}$ \\
\hline $457+50$ & 178.7 & 166 & 6 & 1.0 & 1.0 & 1.1 & 0.15 & 7.7 & 12.7 & 21 & 3.1 & 158 \\
$459+10$ & 178.7 & 170 & 6 & 1.0 & 1.0 & 1.1 & .19 & 7.2 & 8.4 & 20 & 3.1 & 163 \\
$460+65$ & 178.7 & 165 & 6 & 1.0 & 1.0 & 1.1 & .15 & 7.7 & 13.7 & 21 & 3.1 & 157 \\
$463+05$ & 178.7 & 130 & 6 & 1.0 & 1.0 & 1.1 & .17 & 12.9 & 48.7 & 35 & 6.8 & 117 \\
$465+80$ & 178.7 & 129 & 6 & 1.0 & 1.0 & 1.1 & .17 & 12.9 & 49.7 & 36 & 6.8 & 116 \\
$468+20$ & 178.7 & 151 & 6 & 1.0 & 1.0 & 1.1 & .29 & 13.2 & 27.7 & 36 & 8.6 & 138 \\
$469+85$ & 178.7 & 148 & 6 & 1.0 & 1.0 & 1.1 & .17 & 10.8 & 30.7 & 30 & 5.2 & 137 \\
$471+50$ & 178.7 & 147 & 6 & 1.0 & 1.0 & 1.1 & .15 & 10.5 & 31.7 & 29 & 4.8 & 137 \\
$473+15$ & 178.7 & 160 & 6 & 1.0 & 1.0 & 1.1 & .17 & 9.2 & 18.7 & 25 & 4.2 & 151 \\
$474+80$ & 178.7 & 159 & 6 & 1.0 & 1.0 & 1.1 & .15 & 8.8 & 19.7 & 24 & 3.7 & 150 \\
\hline
\end{tabular}

${ }^{1}$ Numbers are rounded to the nearest foot.

Pier Scour

For evaluation of pier scour at Interstate Hwy. 220, values for $y_{1}$ at each pier were based on the DOTD hydrographic survey of 1991 . The cross section represented by this survey represents a fairly uniform section (fig. 36). Other surveys at this site indicate little movement of the thalweg. Values for $\mathrm{K}_{1}=1.0, \mathrm{~K}_{2}=1.0$, and $\mathrm{K}_{3}=1.1$ were based on DOTD bridge plans and recommendations presented by Richardson and others (1993, p. 39-40). The Froude number at the pier location is based upon the value of velocity, which was computed using WSPRO.

The maximum computed scour depth was about $13.2 \mathrm{ft}$ for the pier at DOTD station $468+20$ (table 9). The minimum channel-bed elevation of the computed scour hole at DOTD station $465+80$ is about $116 \mathrm{ft}$ above sea level. The elevation of the top of the footing for this pier is about $102 \mathrm{ft}$ above sea level. 


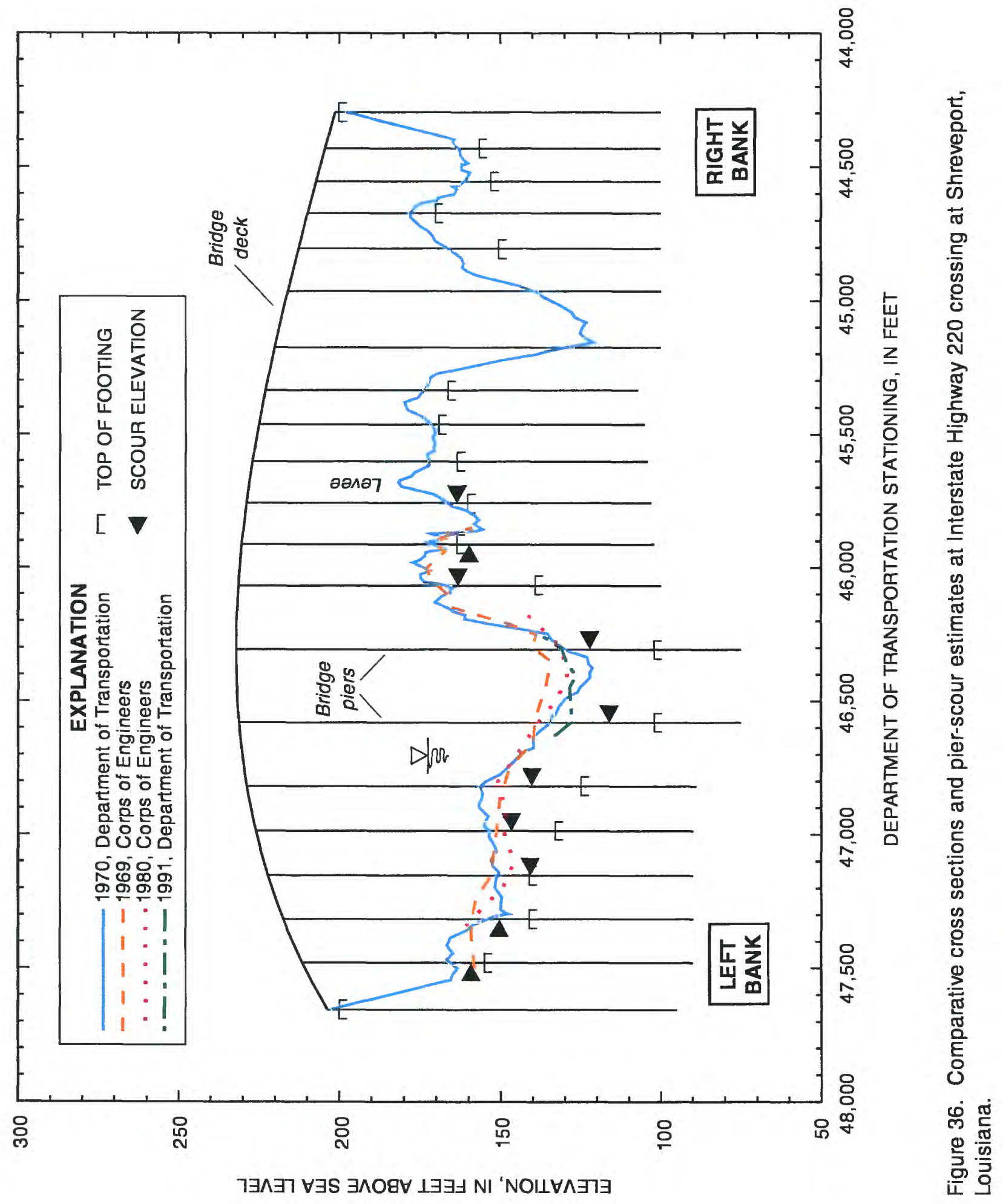




\section{Channel Stability}

Cross-section information exists for the years 1969, 1970, 1980, and 1991. The elevation of the thalweg changes about $10 \mathrm{ft}$ among the surveys. Indication of any lateral movement or shifting of the channel is not significant based on the survey information. Some of the variation in channel-bed elevations may be the response of the stream bed to seasonal variations in discharge. The right bank is the steepest of the two stream banks, and is the outside bank of the curve in the river to the left. Although this bank is relatively steeply sloping, and is the outside bank of a curve, the cross-section information indicates that it is stable and shows no erosion. Figures 37 and 38 are aerial photographs of the bridge crossing for 1977 and 1987. Timber river-training works are visible on the right bank in the photographs. This timber piling may have contributed to the stability of the right bank.

\section{Louisiana Highway 2 near Hosston, Louisiana}

Flood-frequency estimates based on the regression shown in figure 7 were used for the hydraulir analysis. The 500-year flood estimate is $386,700 \mathrm{ft}^{3} / \mathrm{s}$ (table 1). Hydraulic simulations were calibrated to a historic discharge of $214,000 \mathrm{ft}^{3} / \mathrm{s}$, with a water-surface elevation of $189.5 \mathrm{ft}$ above sea level. The computed water-surface elevation resulting from hydraulic simulations using the 500 -year flood estimate was $198.6 \mathrm{ft}$ above sea level (table 10). The model reach for evaluation of the La. Hwy. 2 bridge extends from about $4,000 \mathrm{ft}$ downstream to $500 \mathrm{ft}$ upstream of the highway crossing. The width of the channel at the 500 -year flood estimate ranges from 2,700 to $4,500 \mathrm{ft}$ throughout the reach. The minimum channel-bed elevations for cross sections in the reach ranged from 140 to $160 \mathrm{ft}$ above sea level. The downstream starting elevation for computations using WSPRO was a slope of $0.0002 \mathrm{ft} / \mathrm{ft}$, which is the same slope used in the calibration simulations. Simulations indicate velocities ranging from 3.8 to $8.6 \mathrm{ft} / \mathrm{s}$ along the cross section at the bridge (table 10).

Table 10. Pier-scour estimates for Louisiana Highway 2 crossing the Red River near Hosston, Louisiana

[DOTD, Louisiana Department of Transportation and Development; WSE, water-surface elevation, in feet above sea level; GSE: ground-surface (channel-bed) elevation, in feet above sea level; a, width of pier, in feet; $\mathrm{K}_{1}$, dimensionless correction factor for pier nose shape; $K_{2}$, dimensionless correction factor for angle of flow attack; $K_{3}$, dimensionless correction factor for channel-bed condition; $\mathrm{Fr}$, Froude number computed at the location; $y_{S}$, estimated depth of pier scour, in feet; $y_{1}$, flow depth directly upstream of the pier, in feet; $T w$, estimated top width of the scour hole, in feet; $V$, velocity computed for that location in the cross section, in feet per second; $y_{d}$, channel-bed elevation of the computed scour hole, in feet above sea level]

\begin{tabular}{|c|c|c|c|c|c|c|c|c|c|c|c|c|}
\hline $\begin{array}{l}\text { DOTD } \\
\text { station }\end{array}$ & WSE & GSE & a & $\mathbf{K}_{1}$ & $\mathbf{K}_{2}$ & $\mathbf{K}_{3}$ & $\mathrm{Fr}$ & $\mathbf{y}_{\mathrm{S}}$ & $y_{1}$ & Tw & $\mathbf{v}$ & $y_{d}{ }^{1}$ \\
\hline $304+34$ & 198.6 & 175 & 13 & 1.0 & 1.0 & 1.1 & 0.14 & 13.7 & 23.6 & 38 & 3.8 & 161 \\
\hline $308+00$ & 198.6 & 143 & 13 & 1.0 & 1.0 & 1.1 & .18 & 20.8 & 55.6 & 57 & 7.7 & 122 \\
\hline $311+65$ & 198.6 & 170 & 13 & 1.0 & 1.0 & 1.1 & .28 & 19.9 & 28.6 & 55 & 8.6 & 150 \\
\hline $315+30$ & 198.6 & 168 & 13 & 1.0 & 1.0 & 1.1 & .24 & 19.1 & 30.6 & 52 & 7.6 & 149 \\
\hline $318+93$ & 198.6 & 178 & 13 & 1.0 & 1.0 & 1.1 & .15 & 13.6 & 20.6 & 37 & 3.9 & 164 \\
\hline \multicolumn{13}{|c|}{$\underline{\text { Left overbank piers }}$} \\
\hline $\begin{array}{l}\text { Landward } \\
\text { of } \\
319+00\end{array}$ & 198.6 & 172 & 13 & 1.0 & 1.0 & 1.1 & .10 & 12.4 & 26.6 & 34 & 2.9 & 160 \\
\hline
\end{tabular}

\footnotetext{
${ }^{1}$ Numbers are rounded to the nearest foot.
} 


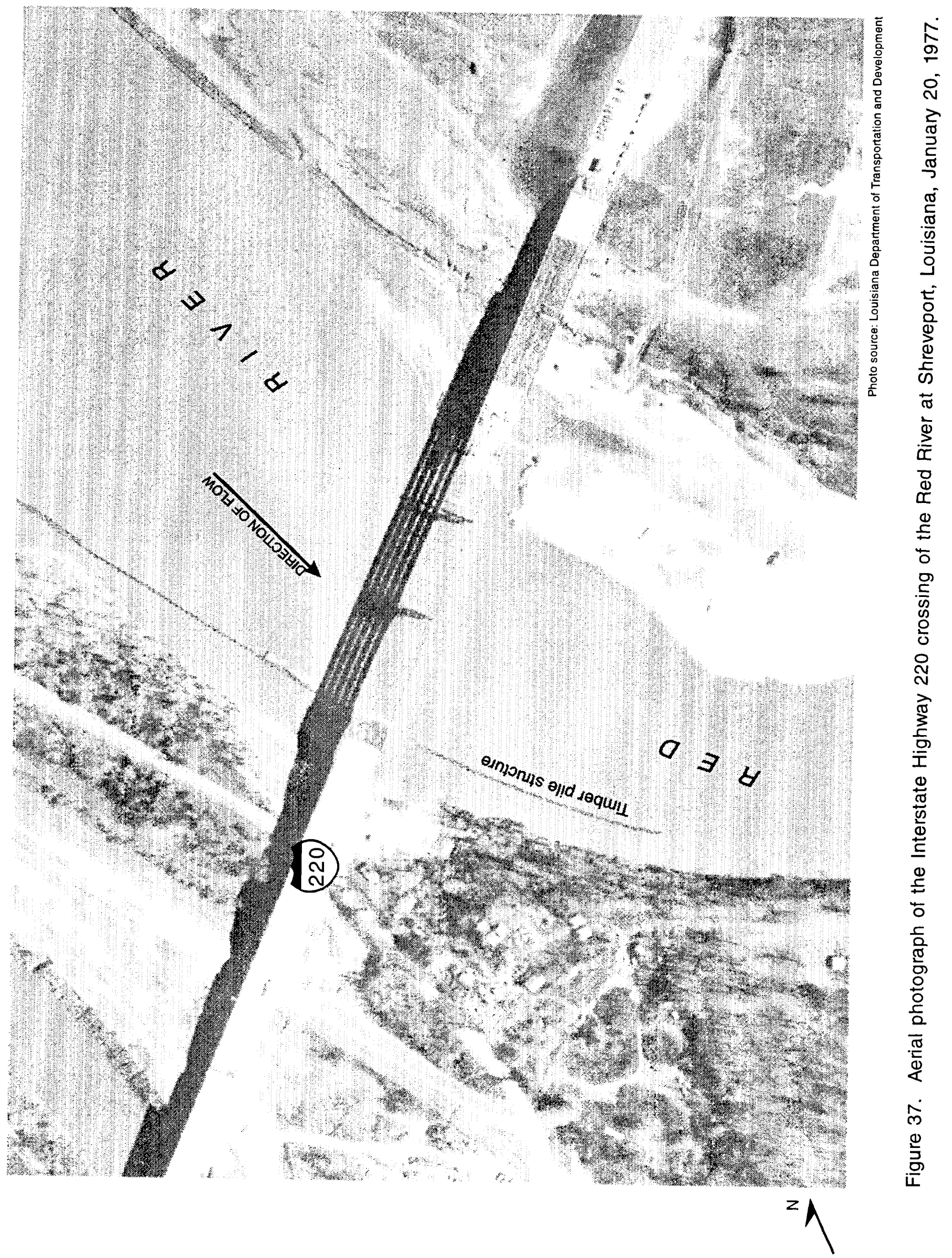




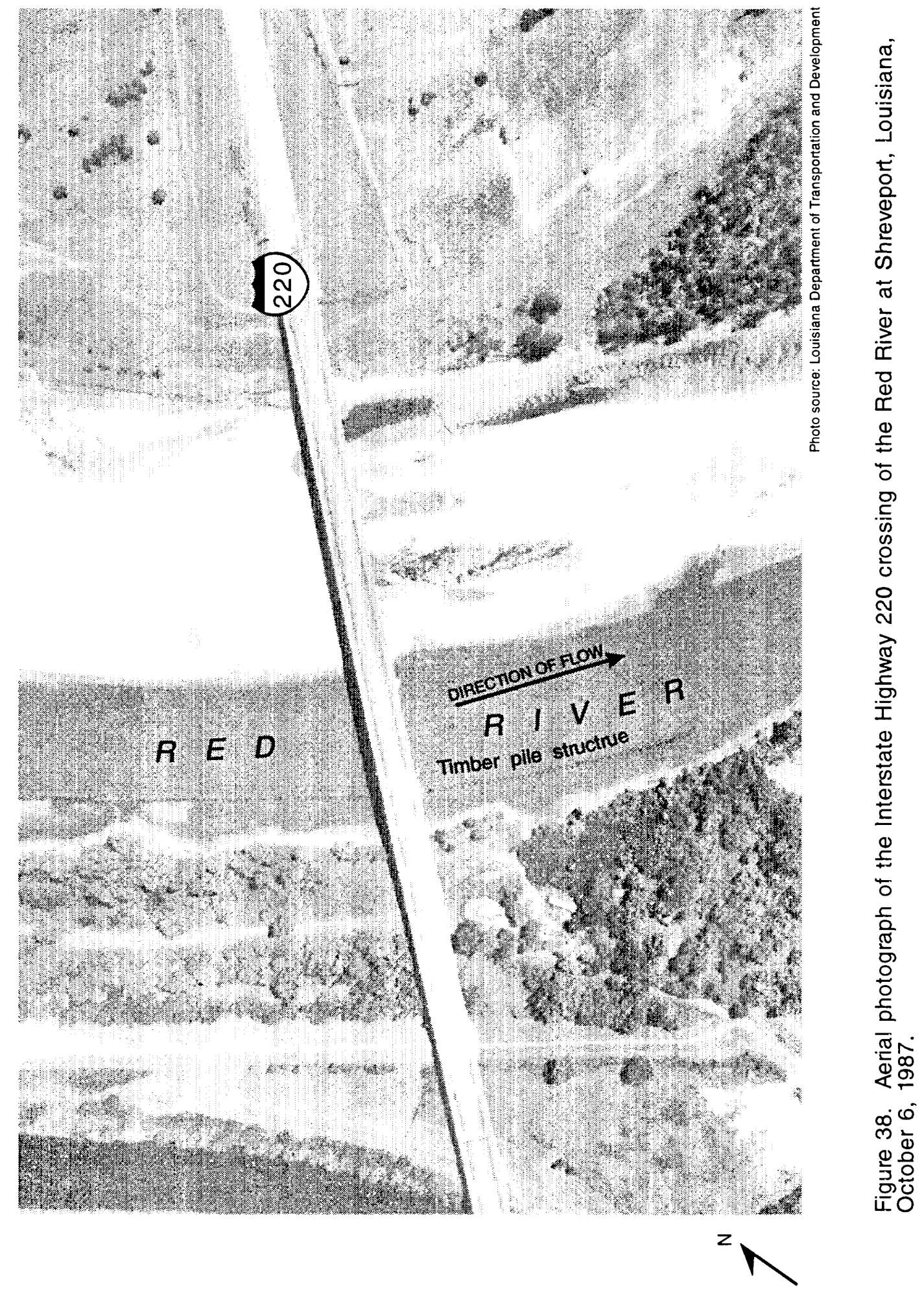




\section{Pier Scour}

For evaluation of pier scour at La. Hwy. 2, values for $y_{1}$ at each pier were based on the COE hydrographic survey of 1980 . The cross section represented by this survey is the most recent bank to bank survey. Other surveys at this site indicate considerable movement of the thalweg. Values for $\mathrm{K}_{1}=1$.C. $\mathrm{K}_{2}=1.0$, and $\mathrm{K}_{3}=1.1$ were based on DOTD bridge plans and recommendations presented by Richardson and others (1993, p. 39-40). The Froude number at the pier location is based upon the value of velocity, which was computed using WSPRO.

The maximum computed scour depth was approximately $20.8 \mathrm{ft}$ for the pier at DOTD station 308+0? (table 10). The channel-bed elevation of the computed scour hole is about $122 \mathrm{ft}$ above sea level. The elevation of the pile-footing cap for this pier is about $125 \mathrm{ft}$ above sea level. Potential scour for the piers $c^{*}$ DOTD stations 304+34 and 308+00 may approach the maximum computed scour for this bridge. Although this depth of scour is greater than indicated from the computations shown for DOTD station 304+34, it should be considered because of the observed shifting of the channel at this bridge. For piers landward $c^{f}$ DOTD station $319+00$, the estimated depth of scour is $12.4 \mathrm{ft}$ (fig. 39, table 10).

\section{Channel Stability}

Cross-section information is shown in figure 39 for the years 1951, 1969, and 1980. These surveys indicate significant dynamic activity of the channel bed at this location. It should be noted that, although prominent bed activity is documented among the surveys, similar activity could have occurred between the surveys. Of all the surveys shown in figure 39 , no two surveys replicate each other in any reasonable manner. Surveys not shown in figure 39 for the purpose of clarity show the thalweg on the left bank in 1949, shifted toward the right bank in 1950, then further to the right in 1951. The 1969 survey documents that the thalweg had moved near center channel and a relatively uniform cross section existed. The survey of 198 ? documents movement toward the right bank again, near the observed location of the thalweg in 1950. All of the thalweg elevations observed near the right bank were about $140 \mathrm{ft}$ above sea level, which is about 15 $\mathrm{ft}$ above the pile-footing cap for the bridge-support piers. A comparison of aerial photographs taken in 1977 and 1987 (figs. 40 and 41 ) shows the main channel is on the right side of the river during low water. It can also be observed that, during this time period between the two photographs, vegetation has become more established in the area separating the main channel and the minor channel on the left bank.

\section{CONCLUSIONS}

Bridge sites examined in this investigation ranged in location along the Red River from river mile 67, La. Hwy. 107 near Moncla, to river mile 318, La. Hwy. 2, near Hosston. The value for the 500-year flood estimates computed for three gaging stations along the reach. The discharge through the reach ranged from 249,700 to 386,700 cubic feet per second. The water-surface elevations associated with the 500-year flood estimates ranged from 71.1 to 198.6 feet above sea level. Main channel widths at the 13 sites ranged from 500 to 1,350 feet, and flood plain widths ranged from 800 to 3,000 feet. The river is confined by levees throughout the study reach, and bridge approaches generally originate landward of the levee, so contraction and abutment scour computations were not applicable. 


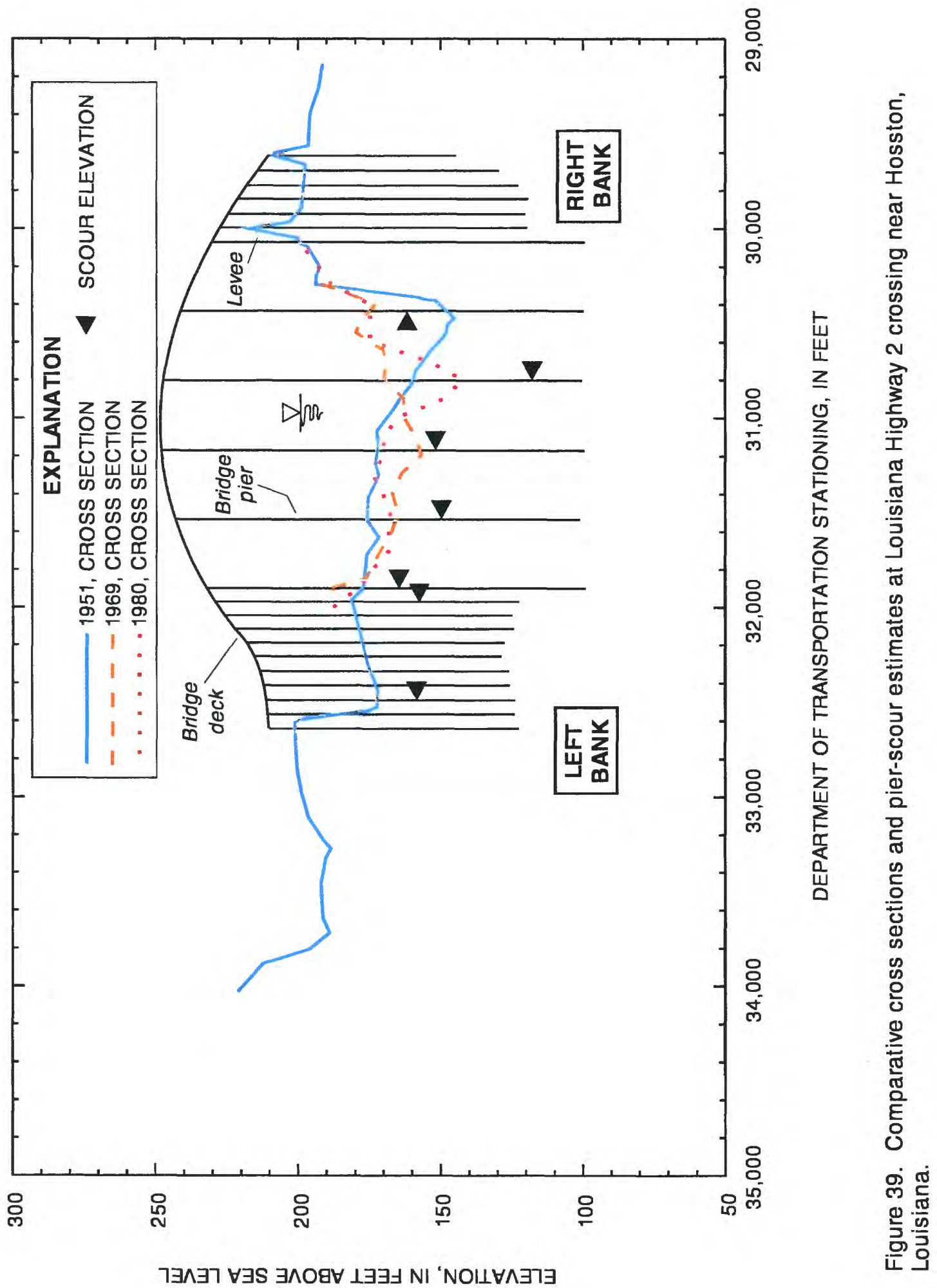




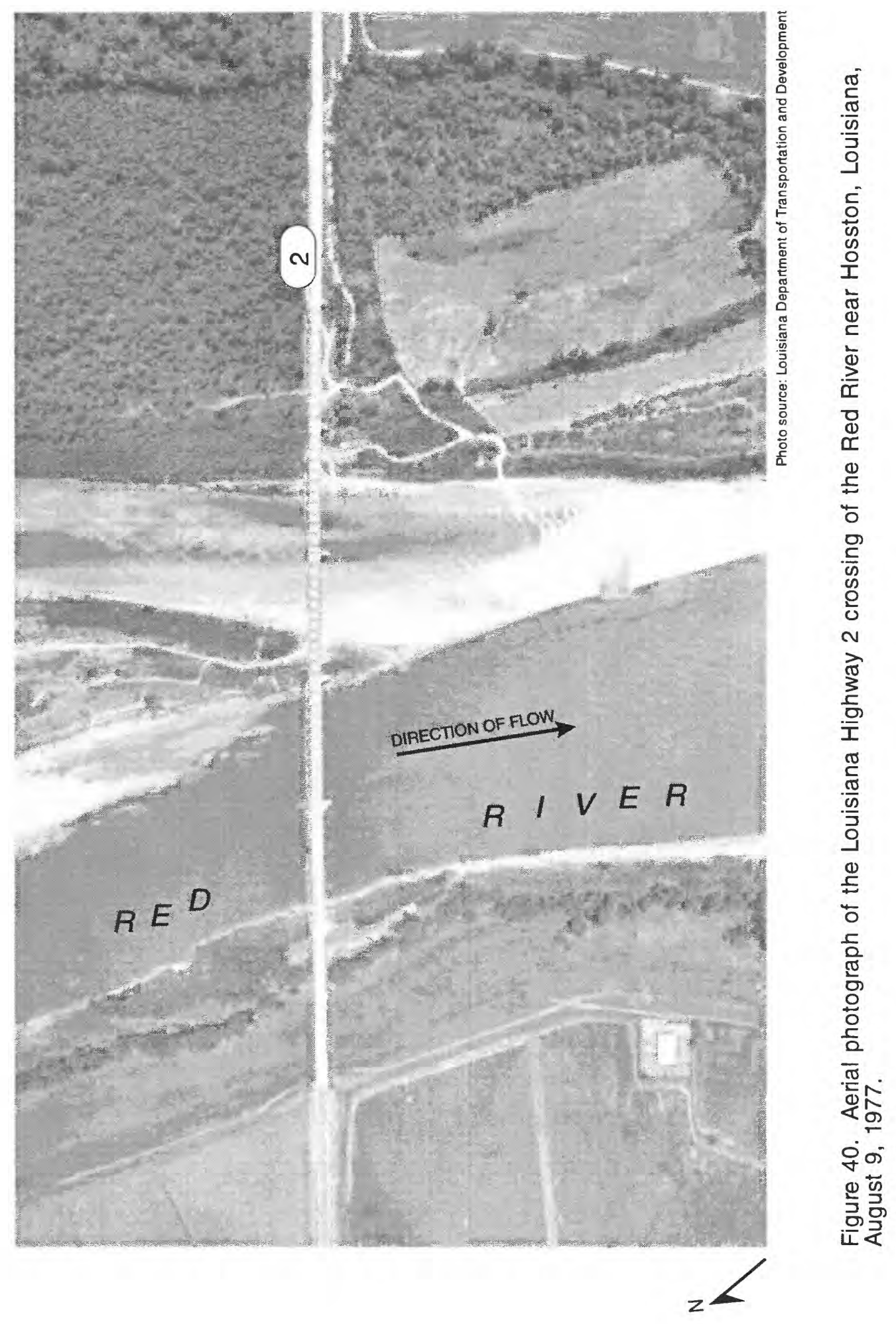




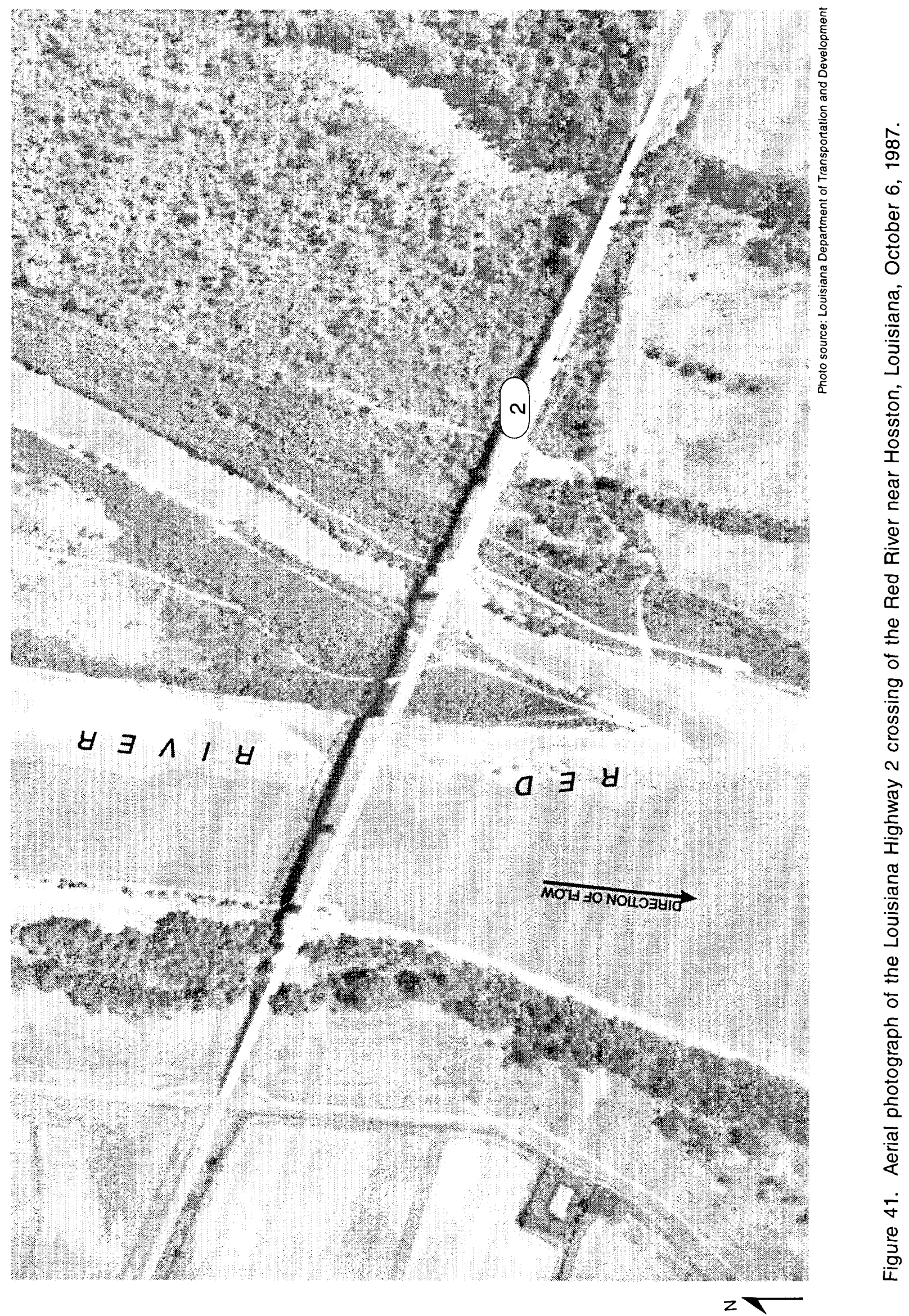


To determine values for the hydraulic variables that are used in the pier-scour equation, the Water Surface Profile model, WSPRO, was calibrated to historic data along the river. Downstream boundar' conditions were established by a water-surface specification for one site, and by a water-surface slope at all others. Values for the velocity at each pier were established from partitioning the flow along the cross section. Roughness coefficients used in the hydraulic simulations ranged from 0.025 to 0.035 in the channels to 0.06 to 0.08 in the overbanks. The calibrated model was then used to simulate the hydraulic conditions associated with the 500-year flood estimates.

The Colorado State University pier-scour equation presented in HEC-18 were applied to estimate the amount of scour that could occur during a 500-year flood estimate. Scour depths estimated at piers ranged from approximately 3.0 feet on the overbank at La. Hwy. 3032 to approximately 47 feet for a main channel pier on U.S. Hwy. 167. At La. Hwy. 8 where piers are protected by riprap, a scour estimate was computed but was not relevant. Periodic monitoring of the elevation of the riprap has indicated that the riprap has stabilized the channel bed.

The channel was most dynamic at La. Hwy. 2, where periodic surveys indicated a shifting thalweg. The site with the most physical evidence of pier scour was La. Hwy. 3032. Scour holes were also measuret at this site during the 1990 high flow event, which are comparable in magnitude to the estimated scour depths.

\section{SELECTED REFERENCES}

Biedenharn, D.S., Combs, P.G., Hill, G.J., Pinkard, C.F., Jr., and Pinkston, C.B., 1989, Relationship between channel migration and radius of curvature on the Red River, in Wang, S.S.Y., ed., 1989, Sediment Transport Modeling--Proceedings of the International Symposium (New Orleans, La., Aug. 14-18, 1989), New York, American Society of Civil Engineers, p. 536-541.

Lagasse, P.F., Schall, J.D., Johnson, F., Richardson, E.V., Richardson, J.R., Chang, F., 1991, Stream stability at highway structures: U.S. Department of Transportation, Federal Highway Administration, FHWA-IP-90-014, Hydraulic Engineering Circular no. 20, 195 p.

Nanson, G.C., and Hickin, E.J., 1986, A statistical analysis of bank erosion and channel migration in Western Canada: Geological Society of America, Bulletin 97, p. 497-504.

Neill, C.R., and Yaremko, E.K., 1989, Identifying causes and predicting effects of bank erosion, in Ports, M.A., ed., Hydraulic Engineering: Proceedings of the 1989 National Conference on Hydraulic Engineering (New Orleans, La., Aug. 14-18, 1989), New York, American Society of Civil Engineers, p. 101-105.

Richardson, E.V., Harrison, L.J., and Davis, S.R., 1991, Evaluating scour at bridges: U.S. Department of Transportation, Federal Highway Administration, FHWA-IP-90-017, Hydraulic Engineering Circular no. 18, 105 p.

Richardson, E.V., Harrison, L.J., Richardson, J.R, and Davis, S.R., 1993 (revised), Evaluating scour at bridges: U.S. Department of Transportation, Federal Highway Administration, FHWA-IP-90-017, Hydraulic Engineerirg Circular no. $18,105 \mathrm{p}$.

Shearman, J.O., Kirby, W.H., Schneider, V.R., and Flippo, H.N., Bridge waterways analysis: U.S. Department of Transportation, Federal Highway Administration, Research Report, FHWA-RD-86-108, 112 p.

Thorne, C.R., 1989, Bank processes on the Red River between Index, Arkansas, and Shreveport, Louisiana, Preliminary draft of final technical report to European Research Office of U.S. Army, London, England.

U.S. Geological Survey, 1982, Guidelines for determining flood flow frequency: Reston, Va., Office of Water Data Coordination, Interagency Advisory Committee on Water Data, Bulletin 17B of the Hydrology Subcommittes, $162 \mathrm{p}$. 